\title{
First-Principles Modeling of Hydrogen Storage in Metal Hydride Systems
}

\author{
J. Karl Johnson, University of Pittsburgh \\ David S. Sholl, Georgia Tech
}

Final Report

May 2011

\section{Executive Summary}

The objective of this project is to complement experimental efforts of MHoCE partners by using state-of-the-art theory and modeling to study the structure, thermodynamics, and kinetics of hydrogen storage materials. Specific goals include prediction of the heats of formation and other thermodynamic properties of alloys from first principles methods, identification of new alloys that can be tested experimentally, calculation of surface and energetic properties of nanoparticles, and calculation of kinetics involved with hydrogenation and dehydrogenation processes. Discovery of new metal hydrides with enhanced properties compared with existing materials is a critical need for the Metal Hydride Center of Excellence. New materials discovery can be aided by the use of first principles (ab initio) computational modeling in two ways: (1) The properties, including mechanisms, of existing materials can be better elucidated through a combined modeling/experimental approach. (2) The thermodynamic properties of novel materials that have not been made can, in many cases, be quickly screened with ab initio methods. We have used state-of-the-art computational techniques to explore millions of possible reaction conditions consisting of different element spaces, compositions, and temperatures. We have identified potentially promising single- and multi-step reactions that can be explored experimentally.

\section{Introduction}

Complex metal hydrides have been extensively studied as candidate materials for hydrogen storage in vehicular and other applications. ${ }^{1-9}$ An important focus in this field has been to find complex metal hydride mixtures having thermodynamics that make using them under

moderate temperatures and pressures feasible. ${ }^{5,6,10-12}$ Controlling the reaction thermodynamics of complex metal hydrides via so-called destabilization reactions is one example of this kind. ${ }^{4,13-15}$ Vajo et al. reported that $\mathrm{LiBH}_{4}$ is destabilized by $\mathrm{MgH}_{2},{ }^{4}$ and subsequent experiments showed that $\mathrm{LiBH}_{4}$ can also be destabilized by $\mathrm{CaH}_{2} \cdot{ }^{14}$ Although experiments are the final arbiter of a reaction's usefulness, it is not practical to systematically study every conceivable reaction mixture experimentally. Therefore, systematic thermodynamic calculations based on firstprinciples calculations have played a useful role in the search for desirable reaction mixtures. First-principles calculations have been shown to yield reaction free energies that are accurate within $\pm 10 \mathrm{~kJ} / \mathrm{mol} \mathrm{H}_{2}-$ a level of precision that is adequate for screening large numbers of 
potentially interesting reactions. ${ }^{16-18}$

Several earlier efforts have been made to categorize metal hydride mixtures using the thermodynamic calculations based on density functional theory (DFT) calculations and a database of crystal compounds. ${ }^{19-24}$ The methodological basis of these calculations is the grand canonical linear programming method introduced by Ozolins and co-workers. ${ }^{19-22,24}$ This approach rigorously determines the thermodynamic state of a specified set of elements among a set of crystalline materials in equilibrium with gaseous $\mathrm{H}_{2}$, subject to a number of caveats. Ozolins et al. systematically predicted the thermodynamics of possible metal hydride mixtures in the Li-Mg-Ca-B-H system using this method. ${ }^{22}$ The same group has reported results for the Li-BN-H, Li-Mg-N-H and Li-Mg-Al-H systems. ${ }^{19-21,24}$ Calculations that explored a wider range of elements were performed by Alapati, Johnson, and Sholl, who analyzed the 715 four-element spaces available from thirteen solid elements plus $\mathrm{H}$ with the same method. ${ }^{23}$ Alapati et al. performed calculations based on $0 \mathrm{~K}$ reaction enthalpies predicted by DFT, an approach that requires much less computational effort for each solid than the free energy calculations used by Ozolins et al. This approach allowed Alapati et al. to screen a much larger element and composition space than previously examined with an uncertainty of about $\pm 15 \mathrm{~kJ} / \mathrm{mol} \mathrm{H}_{2}$. The 0 $\mathrm{K}$ approximation inherent in this approach can readily be removed for the most promising reactions by computing the DFT-based free energies of the solids involved in these reactions. ${ }^{16-}$ 18,23

A key limitation of the linear programming approach is that it cannot make predictions about reactions that involve compounds that are not included in the database of materials used for the calculations. Because of the large amount of research that has been performed on metal hydrides and related materials in recent years, the studies cited above were based on databases that did not include many materials that have been characterized in more recent experiments. For example, the earlier work of Alapati et al. did not include the metal closoboranes $\left(\mathrm{M}_{\mathrm{n}} \mathrm{B}_{12} \mathrm{H}_{12}\right.$, for $\mathrm{M}=\mathrm{Li}, \mathrm{Mg}, \mathrm{Ca}$, or $\mathrm{K}$ ), which since that time have been observed or predicted as intermediates in the decomposition reactions of the metal borohydrides. ${ }^{22,25-29}$ One aim of the present work is to update the extensive calculations of Alapati et al. using a database of materials that includes a large number of these recently described compounds. Specifically, we performed the necessary DFT calculations to add 147 new crystalline compounds (including but not limited to $\mathrm{B}_{12} \mathrm{H}_{12-}$ based materials) to the 212 materials that were used earlier by Alapati et al. We then analyzed the reactions thermodynamics for all reaction mixtures defined by the 715 four-element spaces mentioned above.

The earlier work of Alapati et al. categorized the large number of distinct reactions that can occur for mixtures involving metal hydrides by focusing exclusively on reactions that occur in a single step. However, there are well known examples of multi-step reactions that have properties that are interesting in $\mathrm{H}_{2}$ storage applications that are not captured if one focuses solely on single step reactions. A second aim of our work is to analyze the large number of reactive mixtures listed above to identify multi-step reactions with useful thermodynamic properties. 


\section{Approach}

All DFT calculations were performed with methods that are consistent with the earlier calculations of Alapati et al. ${ }^{16-18,23,30}$ These DFT calculations used the Vienna ab initio Simulation Package (VASP) with the PW91 generalized gradient approximation (GGA) functional. ${ }^{31-34}$ The projector augmented wave (PAW) method was used for describing the core electrons of each atom. ${ }^{35}$ An energy cutoff of $425 \mathrm{eV}$ was used for all calculations. Geometries were relaxed until the forces on all atoms were less than $0.03 \mathrm{eV} / \AA$. Structural optimizations of all new crystal compounds in our database were performed by the conjugate gradient method. Calculations of compounds having cubic unit cells were performed with a Monkhorst-Pack mesh of $9 \times 9 \times 9$ or $8 \times 8 \times 8 k$-points. A smaller number of $k$-points were used for a few systems having the largest unit cells. The numbers of $k$-points for compounds having the non-cubic unit cells were determined by considering the shape of the unit cells so that the density of $k$-points in reciprocal space was similar to the value for materials with cubic unit cells.

We used a single unit cell to optimize the bulk crystal structure of each compound listed in Table 1. In general, the initial structures for geometry relaxations were obtained from the experimental data available from ICSD. ${ }^{36}$ Optimization of $\mathrm{Li}_{2} \mathrm{~B}_{12} \mathrm{H}_{12}$ and $\mathrm{MgB}_{12} \mathrm{H}_{12}$ were started from the structures observed by Her et al. ${ }^{25}$ and predicted by Ozolins et al., ${ }^{22}$ respectively. One heuristic way to examine the reliability of our optimized structures is to compare the volume of the optimized structure with the experimental volume. As expected, the agreement between the experimentally observed and DFT optimized volumes is in general very good. There are two compounds where the experimental and DFT optimized volumes differ by more than $10 \%$ : $\mathrm{Si}_{2} \mathrm{C}_{7} \mathrm{H}_{18} \mathrm{~N}_{2}$ (14\% error) and $\mathrm{Ti}_{2} \mathrm{AlC}$ (11\% error). It is not clear what the source of these relatively large discrepancies is.

For two reactions described below we computed the VDOS of every solid compound in order to compute the reaction free energy. For these VDOS calculations, we used the PHONON code developed by Parlinski. ${ }^{37}$

Table 1: List of the 147 crystalline compounds whose total energies were calculated with DFT in this work.

\section{Two-element compounds}

\begin{tabular}{|l|l|l|l|l|}
\hline $\mathrm{AlB}_{12}$ & $\mathrm{Al}_{4} \mathrm{C}_{3}$ & $\mathrm{Al}_{4} \mathrm{Ca}$ & $\mathrm{Al}_{14} \mathrm{Mg}_{13}$ & $\mathrm{Al}_{30} \mathrm{Mg}_{23}$ \\
\hline $\mathrm{Al}_{23} \mathrm{~V}_{4}$ & $\mathrm{Al}_{45} \mathrm{~V}_{7}$ & $\mathrm{~B}_{4} \mathrm{C}$ & $\mathrm{B}_{13} \mathrm{C}_{2}$ & $\left(\mathrm{~B}_{10} \mathrm{H}_{13}\right)_{2}$ \\
\hline $\mathrm{B}_{13} \mathrm{~N}_{2}$ & $\mathrm{C}_{2} \mathrm{Ca}$ & $\mathrm{C}_{2} \mathrm{~N}_{2}$ & $\mathrm{C}_{3} \mathrm{~N}_{4}$ & $\mathrm{C}_{5} \mathrm{~N}_{4}$ \\
\hline $\mathrm{C}_{12} \mathrm{~N}_{6}$ & $\mathrm{CaB}_{4}$ & $\mathrm{Ca}_{2} \mathrm{Si}$ & $\mathrm{KC}_{8}$ & $\mathrm{KSi}$ \\
\hline $\mathrm{K}_{8} \mathrm{Si}_{46}$ & $\mathrm{LiB}$ & $\mathrm{LiMg}$ & $\mathrm{Li}_{12} \mathrm{Si}_{7}$ & $\mathrm{Li}_{13} \mathrm{Si}_{4}$ \\
\hline $\mathrm{Li}_{15} \mathrm{Si}_{4}$ & $\mathrm{NaB}_{15}$ & $\mathrm{Na}_{3} \mathrm{~B}_{20}$ & $\mathrm{Na}_{4} \mathrm{Si}_{4}$ & $\mathrm{Na}_{8} \mathrm{Si}_{46}$ \\
\hline $\mathrm{Sc}_{15} \mathrm{C}_{19}$ & $\mathrm{SiB}_{3}$ & $\mathrm{SiC}$ & $\mathrm{TiV}$ & $\mathrm{V}_{2} \mathrm{~N}$ \\
\hline $\mathrm{V}_{5} \mathrm{Si}_{3}$ & \multicolumn{5}{|l|}{} \\
\hline Three-element compounds & $\mathrm{Cl}_{2} \mathrm{MgC}_{2}$ & $\mathrm{Al}_{18} \mathrm{Mg}_{3} \mathrm{Ti}_{2}$ & $\mathrm{BC}_{2} \mathrm{~N}$ & \\
\hline $\mathrm{Al}\left(\mathrm{BH}_{4}\right)_{3}$ & \multicolumn{5}{|l}{} \\
\hline
\end{tabular}




\begin{tabular}{|c|c|c|c|c|}
\hline $\mathrm{C}_{2} \mathrm{H}_{18} \mathrm{~N}_{18}$ & $\mathrm{C}_{2} \mathrm{~N}_{2}(\mathrm{NH})$ & $\mathrm{Ca}_{4} \mathrm{Al}_{3} \mathrm{Mg}$ & CaAlSi & $\mathrm{Ca}\left(\mathrm{BH}_{4}\right)_{2}$ \\
\hline $\mathrm{CaB}_{12} \mathrm{H}_{12}$ & $\mathrm{CaC}_{4} \mathrm{~N}_{6}$ & $\mathrm{Ca}_{4} \mathrm{~N}_{2}\left(\mathrm{CN}_{2}\right)$ & $\mathrm{Ca}_{11} \mathrm{~N}_{6}\left(\mathrm{CN}_{2}\right)_{2}$ & $\mathrm{CaSiN}_{2}$ \\
\hline $\mathrm{Ca}_{2} \mathrm{Si}_{5} \mathrm{~N}_{8}$ & $\mathrm{Ca}_{5}\left(\mathrm{Si}_{2} \mathrm{~N}_{6}\right)$ & $\mathrm{Ca}_{4} \mathrm{TiN}_{4}$ & $\mathrm{H}_{9} \mathrm{CN}_{9}$ & $\mathrm{KBH}_{4}$ \\
\hline $\mathrm{KB}_{21} \mathrm{H}_{18}$ & $\mathrm{~K}_{2} \mathrm{~B}_{6} \mathrm{H}_{6}$ & $\mathrm{~K}_{2}\left(\mathrm{~B}_{10} \mathrm{H}_{10}\right)$ & $\mathrm{K}_{2} \mathrm{~B}_{12} \mathrm{H}_{12}$ & $\mathrm{KC}_{4} \mathrm{~N}_{3}$ \\
\hline $\mathrm{KNH}_{2}$ & $\left(\mathrm{~K}\left(\mathrm{NH}_{2}\right)\right)\left(\mathrm{NH}_{3}\right)_{2}$ & $\mathrm{LiAlB}_{14}$ & $\mathrm{LiB}_{13} \mathrm{C}_{2}$ & $\mathrm{Li}_{2} \mathrm{~B}_{12} \mathrm{C}_{2}$ \\
\hline $\mathrm{LiBH}$ & $\mathrm{Li}\left(\mathrm{BH}_{2}\right)$ & $\mathrm{Li}_{2} \mathrm{~B}_{12} \mathrm{H}_{12}$ & $\mathrm{Li}_{3}\left(\mathrm{BH}_{6}\right)$ & $\mathrm{Li}_{2} \mathrm{~B}_{12} \mathrm{Si}_{2}$ \\
\hline $\mathrm{LiMgH}_{3}$ & $\mathrm{Li}_{2} \mathrm{MgSi}$ & $\mathrm{LiN}_{3} \mathrm{Si}_{2}$ & $\mathrm{LiNa}_{2} \mathrm{~N}$ & $\mathrm{LiNa}_{5} \mathrm{~N}_{2}$ \\
\hline $\mathrm{Li}_{2} \mathrm{Na}_{4} \mathrm{~N}_{2}$ & $\mathrm{Li}_{2} \mathrm{NaN}$ & $\mathrm{Li}_{3} \mathrm{Na}_{3} \mathrm{~N}_{2}$ & $\mathrm{Li}_{4} \mathrm{Na}_{2} \mathrm{~N}_{2}$ & $\mathrm{Li}_{5} \mathrm{NaN}_{2}$ \\
\hline $\mathrm{Li}_{3} \mathrm{NaSi}_{6}$ & $\mathrm{MgAl}_{2} \mathrm{Si}_{2}$ & $\mathrm{MgB}_{12} \mathrm{C}_{2}$ & $\mathrm{Mg}_{2} \mathrm{~B}_{24} \mathrm{C}$ & $\mathrm{MgB}_{12} \mathrm{H}_{12}$ \\
\hline $\mathrm{MgB}_{12} \mathrm{Si}_{2}$ & $\mathrm{MgC}_{4} \mathrm{~N}_{6}$ & $\mathrm{Mg}_{7} \mathrm{TiH}_{16}$ & $\mathrm{~N}_{2} \mathrm{BH}_{7}$ & $\mathrm{~N}_{2} \mathrm{~B}_{10} \mathrm{H}_{18}$ \\
\hline $\mathrm{N}_{3} \mathrm{~B}_{3} \mathrm{H}_{6}$ & $\mathrm{~N}_{3} \mathrm{~B}_{3} \mathrm{H}_{12}$ & $\mathrm{~N}_{4} \mathrm{~B}_{9} \mathrm{H}_{11}$ & $\mathrm{~N}_{4} \mathrm{~B}_{10} \mathrm{H}_{8}$ & $\mathrm{~N}_{4} \mathrm{~B}_{10} \mathrm{H}_{22}$ \\
\hline $\mathrm{NH}_{3} \mathrm{BH}_{3}$ & $\left(\mathrm{NH}_{4}\right)_{2} \mathrm{~B}_{12} \mathrm{H}_{12}$ & $\left(\mathrm{NH}_{2}\right) \mathrm{CN}$ & $\mathrm{NH}_{4} \mathrm{HCN}_{2}$ & $\mathrm{Na}_{5} \mathrm{Al}_{3} \mathrm{H}_{14}$ \\
\hline $\mathrm{NaBH}_{4}$ & $\mathrm{Na}_{2}\left(\mathrm{~B}_{10} \mathrm{H}_{10}\right)$ & $\mathrm{Na}_{3}\left(\mathrm{BN}_{2}\right)$ & $\mathrm{Na}_{3} \mathrm{C}_{6} \mathrm{~N}_{9}$ & $\mathrm{Sc}_{2} \mathrm{AlC}$ \\
\hline $\mathrm{Ti}_{2} \mathrm{AlC}$ & $\mathrm{Ti}_{6} \mathrm{Si}_{2} \mathrm{~B}$ & $\mathrm{~V}_{12} \mathrm{Al}_{3} \mathrm{C}_{8}$ & $\mathrm{~V}_{5} \mathrm{SiB}_{2}$ & \\
\hline \multicolumn{5}{|c|}{ Four-element compounds } \\
\hline $\mathrm{AlNC}_{3} \mathrm{H}_{10}$ & $\mathrm{BCH}_{5} \mathrm{~N}_{2}$ & $\mathrm{~B}_{10} \mathrm{C}_{6} \mathrm{H}_{30} \mathrm{~N}_{2}$ & $\mathrm{~B}_{20} \mathrm{C}_{3} \mathrm{H}_{30} \mathrm{~N}_{2}$ & $\mathrm{BC}_{4} \mathrm{KN}_{4}$ \\
\hline $\mathrm{CH}_{3} \mathrm{NH}_{2} \mathrm{BH}_{3}$ & $\mathrm{Ca}\left(\mathrm{NH}_{2} \mathrm{BH}_{3}\right)_{2}$ & $\mathrm{KAl}\left(\mathrm{NH}_{2}\right)_{4}$ & $\mathrm{~K}_{5} \mathrm{C}_{2} \mathrm{HN}_{4}$ & $\mathrm{KCaN}_{3} \mathrm{H}_{6}$ \\
\hline $\mathrm{K}\left(\mathrm{HCN}_{2}\right)$ & $\mathrm{K}_{2} \mathrm{LiAlH}_{6}$ & $\mathrm{KLi}_{3}\left(\mathrm{NH}_{2}\right)_{4}$ & $\mathrm{KLi}_{7} \mathrm{~N}_{8} \mathrm{H}_{16}$ & $\mathrm{~K}_{2} \mathrm{Li}\left(\mathrm{NH}_{2}\right)_{3}$ \\
\hline $\mathrm{K}_{2} \mathrm{Mg}\left(\mathrm{NH}_{2}\right)_{4}$ & $\mathrm{~K}_{2} \mathrm{NaAlH}_{6}$ & $\mathrm{~K}_{2} \mathrm{Na}\left(\mathrm{NH}_{2}\right)_{3}$ & $\mathrm{~K}_{3} \mathrm{Si}_{6} \mathrm{~N}_{11} \mathrm{H}_{6}$ & $\mathrm{LiAlMg}_{10} \mathrm{H}_{24}$ \\
\hline $\mathrm{Li}\left(\mathrm{B}(\mathrm{CN})_{4}\right)$ & $\mathrm{Li}_{2} \mathrm{Ca}(\mathrm{NH})_{2}$ & $\mathrm{LiK}\left(\mathrm{BH}_{4}\right)_{2}$ & $\mathrm{Li}\left(\mathrm{NH}_{2} \mathrm{BH}_{3}\right)$ & $\left(\mathrm{Li}\left(\mathrm{NH}_{3}\right)_{4}\right)_{2}\left(\mathrm{~B}_{6} \mathrm{H}_{6}\right)\left(\mathrm{NH}_{3}\right)_{2}$ \\
\hline $\mathrm{LiNa}_{2} \mathrm{AlH}_{6}$ & $\mathrm{LiNa}_{2}\left(\mathrm{NH}_{2}\right)_{3}$ & $\mathrm{LiSc}\left(\mathrm{BH}_{4}\right)_{4}$ & $\mathrm{Mg}\left(\mathrm{BH}_{4}\right)_{2}\left(\mathrm{NH}_{3}\right)_{2}$ & $\left(\mathrm{NH}_{4}\right) \mathrm{B}(\mathrm{CN})_{4}$ \\
\hline $\mathrm{NaAl}\left(\mathrm{NH}_{2}\right)_{4}$ & $\mathrm{NaB}(\mathrm{CN})_{4}$ & $\mathrm{Si}_{2} \mathrm{C}_{7} \mathrm{H}_{18} \mathrm{~N}_{2}$ & $\mathrm{VC}_{8} \mathrm{H}_{24} \mathrm{~N}_{4}$ & \\
\hline \multicolumn{5}{|c|}{ Five-element compounds } \\
\hline $\mathrm{LiAlC}_{4} \mathrm{H}_{16} \mathrm{~N}_{4}$ & $\mathrm{LiSi}_{3} \mathrm{C}_{9} \mathrm{H}_{27} \mathrm{~N}_{2}$ & $\mathrm{Si}_{2} \mathrm{~B}_{2} \mathrm{C}_{12} \mathrm{H}_{37} \mathrm{~N}_{5}$ & & \\
\hline
\end{tabular}

\section{Results}

Our thermodynamic calculations identified 74 promising single-step reactions that are predicted to have $15 \mathrm{~kJ} / \mathrm{mol} \mathrm{H}_{2} \leq \Delta \mathrm{U}_{0} \leq 75 \mathrm{~kJ} / \mathrm{mol} \mathrm{H}_{2}$ and that release $\geq 6.0 \mathrm{wt} . \% \mathrm{H}_{2}$. These 74 reactions are shown in Table 2. An initial way to consider this set of reactions is to compare them to the 43 single-step reactions that were identified in the earlier calculations by Alapati et al. ${ }^{23}$ Only 17 of these 43 reactions appear among the 74 reactions listed in Table 2; 26 of the reaction mixtures identified by Alapati et al. are predicted by our more complete database to not satisfy the screening criteria listed above. Almost all of these 26 reactions involve either $\mathrm{LiBH}_{4}$ or $\mathrm{Mg}\left(\mathrm{BH}_{4}\right)_{2}$, which are now predicted to react via $\mathrm{B}_{12} \mathrm{H}_{12}$-containing intermediates that were unknown at the time of Alapati et al.'s work. The importance of these intermediates has been discussed in a number of recent reports. ${ }^{22,25,26,28} 57$ of the reactions identified by our calculations were not encountered in the calculations of Alapati et al. because they include one or more compounds that were not included in the database used in those calculations. 
The 74 reactions listed in Table 2 were found by calculations that consider systems that are able to reach perfect thermodynamic equilibrium in an environment where $\mathrm{H}_{2}$ is the only possible gas species. To discuss these reactions, it is useful to divide them into several classes that are arranged by our expectations for how reasonable these assumptions are. We first consider reactions that involve species that include $\mathrm{B}_{12} \mathrm{H}_{12} ; 13$ reactions include species of this type. These reactions do not include any refractory materials or carbon. The reaction mixtures found in our calculations are consistent with those already reported by Ozolins et al. for $\mathrm{LiBH}_{4}$, $\mathrm{Ca}\left(\mathrm{BH}_{4}\right)_{2}, \mathrm{Mg}\left(\mathrm{BH}_{4}\right)_{2}, \mathrm{MgH}_{2} / \mathrm{MgB}_{12} \mathrm{H}_{12}, \mathrm{LiBH}_{4} / \mathrm{Mg}\left(\mathrm{BH}_{4}\right)_{2}$, and $\mathrm{Mg}\left(\mathrm{BH}_{4}\right)_{2} / \mathrm{Ca}\left(\mathrm{BH}_{4}\right)_{2}{ }^{22}$ and $\mathrm{Kim}$ et al. for $\mathrm{LiSc}\left(\mathrm{BH}_{4}\right)_{4}{ }^{27}$ There are also several experimental reports related to the mixtures of $\mathrm{LiBH}_{4}, \mathrm{Ca}\left(\mathrm{BH}_{4}\right)_{2}, \mathrm{Mg}\left(\mathrm{BH}_{4}\right)_{2}, \mathrm{MgH}_{2} / \mathrm{MgB}_{12} \mathrm{H}_{12}$, and $\mathrm{LiBH}_{4} / \mathrm{Mg}\left(\mathrm{BH}_{4}\right)_{2}$. ${ }^{6,25,26,28,38-45}$ Unfortunately, most experimental studies indicate metal closoboranes are very kinetically stable, meaning that reactions involving any $\mathrm{B}_{12} \mathrm{H}_{12}$ species are typically not reversible. ${ }^{22,46}$ This observation suggests that the 13 reactions involving $\mathrm{M}_{n} \mathrm{~B}_{12} \mathrm{H}_{12}(\mathrm{M}=\mathrm{Li}, \mathrm{Mg}, \mathrm{Ca}$, and $\mathrm{K})$ would be undesirable from a practical point of view.

The reactions involving $\mathrm{B}_{12} \mathrm{H}_{12}$ species illustrate one way in which a reaction that is thermodynamically feasible may be strongly limited by kinetic effects. It is reasonable to suspect that similar kinetic limitations could limit the viability of reactions whose reactants or products are known to be refractory. Among the materials we considered, $\mathrm{BN}, \mathrm{TiB}_{2}, \mathrm{ScB}_{2}, \mathrm{AlN}, \mathrm{VN}$, $\mathrm{CaB}_{6}$, and $\mathrm{V}_{2} \mathrm{~N}$ can all be characterized as refractory materials because they have melting temperatures $\geq 2000^{\circ} \mathrm{C}^{47-53}$ Thirty-nine of the reactions listed in Table 2 involve one or more of these species. Ten of the 39 reactions were already predicted by Alapati, Johnson, and Sholl: ${ }^{23}$ $2 \mathrm{LiH}+\mathrm{LiNH}_{2}+\mathrm{BN}, 2 \mathrm{LiBH}_{4}+\mathrm{ScH}_{2}, 2 \mathrm{LiBH}_{4}+\mathrm{TiH}_{2}, 2 \mathrm{LiBH} 4+\mathrm{Mg}\left(\mathrm{NH}_{2}\right)_{2}, \mathrm{ScH}_{2}+\mathrm{Mg}\left(\mathrm{BH}_{4}\right)_{2}$, $3 \mathrm{LiBH}_{4}+\mathrm{TiN}, 12 \mathrm{LiH}+3 \mathrm{Mg}\left(\mathrm{NH}_{2}\right)_{2}+4 \mathrm{BN}, 2 \mathrm{ScN}+3 \mathrm{Mg}\left(\mathrm{BH}_{4}\right)_{2}, 2 \mathrm{TiN}+3 \mathrm{Mg}\left(\mathrm{BH}_{4}\right)_{2}$ and, $4 \mathrm{LiH}+3 \mathrm{LiNH}_{2}+\mathrm{VN}$. There are also relevant theoretical reports showing the same reaction schemes as our current prediction for $\mathrm{CaH}_{2} / \mathrm{CaB}_{12} \mathrm{H}_{12}, \mathrm{ScH}_{2} / \mathrm{Ca}\left(\mathrm{BH}_{4}\right)_{2}$, and $\mathrm{TiH}_{2} / \mathrm{Ca}\left(\mathrm{BH}_{4}\right)_{2} \cdot{ }^{22,24,54}$ A few experimental reports support the idea that refractory materials make reactions involving them irreversible. ${ }^{55,56}$ Purewal et al. experimentally examined hydrogen absorption and desorption behavior in the $\mathrm{LiBH}_{4} / \mathrm{ScH}_{2}$ system. ${ }^{55}$ They did not observe any reaction between $\mathrm{LiBH}_{4}$ and $\mathrm{ScH}_{2}$, presumably due to the stability of $\mathrm{ScH}_{2}$ and $\mathrm{ScB}_{2}$. Yang et al. experimentally studied $\mathrm{LiBH}_{4} / \mathrm{TiH}_{2}$, another reaction system included in this category. ${ }^{56}$ Similar to Purewal et al., they observed that $\mathrm{LiBH}_{4}$ decomposed to release $\mathrm{H}_{2}$ without reacting with $\mathrm{TiH}_{2}$. They also examined the reversibility of the $\mathrm{LiBH}_{4} / \mathrm{CaH}_{2}$ system and concluded that the system was not reversible due to the kinetic stability of $\mathrm{CaB}_{6}$.

The reactions we have discussed above are likely to be impractical because of kinetic limitations. It is also possible that some of the reactions predicted by our calculations may differ from experimental observations because of the formation of non $-\mathrm{H}_{2}$ gases at equilibrium. This issue was discussed in detail in recent work that reported thermodynamic calculations for a small number of metal hydrides that included a wide range of potential gas species, not just $\mathrm{H}_{2}{ }^{57}$ One class of chemical mixtures highlighted in that work was those that involve $\mathrm{C}$. In these mixtures the thermodynamically stable states at low temperatures often involved high levels of $\mathrm{CH}_{4}$. It 
appears in general to be incorrect to assume that calculations that do not allow for the presence of $\mathrm{CH}_{4}$ can predict the correct thermodynamic equilibrium states when carbon is present in the reaction mixture. For this reason, we have separated the 19 reactions in Table 2 that involve carbon either as graphitic $\mathrm{C}$ or as part of a compound such as $\mathrm{KC}_{8}$.

The discussion of the potential role of methane in reaction mixtures involving $\mathrm{C}$ could lead to the conclusion that it would be better to simply exclude all $\mathrm{C}$-containing materials from the materials considered in our calculations. We feel, however, that it is better to report the results involving these compounds because the kinetic implications of mixing metal hydrides and carbon experimentally are not yet clear. There are recent reports showing that nanoporous carbons can improve reaction kinetics in metal hydride systems. ${ }^{58-62}$ Berseth et al., for example, examined the interaction between carbon nanostructures and $\mathrm{NaAlH}_{4}$ and concluded that the carbon materials could improve the dehydrogenation reaction of $\mathrm{NaAlH}_{4}{ }^{59}$ These experiments indicated that the nanostructured $\mathrm{C}$ did not react with the metal hydride. In interpreting experiments of this kind, however, it is important to be aware of the potential reactions that can occur between metal hydrides and carbon supports.

Table 2: Promising single-step reactions divided into six categories. $\Delta \mathrm{U}_{0}$ and $\Delta \mathrm{S}_{\text {conf }}$ represent the changes of the reaction enthalpy at $0 \mathrm{~K}$ and the configurational entropy. The configurational entropy is only listed systems having partial occupancies. The enthalpy changes at $0 \mathrm{~K}$ for reactions involving $\mathrm{LiBH}_{4}$ used the DFT total energy of ortho-LiBH 4 .

\begin{tabular}{|c|c|c|}
\hline Interesting reactions (3 reactions) & wt. \% & $\begin{array}{l}\Delta U_{0}\left(T \Delta S_{\text {conf }}\right) \\
\left(\mathrm{kJ} / \mathrm{mol} \mathrm{H}_{2}\right)\end{array}$ \\
\hline $\mathrm{MgH}_{2} \rightarrow \mathrm{Mg}+\mathrm{H}_{2}$ & 7.66 & 64.7 \\
\hline $\mathrm{LiH}+2 \mathrm{LiNH}_{2}+\mathrm{KBH}_{4} \rightarrow \mathrm{Li}_{3} \mathrm{BN}_{2}+\mathrm{KH}+4 \mathrm{H}_{2}$ & 7.48 & $43.6(-7.2)$ \\
\hline $2 \mathrm{MgH}_{2}+\mathrm{Mg}\left(\mathrm{NH}_{2}\right)_{2} \rightarrow \mathrm{Mg}_{3} \mathrm{~N}_{2}+4 \mathrm{H}_{2}$ & 7.4 & 26 \\
\hline Reactions involving $\mathrm{B}_{12} \mathrm{H}_{12}$ species (13 reactions) & wt. \% & $\begin{array}{l}\Delta U_{0}\left(T \Delta S_{\text {conf }}\right) \\
\left(\mathrm{kJ} / \mathrm{mol} \mathrm{H}_{2}\right)\end{array}$ \\
\hline $\mathrm{LiBH}_{4} \rightarrow(5 / 6) \mathrm{LiH}+(1 / 12) \mathrm{Li}_{2} \mathrm{~B}_{12} \mathrm{H}_{12}+(13 / 12) \mathrm{H}_{2}$ & 10.03 & 62.1 \\
\hline $4 \mathrm{LiBH}_{4}+5 \mathrm{Si}+10 \mathrm{Mg}\left(\mathrm{BH}_{4}\right)_{2} \rightarrow 5 \mathrm{Mg}_{2} \mathrm{Si}+2 \mathrm{Li}_{2} \mathrm{~B}_{12} \mathrm{H}_{12}+36 \mathrm{H}_{2}$ & 9.46 & 41 \\
\hline $5 \mathrm{Si}+12 \mathrm{Mg}\left(\mathrm{BH}_{4}\right)_{2} \rightarrow 5 \mathrm{Mg}_{2} \mathrm{Si}+2 \mathrm{MgB}_{12} \mathrm{H}_{12}+36 \mathrm{H}_{2}$ & 9.21 & 43.6 \\
\hline $5 \mathrm{Si}+10 \mathrm{Mg}\left(\mathrm{BH}_{4}\right)_{2}+2 \mathrm{Ca}\left(\mathrm{BH}_{4}\right)_{2} \rightarrow 5 \mathrm{Mg}_{2} \mathrm{Si}+2 \mathrm{CaB}_{12} \mathrm{H}_{12}+36 \mathrm{H}_{2}$ & 8.85 & 41.2 \\
\hline $2 \mathrm{LiBH}_{4}+5 \mathrm{Mg}\left(\mathrm{BH}_{4}\right)_{2} \rightarrow 5 \mathrm{MgH}_{2}+\mathrm{Li}_{2} \mathrm{~B}_{12} \mathrm{H}_{12}+13 \mathrm{H}_{2}$ & 8.36 & 43.1 \\
\hline $5 \mathrm{Si}+10 \mathrm{Mg}\left(\mathrm{BH}_{4}\right)_{2}+4 \mathrm{KBH}_{4} \rightarrow 5 \mathrm{Mg}_{2} \mathrm{Si}+2 \mathrm{~K}_{2} \mathrm{~B}_{12} \mathrm{H}_{12}+36 \mathrm{H}_{2}$ & 8.1 & $37.3(-2.9)$ \\
\hline $\mathrm{Mg}\left(\mathrm{BH}_{4}\right)_{2} \rightarrow(5 / 6) \mathrm{MgH}_{2}+(1 / 6) \mathrm{MgB}_{12} \mathrm{H}_{12}+(13 / 6) \mathrm{H}_{2}$ & 8.09 & 47.1 \\
\hline $\mathrm{LiSc}\left(\mathrm{BH}_{4}\right)_{4} \rightarrow(2 / 5) \mathrm{LiBH}_{4}+\mathrm{ScH}_{2}+(3 / 10) \mathrm{Li}_{2} \mathrm{~B}_{12} \mathrm{H}_{12}+(22 / 5) \mathrm{H}_{2}$ & 7.97 & 24.1 \\
\hline $5 \mathrm{Mg}\left(\mathrm{BH}_{4}\right)_{2}+\mathrm{Ca}\left(\mathrm{BH}_{4}\right)_{2} \rightarrow 5 \mathrm{MgH}_{2}+\mathrm{CaB}_{12} \mathrm{H}_{12}+13 \mathrm{H}_{2}$ & 7.72 & 43.1 \\
\hline $5 \mathrm{MgH}_{2}+\mathrm{MgB}_{12} \mathrm{H}_{12} \rightarrow 6 \mathrm{MgB}_{2}+11 \mathrm{H}_{2}$ & 7.45 & 62.1 \\
\hline $5 \mathrm{Mg}\left(\mathrm{BH}_{4}\right)_{2}+2 \mathrm{KBH}_{4} \rightarrow 5 \mathrm{MgH}_{2}+\mathrm{K}_{2} \mathrm{~B}_{12} \mathrm{H}_{12}+13 \mathrm{H}_{2}$ & 6.94 & $38(-4)$ \\
\hline $\mathrm{Ca}\left(\mathrm{BH}_{4}\right)_{2} \rightarrow(5 / 6) \mathrm{CaH}_{2}+(1 / 6) \mathrm{CaB}_{12} \mathrm{H}_{12}+(13 / 6) \mathrm{H}_{2}$ & 6.26 & 57.4 \\
\hline
\end{tabular}




\begin{tabular}{|c|c|c|}
\hline $\mathrm{LiH}+3 \mathrm{Ca}\left(\mathrm{BH}_{4}\right)_{2} \rightarrow 3 \mathrm{CaH}_{2}+(1 / 2) \mathrm{Li}_{2} \mathrm{~B}_{12} \mathrm{H}_{12}+(13 / 2) \mathrm{H}_{2}$ & 6.03 & 56.5 \\
\hline $\begin{array}{l}\text { Reactions involving refractory materials } \\
\left(\mathrm{BN}, \mathrm{TiB}_{2}, \mathrm{ScB}_{2}, \mathrm{AIN}, \mathrm{VN}, \mathrm{CaB}_{6}, \mathrm{~V}_{2} \mathrm{~N}\right) \\
(39 \text { reactions) }\end{array}$ & wt.\% & $\begin{array}{l}\Delta \mathrm{U}_{0}\left(\mathrm{~T} \Delta \mathrm{S}_{\mathrm{conf}}\right) \\
\left(\mathrm{kJ} / \mathbf{m o l ~} \mathrm{H}_{2}\right)\end{array}$ \\
\hline $27 \mathrm{~N}_{2} \mathrm{BH}_{7}+\mathrm{AlNC}_{3} \mathrm{H}_{10} \rightarrow \mathrm{AlN}+27 \mathrm{BN}+(3 / 2) \mathrm{C}_{2} \mathrm{H}_{18} \mathrm{~N}_{18}+86 \mathrm{H}_{2}$ & 13.08 & 65.6 \\
\hline$\left(\mathrm{NH}_{4}\right)_{2} \mathrm{~B}_{12} \mathrm{H}_{12} \rightarrow 10 \mathrm{~B}+2 \mathrm{BN}+10 \mathrm{H}_{2}$ & 11.33 & 44 \\
\hline $\begin{array}{l}5 \mathrm{LiSc}\left(\mathrm{BH}_{4}\right)_{4}+2\left(\mathrm{NH}_{4}\right)_{2} \mathrm{~B}_{12} \mathrm{H}_{12} \rightarrow \\
5 \mathrm{ScB}_{2}+4 \mathrm{BN}+(5 / 2) \mathrm{Li}_{2} \mathrm{~B}_{12} \mathrm{H}_{12}+45 \mathrm{H}_{2}\end{array}$ & 9.95 & 15 \\
\hline $20 \mathrm{SiC}+19\left(\mathrm{NH}_{4}\right)_{2} \mathrm{~B}_{12} \mathrm{H}_{12} \rightarrow 38 \mathrm{BN}+20 \mathrm{SiB}_{3}+10 \mathrm{~B}_{13} \mathrm{C}_{2}+190 \mathrm{H}_{2}$ & 9.16 & 40.8 \\
\hline $2 \mathrm{LiBH}_{4}+\mathrm{ScH}_{2} \rightarrow 2 \mathrm{LiH}+\mathrm{ScB}_{2}+4 \mathrm{H}_{2}$ & 8.91 & 49.7 \\
\hline $2 \mathrm{LiBH}_{4}+\mathrm{TiH}_{2} \rightarrow 2 \mathrm{LiH}+\mathrm{TiB}_{2}+4 \mathrm{H}_{2}$ & 8.63 & 22.2 \\
\hline $\mathrm{ScB}_{2}+\left(\mathrm{NH}_{4}\right)_{2} \mathrm{~B}_{12} \mathrm{H}_{12} \rightarrow \mathrm{ScB}_{12}+2 \mathrm{BN}+10 \mathrm{H}_{2}$ & 8.25 & 41.5 \\
\hline $9 \mathrm{ScH}_{2}+\mathrm{Si}+9 \mathrm{Mg}\left(\mathrm{BH}_{4}\right)_{2} \rightarrow 7 \mathrm{MgH}_{2}+\mathrm{Mg}_{2} \mathrm{Si}+9 \mathrm{ScB}_{2}+38 \mathrm{H}_{2}$ & 8.18 & 37.3 \\
\hline $2 \mathrm{LiBH}_{4}+\mathrm{Mg}\left(\mathrm{NH}_{2}\right)_{2} \rightarrow \mathrm{MgH}_{2}+2 \mathrm{LiH}+2 \mathrm{BN}+4 \mathrm{H}_{2}$ & 8.07 & 20.6 \\
\hline $\mathrm{ScH}_{2}+\mathrm{Mg}\left(\mathrm{BH}_{4}\right)_{2} \rightarrow \mathrm{MgH}_{2}+\mathrm{ScB}_{2}+4 \mathrm{H}_{2}$ & 7.99 & 37.5 \\
\hline $\mathrm{BN}+\mathrm{LiSc}\left(\mathrm{BH}_{4}\right)_{4} \rightarrow(1 / 5) \mathrm{LiBH}_{4}+\mathrm{ScN}+(2 / 5) \mathrm{Li}_{2} \mathrm{~B}_{12} \mathrm{H}_{12}+(26 / 5) \mathrm{H}_{2}$ & 7.7 & 22.8 \\
\hline $3 \mathrm{Mg}\left(\mathrm{NH}_{2}\right)_{2}+4 \mathrm{NaBH}_{4} \rightarrow 4 \mathrm{NaH}+\mathrm{Mg}_{3} \mathrm{~N}_{2}+4 \mathrm{BN}+12 \mathrm{H}_{2}$ & 7.55 & $34.4(-8.8)$ \\
\hline $11 \mathrm{LiH}+25 \mathrm{LiNH}_{2}+\mathrm{AlB}_{12} \rightarrow \mathrm{AlN}+12 \mathrm{Li}_{3} \mathrm{BN}_{2}+(61 / 2) \mathrm{H}_{2}$ & 7.51 & 56 \\
\hline $41 \mathrm{ScH}_{2}+4 \mathrm{VB}_{2}+40 \mathrm{Mg}\left(\mathrm{BH}_{4}\right)_{2} \rightarrow 40 \mathrm{MgH}_{2}+41 \mathrm{ScB}_{2}+2 \mathrm{~V}_{2} \mathrm{~B}_{3}+161 \mathrm{H}_{2}$ & 7.42 & 37.2 \\
\hline $10 \mathrm{Si}+3\left(\mathrm{NH}_{4}\right)_{2} \mathrm{~B}_{12} \mathrm{H}_{12} \rightarrow 6 \mathrm{BN}+10 \mathrm{SiB}_{3}+30 \mathrm{H}_{2}$ & 7.42 & 38.7 \\
\hline $3 \mathrm{LiBH}_{4}+\mathrm{TiN} \rightarrow 3 \mathrm{LiH}+\mathrm{TiB}_{2}+\mathrm{BN}+(9 / 2) \mathrm{H}_{2}$ & 7.13 & 35.9 \\
\hline $\mathrm{NaAl}\left(\mathrm{NH}_{2}\right)_{4} \rightarrow \mathrm{AlN}+\mathrm{NaN}_{3}+4 \mathrm{H}_{2}$ & 7.07 & 16.2 \\
\hline $\mathrm{ScH}_{2}+\mathrm{Ca}\left(\mathrm{BH}_{4}\right)_{2} \rightarrow \mathrm{CaH}_{2}+\mathrm{ScB}_{2}+4 \mathrm{H}_{2}$ & 6.91 & 46.8 \\
\hline $3 \mathrm{LiNH}_{2}+2 \mathrm{KBH}_{4} \rightarrow \mathrm{Li}_{3} \mathrm{BN}_{2}+\mathrm{BN}+2 \mathrm{KH}+6 \mathrm{H}_{2}$ & 6.84 & $41.6(-9.7)$ \\
\hline $56 \mathrm{LiH}+21 \mathrm{Mg}\left(\mathrm{NH}_{2}\right)_{2}+4 \mathrm{~V}_{2} \mathrm{~N} \rightarrow 8 \mathrm{Li}_{7} \mathrm{~N}_{4} \mathrm{~V}+7 \mathrm{Mg}_{3} \mathrm{~N}_{2}+70 \mathrm{H}_{2}$ & 6.75 & 47.9 \\
\hline $\mathrm{TiH}_{2}+\mathrm{Ca}\left(\mathrm{BH}_{4}\right)_{2} \rightarrow \mathrm{CaH}_{2}+\mathrm{TiB}_{2}+4 \mathrm{H}_{2}$ & 6.74 & 19.3 \\
\hline $12 \mathrm{LiH}+3 \mathrm{Mg}\left(\mathrm{NH}_{2}\right)_{2}+4 \mathrm{BN} \rightarrow 4 \mathrm{Li}_{3} \mathrm{BN}_{2}+\mathrm{Mg}_{3} \mathrm{~N}_{2}+12 \mathrm{H}_{2}$ & 6.65 & 54.2 \\
\hline $\mathrm{LiNH}_{2}+\mathrm{NaBH}_{4} \rightarrow \mathrm{LiH}+\mathrm{NaH}+\mathrm{BN}+2 \mathrm{H}_{2}$ & 6.63 & $19.4(-11.3)$ \\
\hline $\begin{array}{l}5 \mathrm{LiSc}\left(\mathrm{BH}_{4}\right)_{4}+2 \mathrm{MgB}_{12} \mathrm{H}_{12} \rightarrow \\
5 \mathrm{ScB}_{2}+2 \mathrm{Mg}\left(\mathrm{BH}_{4}\right)_{2}+(5 / 2) \mathrm{Li}_{2} \mathrm{~B}_{12} \mathrm{H}_{12}+29 \mathrm{H}_{2}\end{array}$ & 6.58 & 21.6 \\
\hline $\mathrm{ScH}_{2}+2 \mathrm{NaBH}_{4} \rightarrow 2 \mathrm{NaH}+\mathrm{ScB}_{2}+4 \mathrm{H}_{2}$ & 6.58 & $67.5(-19.8)$ \\
\hline $39 \mathrm{LiNH}_{2}+2 \mathrm{AlB}_{12} \rightarrow 2 \mathrm{AlN}+13 \mathrm{Li}_{3} \mathrm{BN}_{2}+11 \mathrm{BN}+39 \mathrm{H}_{2}$ & 6.5 & 59.5 \\
\hline $2 \mathrm{ScN}+3 \mathrm{Mg}\left(\mathrm{BH}_{4}\right)_{2} \rightarrow 3 \mathrm{MgH}_{2}+2 \mathrm{ScB}_{2}+2 \mathrm{BN}+9 \mathrm{H}_{2}$ & 6.48 & 43.1 \\
\hline $5 \mathrm{NaBH}_{4}+2\left(\mathrm{NH}_{4}\right)_{2} \mathrm{~B}_{12} \mathrm{H}_{12} \rightarrow 4 \mathrm{BN}+(5 / 2) \mathrm{Na}_{2}\left(\mathrm{~B}_{10} \mathrm{H}_{10}\right)+(35 / 2) \mathrm{H}_{2}$ & 6.47 & $26.7(-6.7)$ \\
\hline $\mathrm{TiH}_{2}+2 \mathrm{NaBH}_{4} \rightarrow 2 \mathrm{NaH}+\mathrm{TiB}_{2}+4 \mathrm{H}_{2}$ & 6.42 & $40(-15.1)$ \\
\hline $\mathrm{Mg}\left(\mathrm{NH}_{2}\right)_{2}+\mathrm{Ca}\left(\mathrm{BH}_{4}\right)_{2} \rightarrow \mathrm{MgH}_{2}+\mathrm{CaH}_{2}+2 \mathrm{BN}+4 \mathrm{H}_{2}$ & 6.39 & 17.7 \\
\hline $2 \mathrm{TiN}+3 \mathrm{Mg}\left(\mathrm{BH}_{4}\right)_{2} \rightarrow 3 \mathrm{MgH}_{2}+2 \mathrm{TiB}_{2}+2 \mathrm{BN}+9 \mathrm{H}_{2}$ & 6.35 & 19.5 \\
\hline $2 \mathrm{LiH}+\mathrm{LiNH}_{2}+\mathrm{BN} \rightarrow \mathrm{Li}_{3} \mathrm{BN}_{2}+2 \mathrm{H}_{2}$ & 6.33 & 49.1 \\
\hline $\mathrm{CaH}_{2}+\mathrm{CaB}_{12} \mathrm{H}_{12} \rightarrow 2 \mathrm{CaB}_{6}+7 \mathrm{H}_{2}$ & 6.3 & 61.8 \\
\hline
\end{tabular}




\begin{tabular}{|c|c|c|}
\hline $3 \mathrm{Mg}\left(\mathrm{NH}_{2}\right)_{2}+4 \mathrm{KBH}_{4} \rightarrow \mathrm{Mg}_{3} \mathrm{~N}_{2}+4 \mathrm{BN}+4 \mathrm{KH}+12 \mathrm{H}_{2}$ & 6.29 & $46.9(-10.3)$ \\
\hline $8 \mathrm{ScH}_{2}+2 \mathrm{~V}_{2} \mathrm{~B}_{3}+9 \mathrm{Mg}\left(\mathrm{BH}_{4}\right)_{2} \rightarrow 9 \mathrm{MgH}_{2}+8 \mathrm{ScB}_{2}+4 \mathrm{VB}_{2}+35 \mathrm{H}_{2}$ & 6.24 & 37.1 \\
\hline $13 \mathrm{CaH}_{2}+\mathrm{CaSi}_{2}+14 \mathrm{CaB}_{12} \mathrm{H}_{12} \rightarrow 2 \mathrm{Si}+28 \mathrm{CaB}_{6}+97 \mathrm{H}_{2}$ & 6.13 & 60.6 \\
\hline $4 \mathrm{LiH}+3 \mathrm{LiNH}_{2}+\mathrm{VN} \rightarrow \mathrm{Li}_{7} \mathrm{~N}_{4} \mathrm{~V}+5 \mathrm{H}_{2}$ & 6.09 & 37.4 \\
\hline $\mathrm{ScB}_{2}+4 \mathrm{BN}+3 \mathrm{LiSc}\left(\mathrm{BH}_{4}\right)_{4} \rightarrow 4 \mathrm{ScN}+(3 / 2) \mathrm{Li}_{2} \mathrm{~B}_{12} \mathrm{H}_{12}+15 \mathrm{H}_{2}$ & 6.05 & 21.9 \\
\hline $\mathrm{MgH}_{2}+3 \mathrm{BN}+2 \mathrm{MgB}_{12} \mathrm{H}_{12} \rightarrow 3 \mathrm{MgB}_{9} \mathrm{~N}+13 \mathrm{H}_{2}$ & 6.05 & 58.6 \\
\hline Reactions involving C (19 reactions) & wt.\% & $\begin{array}{l}\Delta U_{0}\left(T \Delta S_{\text {conf }}\right) \\
\left(\mathrm{kJ} / \mathbf{m o l ~ H}_{2}\right) \\
\end{array}$ \\
\hline $\mathrm{LiBH}_{4}+\mathrm{C} \rightarrow \mathrm{LiBC}+2 \mathrm{H}_{2}$ & 11.93 & 45.1 \\
\hline $2 \mathrm{C}+\mathrm{Mg}\left(\mathrm{BH}_{4}\right)_{2} \rightarrow \mathrm{MgB}_{2} \mathrm{C}_{2}+4 \mathrm{H}_{2}$ & 10.34 & 43.1 \\
\hline $20 \mathrm{C}+13\left(\mathrm{NH}_{4}\right)_{2} \mathrm{~B}_{12} \mathrm{H}_{12} \rightarrow 26 \mathrm{BN}+10 \mathrm{~B}_{13} \mathrm{C}_{2}+130 \mathrm{H}_{2}$ & 10.27 & 35.2 \\
\hline $2 \mathrm{C}+\mathrm{Ca}\left(\mathrm{BH}_{4}\right)_{2} \rightarrow \mathrm{CaB}_{2} \mathrm{C}_{2}+4 \mathrm{H}_{2}$ & 8.6 & 56.8 \\
\hline $\mathrm{VC}_{8} \mathrm{H}_{24} \mathrm{~N}_{4} \rightarrow 7 \mathrm{C}+\mathrm{VN}+\mathrm{NH}_{4} \mathrm{HCN}_{2}+(19 / 2) \mathrm{H}_{2}$ & 8.42 & 22.8 \\
\hline $\begin{array}{l}214 \mathrm{C}+607 \mathrm{Mg}\left(\mathrm{BH}_{4}\right)_{2}+100 \mathrm{Ca}\left(\mathrm{BH}_{4}\right)_{2} \rightarrow \\
500 \mathrm{MgH}_{2}+107 \mathrm{MgB}_{2} \mathrm{C}_{2}+100 \mathrm{CaB}_{12} \mathrm{H}_{12}+1728 \mathrm{H}_{2}\end{array}$ & 8.23 & 42.4 \\
\hline $\mathrm{C}+\mathrm{KBH}_{4}+\mathrm{K}\left(\mathrm{NH}_{2}\right)\left(\mathrm{NH}_{3}\right)_{2} \rightarrow \mathrm{BN}+\mathrm{K}_{2} \mathrm{CN}_{2}+6 \mathrm{H}_{2}$ & 7.8 & $26.8(-3.8)$ \\
\hline $2 \mathrm{LiH}+2 \mathrm{C}+\mathrm{Ca}\left(\mathrm{BH}_{4}\right)_{2} \rightarrow \mathrm{CaH}_{2}+2 \mathrm{LiBC}+4 \mathrm{H}_{2}$ & 7.35 & 42.2 \\
\hline $4 \mathrm{LiH}+3 \mathrm{Mg}\left(\mathrm{NH}_{2}\right)_{2}+2 \mathrm{C} \rightarrow 2 \mathrm{Li}_{2} \mathrm{CN}_{2}+\mathrm{Mg}_{3} \mathrm{~N}_{2}+8 \mathrm{H}_{2}$ & 7.17 & 47.8 \\
\hline $2 \mathrm{C}+\mathrm{K}\left(\mathrm{NH}_{2}\right)\left(\mathrm{NH}_{3}\right)_{2} \rightarrow(1 / 3) \mathrm{K}_{3} \mathrm{C}_{6} \mathrm{~N}_{9}+4 \mathrm{H}_{2}$ & 7.12 & 68.4 \\
\hline $\mathrm{LiH}+\mathrm{C}+\mathrm{NaBH}_{4} \rightarrow \mathrm{NaH}+\mathrm{LiBC}+2 \mathrm{H}_{2}$ & 6.98 & $62.9(-19)$ \\
\hline $2 \mathrm{LiNH}_{2}+\mathrm{C} \rightarrow \mathrm{Li}_{2} \mathrm{CN}_{2}+2 \mathrm{H}_{2}$ & 6.96 & 31.4 \\
\hline $\begin{array}{l}266 \mathrm{C}+100 \mathrm{KBH}_{4}+383 \mathrm{Ca}\left(\mathrm{BH}_{4}\right)_{2} \rightarrow \\
250 \mathrm{CaH}_{2}+133 \mathrm{CaB}_{2} \mathrm{C}_{2}+50 \mathrm{~K}_{2} \mathrm{~B}_{12} \mathrm{H}_{12}+1182 \mathrm{H}_{2}\end{array}$ & 6.75 & $53.4(-2.6)$ \\
\hline $\mathrm{MgH}_{2}+2 \mathrm{C}+\mathrm{Ca}\left(\mathrm{BH}_{4}\right)_{2} \rightarrow \mathrm{CaH}_{2}+\mathrm{MgB}_{2} \mathrm{C}_{2}+4 \mathrm{H}_{2}$ & 6.71 & 52.4 \\
\hline $\begin{array}{l}14 \mathrm{Li}_{3} \mathrm{Na}\left(\mathrm{NH}_{2}\right)_{4}+5 \mathrm{Na}_{2} \mathrm{CN}_{2}+16 \mathrm{NH}_{4} \mathrm{HCN}_{2} \rightarrow \\
21 \mathrm{Li}_{2} \mathrm{CN}_{2}+24 \mathrm{NaN}_{3}+96 \mathrm{H}_{2}\end{array}$ & 6.71 & 64.6 \\
\hline $2 \mathrm{C}+\mathrm{MgB}_{12} \mathrm{H}_{12} \rightarrow \mathrm{MgB}_{12} \mathrm{C}_{2}+6 \mathrm{H}_{2}$ & 6.36 & 64.3 \\
\hline $16 \mathrm{LiNH}_{2}+\mathrm{KC}_{8} \rightarrow 8 \mathrm{Li}_{2} \mathrm{CN}_{2}+\mathrm{KH}+(31 / 2) \mathrm{H}_{2}$ & 6.22 & 31.7 \\
\hline $7 \mathrm{NaNH}_{2}+2 \mathrm{NH}_{4} \mathrm{HCN}_{2} \rightarrow 2 \mathrm{Na}_{2} \mathrm{CN}_{2}+3 \mathrm{NaN}_{3}+12 \mathrm{H}_{2}$ & 6.18 & 62.8 \\
\hline $\mathrm{Li}_{3} \mathrm{Na}\left(\mathrm{NH}_{2}\right)_{4}+2 \mathrm{C} \rightarrow(3 / 2) \mathrm{Li}_{2} \mathrm{CN}_{2}+(1 / 2) \mathrm{Na}_{2} \mathrm{CN}_{2}+4 \mathrm{H}_{2}$ & 6.11 & 32.6 \\
\hline
\end{tabular}

The discussion above described how 71 of the 74 single step reactions identified by our thermodynamic calculations are unlikely to be of practical interest for reversible $\mathrm{H}_{2}$ storage. Of the remaining 3 reactions that meet our screening criteria, one is the direct decomposition of $\mathrm{MgH}_{2}$. It is well known that the reaction enthalpy of this reaction is too high to allow $\mathrm{H}_{2}$ release at the temperatures desirable in a mobile storage device. ${ }^{13,63-65}$ The observation that the DFTpredicted reaction enthalpy lies towards the upper bound of the range of reaction enthalpies we used in our screening is consistent with this fact. This leaves two single-step reactions that do not 
suffer from any of the possible disadvantages listed above, one with a 2:1:1 mixture of $\mathrm{LiNH}_{2}$, $\mathrm{LiH}$, and $\mathrm{KBH}_{4}$, and the other with a 2:1 mixture of $\mathrm{MgH}_{2}$ and $\mathrm{Mg}\left(\mathrm{NH}_{2}\right)_{2}$. Both of these reactions release $\sim 7.4 \mathrm{wt} . \% \mathrm{H}_{2}$ at completion.

The reaction between $\mathrm{MgH}_{2}$ and $\mathrm{Mg}\left(\mathrm{NH}_{2}\right)_{2}$ forming $\mathrm{Mg}_{3} \mathrm{~N}_{2}$ with $\mathrm{H}_{2}$ release has been analyzed in several previous computational studies. ${ }^{19,23,66}$ Akbarzadeh, Ozolins, and Wolverton computed the free energy for this reaction using DFT. ${ }^{19}$ We performed similar calculations after computing the VDOS for each solid compound in the reaction, and our results are entirely consistent with those of Akbarzadeh, Ozolins, and Wolverton. A van't Hoff plot based on our DFT-calculated free energies is shown in Fig. 1. The predicted reaction temperature for the $\mathrm{MgH}_{2} / \mathrm{Mg}\left(\mathrm{NH}_{2}\right)_{2}$ mixture at a $\mathrm{H}_{2}$ pressure of 1 bar is $160 \mathrm{~K}$, in good agreement with the value $(130 \mathrm{~K})$ reported by Akbarzadeh, Ozolins, and Wolverton. ${ }^{19}$ An important feature of Fig. 1 is that is indicates the (large) range of $\mathrm{H}_{2}$ pressures that are associated with an uncertainty of \pm 10 $\mathrm{kJ} / \mathrm{mol} \mathrm{H}_{2}$. This is the typical uncertainty that is associated with DFT-calculated reaction free energies for metal hydride decomposition reactions where comparisons with detailed experimental data have been possible. ${ }^{4,13,17}$

The 2:1 mixture of $\mathrm{MgH}_{2}$ and $\mathrm{Mg}\left(\mathrm{NH}_{2}\right)_{2}$ was studied in ball milling experiments by $\mathrm{Hu}$ et al. ${ }^{66}$ As predicted by computational studies, they observed that $\mathrm{Mg}_{3} \mathrm{~N}_{2}$ was produced with the release of a stoichiometric amount of $\mathrm{H}_{2}\left(7.4\right.$ wt.\%). Very low levels of $\mathrm{NH}_{3}(\sim 1 \mathrm{ppm})$ were detected. Hu et al. described the thermodynamics of this process using tabulated thermodynamic data, and estimated that the heat of reaction at $298 \mathrm{~K}$ was $3.5 \mathrm{~kJ} / \mathrm{mol} \mathrm{H}_{2}$. This is in reasonable agreement with our DFT-calculated result $\left(\Delta H_{298 \mathrm{~K}}=15.6 \mathrm{~kJ} / \mathrm{mol} \mathrm{H}_{2}\right)$. No experimental information appears to be available regarding the reversibility of this reaction. Figure 1 indicates that large $\mathrm{H}_{2}$ pressures would be necessary to reverse the reaction at room temperature or above. 


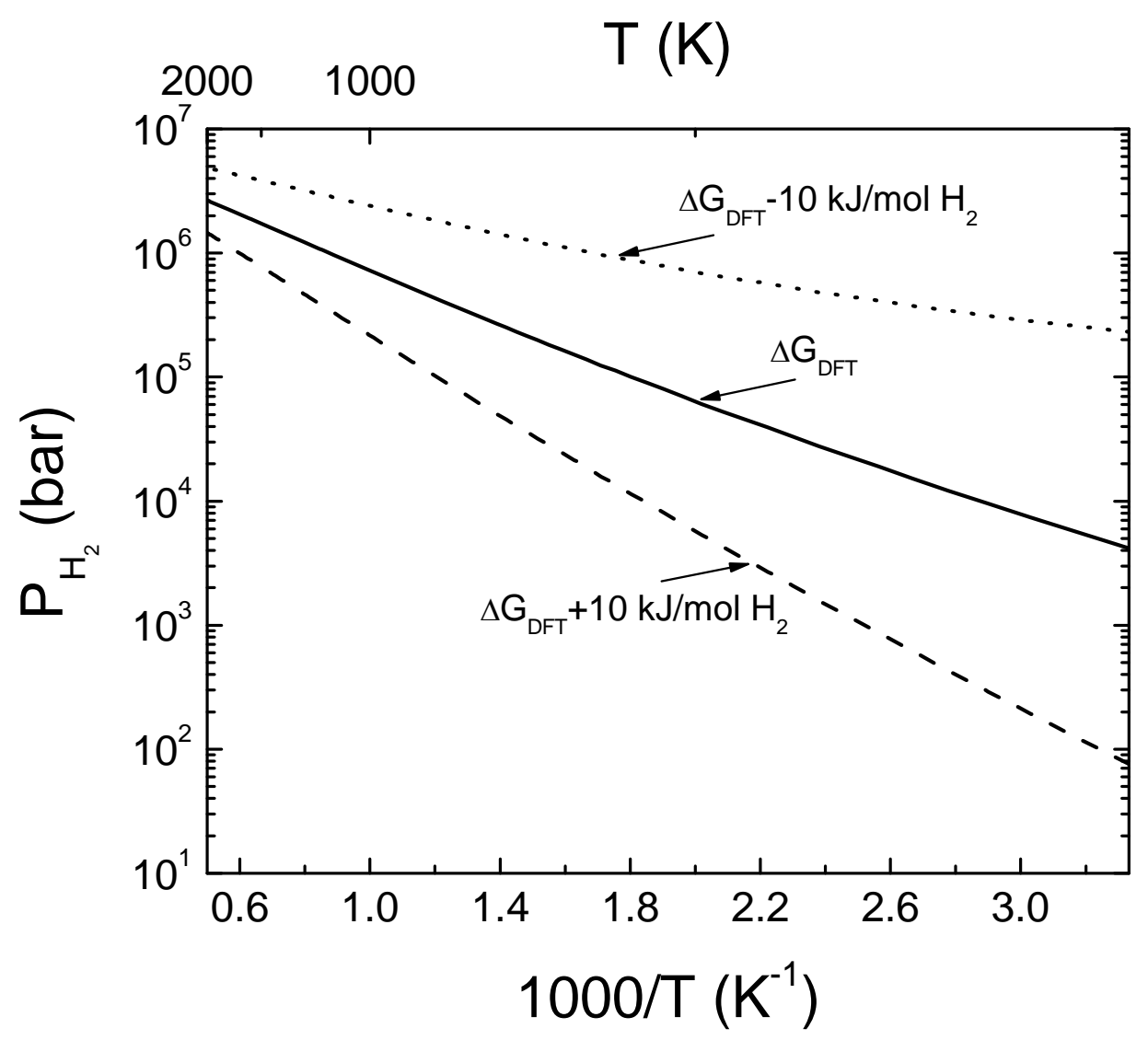

Figure 1: A van't Hoff plot for $2 \mathrm{MgH}_{2}+\mathrm{Mg}\left(\mathrm{NH}_{2}\right)_{2} \rightarrow \mathrm{Mg}_{3} \mathrm{~N}_{2}+4 \mathrm{H}_{2}$. The dotted (dashed) line represents the upper (lower) bound of the van't Hoff plot when an uncertainty of $\pm 10 \mathrm{~kJ} / \mathrm{mol} \mathrm{H}_{2}$ in the DFT-calculated reaction free energy is considered.

The other promising single-step reaction is the reaction of a $2: 1: 1$ mixture of $\mathrm{LiNH}_{2}, \mathrm{LiH}$, and $\mathrm{KBH}_{4}$, which is predicted to react in a single step forming solid $\mathrm{Li}_{3} \mathrm{BN}_{2}$ and $\mathrm{KH}$ along with gaseous $\mathrm{H}_{2}$. This reaction has, to the best of our knowledge, not been considered in any earlier experimental or computational studies. This calculated $0 \mathrm{~K}$ reaction enthalpy change for this reaction is $43.6 \mathrm{~kJ} / \mathrm{mol} \mathrm{H}_{2}$. We computed the VDOS for each solid compound in this reaction in order to analyze the free energy for the reaction. When we consider the vibrational and entropic contributions, our calculation predicts $\Delta H_{300 \mathrm{~K}}=28.1 \mathrm{~kJ} / \mathrm{mol} \mathrm{H}_{2}$ and $\Delta S_{v i b, 300 \mathrm{~K}}$ (the reaction vibrational entropy change at $500 \mathrm{~K})=116.3 \mathrm{~J} / \mathrm{K} / \mathrm{mol} \mathrm{H}_{2}$, giving $\Delta G_{300 \mathrm{~K}}=-6.8 \mathrm{~kJ} / \mathrm{mol} \mathrm{H}_{2}$. As discussed above, the partial disorder of $\mathrm{H}$ atoms in $\alpha-\mathrm{KBH}_{4}$ means that the configurational entropy $\left(S_{\text {conf }}\right)$ associated with this disorder should be considered to completely describe the reaction thermodynamics. If we use an estimate for the configurational entropy based on complete disorder among the partially occupied sites, ${ }^{29}{ }^{9} S_{\text {conf }}$ at $300 \mathrm{~K} \mathrm{is}-3.5 \mathrm{~kJ} / \mathrm{mol} \mathrm{H}_{2}$. As 
discussed in our earlier work on $\mathrm{KBH}_{4}$, this approach is likely to overestimate the entropy associated with site disorder in $\mathrm{KBH}_{4}{ }^{29}$ Therefore, the resulting reaction free energy change including the configurational entropy effect would be $-3.3 \mathrm{~kJ} / \mathrm{mol} \mathrm{H}_{2}$. The van't Hoff plot based on these calculations is shown in Fig. 2. This figure shows that this reaction has the reaction temperatures of $300 \sim 420 \mathrm{~K}$ at $\mathrm{H}_{2}$ pressures of $1 \sim 100 \mathrm{bar}$, indicating that $\mathrm{H}_{2}$ would be released at the appropriate temperatures and $\mathrm{H}_{2}$ pressures for reversible hydrogen storage applications. As with Fig. 1, we show uncertainty estimates in Fig. 2 that emphasize how the imprecision associated with DFT calculations leads to a rather large uncertainty in predicted $\mathrm{H}_{2}$ pressures. Despite this unavoidable uncertainty, the thermodynamic properties of this reaction suggest that it is a good candidate for experimental studies.

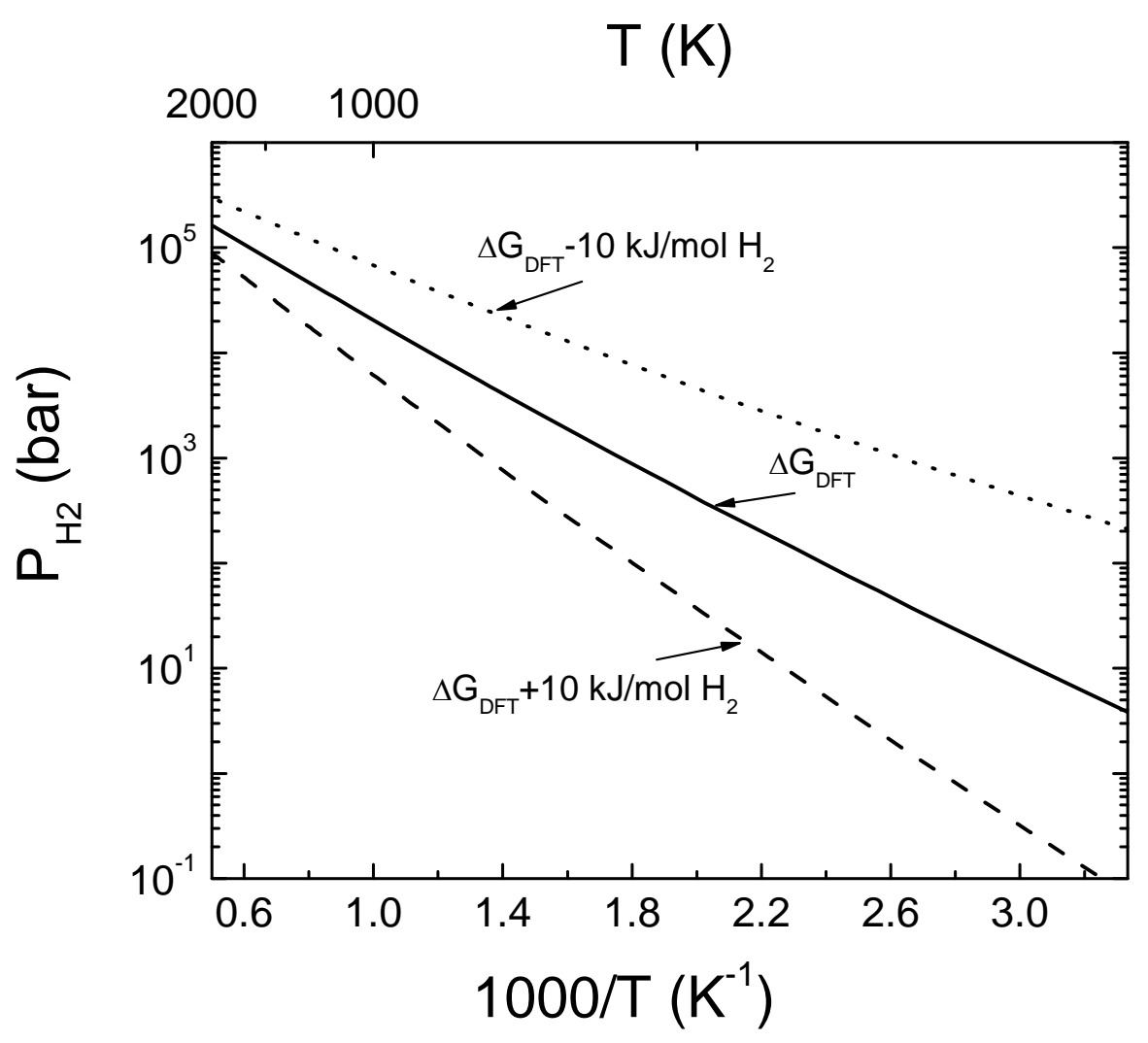

Figure 2: Similar to Fig. 1, but for $2 \mathrm{LiNH}_{2}+\mathrm{LiH}+\mathrm{KBH}_{4} \rightarrow \mathrm{Li}_{3} \mathrm{BN}_{2}+\mathrm{KH}+4 \mathrm{H}_{2}$. 


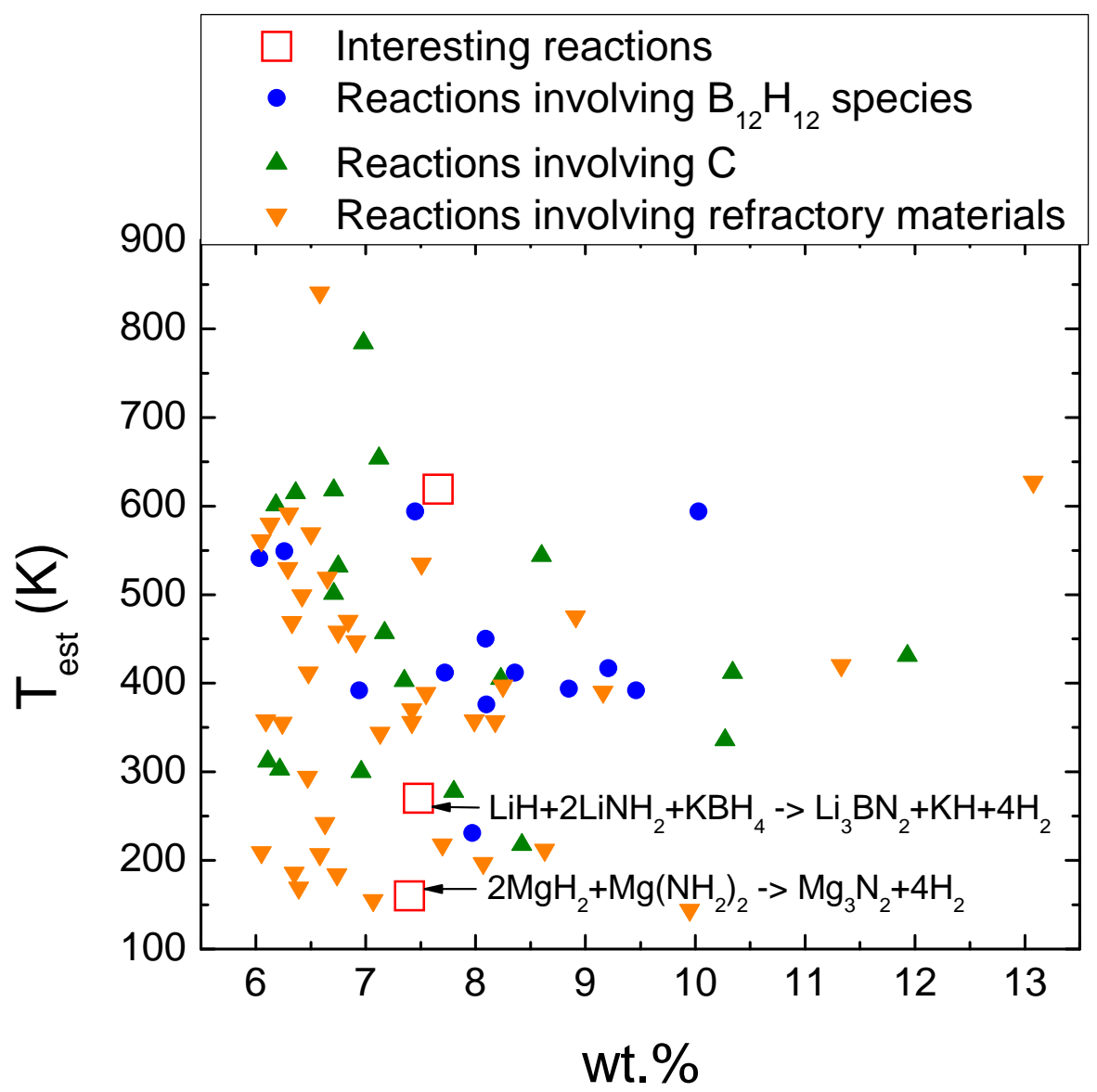

Figure 3: The estimated temperature required to generate a partial pressure of $\mathrm{H}_{2}$ of 1 bar $\left(\mathrm{T}_{\text {est }}\right)$ as a function of $\mathrm{H}_{2}$ capacity (wt.\%) for the 74 promising single-step reactions described in Table 2.

We summarize the main results from visually in Fig. 3 by plotting the estimated reaction temperature for a $\mathrm{H}_{2}$ pressure of 1 bar as a function of the $\mathrm{H}_{2}$ capacity of each single step reaction. For all of the reactions except the two shown in Figs. 1 and 2, the reaction temperature, $T_{\text {est, }}$ was estimated using

$T_{\text {est }}(\mathrm{K})=\Delta U_{0} /(\Delta S-R)$

$\Delta U_{0}$ and $\Delta S$ are the reaction enthalpy at $0 \mathrm{~K}$ and reaction entropy associated with site disorder when this phenomenon is relevant and $R$ is the gas constant. The equation neglects the contributions of the vibrational energies and $P V$ term to the free energies of solid compounds. ${ }^{17,18,67}$ The reaction temperatures of $\mathrm{MgH}_{2} / \mathrm{Mg}\left(\mathrm{NH}_{2}\right)_{2}$ and $\mathrm{LiNH}_{2} / \mathrm{LiH} / \mathrm{KBH}_{4}$ mixtures for a $\mathrm{H}_{2}$ pressure of 1 bar were taken from the van't Hoff plots in Figs. 1 and 2.

We now turn to the possibility of finding multi-step reactions with useful properties for reversible $\mathrm{H}_{2}$ storage. We examined all of the reaction mixtures defined in section 2 to detect 
multi-step reactions in which every step satisfied $15 \leq \Delta \mathrm{U}_{0} \leq 75 \mathrm{~kJ} / \mathrm{mol} \mathrm{H}_{2}$ and the total $\mathrm{H}_{2}$ release from the combined reaction steps was $>6.0 \mathrm{wt} . \% \mathrm{H}_{2}$. This initially generated more than $10^{5}$ candidate reaction mixtures, but this large number contains a much smaller number of distinct reaction schemes. To illustrate this concept, consider the reaction of a mixture of $x$ moles of $\mathrm{Li}_{3} \mathrm{AlH}_{6}$ and $y$ moles of $\mathrm{MgH}_{2}$. For a range of $x$ and $y$, our thermodynamic calculations show that this mixture reacts in two steps as follows:

$$
\begin{aligned}
& x \mathrm{Li}_{3} \mathrm{AlH}_{6} \rightarrow 3 x \mathrm{LiH}+x \mathrm{Al}+1.5 x \mathrm{H}_{2} \\
& y \mathrm{MgH}_{2}+x \mathrm{Al} \rightarrow(x / 30) \mathrm{Al}_{30} \mathrm{Mg}_{23}+(y-23 x / 30) \mathrm{MgH}_{2}+(23 x / 30) \mathrm{H}_{2}
\end{aligned}
$$

The overall $\mathrm{H}_{2}$ capacity of this pair of reactions varies depending on how much $\mathrm{MgH}_{2}$ remains unreacted in the second step. In all families of reactions like this, we chose the net stoichiometry of the mixture to maximize the $\mathrm{H}_{2}$ capacity. Applying this approach reduces the number of distinct multi-step reactions to $\sim 1000$.

In the two step reaction above, the second reaction uses a product from the first reaction as a reactant. We will refer to this situation as a reaction that is linked by an intermediate compound. Examples also exist where two or more independent reactions can be combined to increase the overall $\mathrm{H}_{2}$ capacity relative to one reaction alone. An example of this concept is that reaction of a 10:1:6:2 mixture of $\mathrm{MgH}_{2}: \mathrm{NaMgH}_{3}: \mathrm{Mg}\left(\mathrm{NH}_{2}\right)_{2}: \mathrm{KMgH}_{3}$. This mixture evolves via three reactions that do not use reactants from lower temperature reactions in the higher temperature reactions. The first step, in which a 10:5 ratio of $\mathrm{MgH}_{2}$ and $\mathrm{Mg}\left(\mathrm{NH}_{2}\right)_{2}$ react, releases $5.14 \mathrm{wt} . \% \mathrm{H}_{2}$ relative to the overall mixture. The two additional steps both release $0.514 \mathrm{wt} . \%$ $\mathrm{H}_{2}$, meaning that the net $\mathrm{H}_{2}$ release from the multi-step process is $>6 \mathrm{wt} . \%$.

The individual reactions that are predicted to take place within multi-step reactions could suffer from practical drawbacks for the same reasons discussed in the preceding section. To reflect these issues, we further filtered the multi-step reactions to exclude any reactions that involve carbon in any form or the refractory materials $\mathrm{BN}, \mathrm{TiB}_{2}, \mathrm{ScB}_{2}, \mathrm{AlN}, \mathrm{VN}, \mathrm{CaB}_{6}, \mathrm{~V}_{2} \mathrm{~N}$, $\mathrm{VB}_{2}$, and $\mathrm{V}_{5} \mathrm{Si}_{3}$. In addition, we excluded multi-step reactions including any step with reaction enthalpy at $0 \mathrm{~K}$ higher than $60 \mathrm{~kJ} / \mathrm{mol} \mathrm{H}_{2}$. This filtering of our results led to 23 distinct multi-step reactions, which are listed in Tables 3 and 4 . Table 3 (4) lists the examples that are (are not) linked by intermediate compounds. In general, $\mathrm{LiBH}_{4}$ undergoes the phase transition from the low temperature orthorhombic phase to the high temperature hexagonal phase at $381 \mathrm{~K},{ }^{68-70}$ so that the orthorhombic phase has lower DFT total energy than the hexagonal phase. It implies that if a reaction involving $\mathrm{LiBH}_{4}$ as a reactant occurs at a temperature higher than $381 \mathrm{~K}$, the $0 \mathrm{~K}$ reaction enthalpy change calculated using the DFT energy of the orthorhombic phase will be overestimated. If a low temperature step in a multi step reaction corresponds to the case just described, the step may have higher $0 \mathrm{~K}$ reaction enthalpy change than a high temperature step in the same multi step reaction. Because all the reaction steps involving $\mathrm{LiBH}_{4}$ listed in these tables correspond to this case, we used the DFT total energy of hexagonal $\mathrm{LiBH}_{4}$ to calculate $0 \mathrm{~K}$ reaction enthalpy changes.

Table 3: Multi-step reactions with one or more single step reactions linked via 
intermediate compounds. $\Delta \mathrm{G}_{\max }-\Delta \mathrm{G}_{\min }$ is the difference between $\Delta \mathrm{U}_{0}-\mathrm{T} \Delta \mathrm{S}_{\text {conf }}$ for the final step and the first step in a multi-step reaction. The enthalpy changes at $0 \mathrm{~K}$ for reactions involving $\mathrm{LiBH}_{4}$ used the DFT total energy of the hexagonal phase of $\mathrm{LiBH}_{4}$. The $\mathrm{T} \Delta \mathrm{S}_{\text {conf }}$ term is given only for compounds known to have partial occupancy.

\section{Class I}

(reactions having $\left(\Delta G_{\max }-\Delta G_{\min }\right) \leq 30 \mathrm{~kJ} / \mathrm{mol} \mathrm{H}_{2}$ and not involving $\mathrm{B}_{12} \mathrm{H}_{12}$ species)

\begin{tabular}{|c|c|c|c|c|}
\hline No. & Reaction & wt.\% & $\begin{array}{l}\Delta \mathrm{U}_{0}\left(\mathrm{~T} \Delta \mathrm{S}_{\mathrm{conf}}\right) \\
\left(\mathrm{kJ} / \mathrm{mol} \mathrm{H}_{2}\right)\end{array}$ & $\begin{array}{l}\Delta \mathbf{G}_{\max }-\Delta \mathbf{G}_{\min } \\
\left(\mathrm{kJ} / \mathrm{mol}_{\mathbf{m}} \mathbf{H}_{2}\right)\end{array}$ \\
\hline \multirow{4}{*}{1} & $\begin{array}{l}\text { Entire reaction } \\
36 \mathrm{MgH}_{2}+19 \mathrm{Mg}\left(\mathrm{NH}_{2}\right)_{2}+2 \mathrm{KMgH}_{3} \rightarrow \\
19 \mathrm{Mg}_{3} \mathrm{~N}_{2}+2 \mathrm{KH}+76 \mathrm{H}_{2}\end{array}$ & 7.12 & & \multirow{4}{*}{21.2} \\
\hline & $\begin{array}{l}1^{\text {st }} \text { step } \\
36 \mathrm{MgH}_{2}+18 \mathrm{Mg}\left(\mathrm{NH}_{2}\right)_{2} \rightarrow 18 \mathrm{Mg}_{3} \mathrm{~N}_{2}+72 \mathrm{H}_{2}\end{array}$ & 6.748 & 26 & \\
\hline & $\begin{array}{l}2^{\text {nd }} \text { step } \\
0.5 \mathrm{Mg}\left(\mathrm{NH}_{2}\right)_{2}+2 \mathrm{KMgH}_{3} \rightarrow \\
0.5 \mathrm{Mg}_{3} \mathrm{~N}_{2}+\mathrm{K}_{2} \mathrm{MgH}_{4}+2 \mathrm{H}_{2}\end{array}$ & 0.187 & 38.6 & \\
\hline & $\begin{array}{l}3^{\text {rd }} \text { step } \\
0.5 \mathrm{Mg}\left(\mathrm{NH}_{2}\right)_{2}+\mathrm{K}_{2} \mathrm{MgH}_{4} \rightarrow \\
0.5 \mathrm{Mg}_{3} \mathrm{~N}_{2}+2 \mathrm{KH}+2 \mathrm{H}_{2}\end{array}$ & 0.187 & 47.2 & \\
\hline \multirow{5}{*}{2} & $\begin{array}{l}\text { Entire reaction } \\
13 \mathrm{MgH}_{2}+\mathrm{NaMgH}_{3}+9 \mathrm{Mg}\left(\mathrm{NH}_{2}\right)_{2}+4 \mathrm{KMgH}_{3} \rightarrow \\
\mathrm{NaH}+9 \mathrm{Mg}_{3} \mathrm{~N}_{2}+4 \mathrm{KH}+36 \mathrm{H}_{2}\end{array}$ & 6.23 & & \multirow{5}{*}{21.2} \\
\hline & $\begin{array}{l}1^{\text {st }} \text { step } \\
13 \mathrm{MgH}_{2}+6.5 \mathrm{Mg}\left(\mathrm{NH}_{2}\right)_{2} \rightarrow 6.5 \mathrm{Mg}_{3} \mathrm{~N}_{2}+26 \mathrm{H}_{2}\end{array}$ & 4.498 & 26 & \\
\hline & $\begin{array}{l}2^{\text {nd }} \text { step } \\
\mathrm{NaMgH}_{3}+0.5 \mathrm{Mg}\left(\mathrm{NH}_{2}\right)_{2} \rightarrow \\
\mathrm{NaH}+0.5 \mathrm{Mg}_{3} \mathrm{~N}_{2}+2 \mathrm{H}_{2}\end{array}$ & 0.346 & 31.3 & \\
\hline & $\begin{array}{l}3^{\text {rd }} \text { step } \\
\mathrm{Mg}\left(\mathrm{NH}_{2}\right)_{2}+4 \mathrm{KMgH}_{3} \rightarrow \\
\mathrm{Mg}_{3} \mathrm{~N}_{2}+2 \mathrm{~K}_{2} \mathrm{MgH}_{4}+4 \mathrm{H}_{2}\end{array}$ & 0.692 & 38.6 & \\
\hline & $\begin{array}{l}4^{\text {th }} \text { step } \\
\mathrm{Mg}\left(\mathrm{NH}_{2}\right)_{2}+2 \mathrm{~K}_{2} \mathrm{MgH}_{4} \rightarrow \mathrm{Mg}_{3} \mathrm{~N}_{2}+4 \mathrm{KH}+4 \mathrm{H}_{2}\end{array}$ & 0.692 & 47.2 & \\
\hline \multirow{3}{*}{3} & $\begin{array}{l}\text { Entire reaction } \\
1.58 \mathrm{Li}_{3} \mathrm{AlH}_{6}+1.2 \mathrm{MgH}_{2} \rightarrow \\
4.75 \mathrm{LiH}+0.02 \mathrm{Al}+0.05 \mathrm{Al}_{30} \mathrm{Mg}_{23}+3.58 \mathrm{H}_{2}\end{array}$ & 6.17 & & \multirow{3}{*}{28.1} \\
\hline & $\begin{array}{l}1^{\text {st }} \text { step } \\
1.58 \mathrm{Li}_{3} \mathrm{AlH}_{6} \rightarrow 4.75 \mathrm{LiH}+1.58 \mathrm{Al}+2.38 \mathrm{H}_{2}\end{array}$ & 4.097 & 28.8 & \\
\hline & $\begin{array}{l}2^{\text {nd }} \text { step } \\
1.2 \mathrm{MgH}_{2}+1.56 \mathrm{Al} \rightarrow 0.05 \mathrm{Al}_{30} \mathrm{Mg}_{23}+1.2 \mathrm{H}_{2}\end{array}$ & 2.07 & 56.9 & \\
\hline
\end{tabular}




\begin{tabular}{|c|c|c|c|c|}
\hline \multicolumn{5}{|c|}{ (reactions having $\left(\Delta G_{\max }-\Delta G_{\min }\right) \geq 30 \mathrm{~kJ} / \mathrm{mol} H_{2}$ and not involving $B_{12} H_{12}$ species) } \\
\hline \multirow{4}{*}{1} & $\begin{array}{l}\text { Entire reaction } \\
5.67 \mathrm{Li}_{3} \mathrm{AlH}_{6}+8 \mathrm{MgH}_{2} \rightarrow \\
17 \mathrm{LiH}+0.47 \mathrm{Al}_{12} \mathrm{Mg}_{17}+16.5 \mathrm{H}_{2}\end{array}$ & 6.45 & & \multirow{4}{*}{30.3} \\
\hline & $\begin{array}{l}1^{\text {st }} \text { step } \\
5.67 \mathrm{Li}_{3} \mathrm{AlH}_{6} \rightarrow 17 \mathrm{LiH}+5.67 \mathrm{Al}+(17 / 2) \mathrm{H}_{2}\end{array}$ & 3.323 & 28.8 & \\
\hline & $\begin{array}{l}2^{\text {nd }} \text { step } \\
4.34 \mathrm{MgH}_{2}+3.67 \mathrm{Al} \rightarrow 0.19 \mathrm{Al}_{30} \mathrm{Mg}_{23}+4.34 \mathrm{H}_{2}\end{array}$ & 1.698 & 56.9 & \\
\hline & $\begin{array}{l}3^{\text {rd }} \text { step } \\
3.66 \mathrm{MgH}_{2}+0.19 \mathrm{Al}_{30} \mathrm{Mg}_{23} \rightarrow \\
0.47 \mathrm{Al}_{12} \mathrm{Mg}_{17}+3.66 \mathrm{H}_{2}\end{array}$ & 1.429 & 59.1 & \\
\hline \multirow{6}{*}{2} & $\begin{array}{l}\text { Entire reaction } \\
9 \mathrm{Li}_{3} \mathrm{AlH}_{6}+\mathrm{Al}+\mathrm{Si}+12 \mathrm{MgH}_{2} \rightarrow \\
27 \mathrm{LiH}+\mathrm{Mg}_{2} \mathrm{Si}+0.22 \mathrm{Al}_{30} \mathrm{Mg}_{23} \\
+0.3 \mathrm{Al}_{12} \mathrm{Mg}_{17}+25.5 \mathrm{H}_{2}\end{array}$ & 6.01 & & \multirow{6}{*}{30.8} \\
\hline & $\begin{array}{l}1^{\text {st }} \text { step } \\
0.33 \mathrm{Li}_{3} \mathrm{AlH}_{6}+0.67 \mathrm{Al}+\mathrm{Si} \rightarrow \mathrm{AlLiSi}+\mathrm{H}_{2}\end{array}$ & 0.236 & 28.3 & \\
\hline & $\begin{array}{l}2^{\text {nd }} \text { step } \\
8.67 \mathrm{Li}_{3} \mathrm{AlH}_{6} \rightarrow 26 \mathrm{LiH}+8.67 \mathrm{Al}+13 \mathrm{H}_{2}\end{array}$ & 3.063 & 28.8 & \\
\hline & $\begin{array}{l}3^{\text {rd }} \text { step } \\
2 \mathrm{MgH}_{2}+\mathrm{AlLiSi} \rightarrow \mathrm{LiH}+\mathrm{Al}+\mathrm{Mg}_{2} \mathrm{Si}+1.5 \mathrm{H}_{2}\end{array}$ & 0.353 & 40.7 & \\
\hline & $\begin{array}{l}4^{\text {th }} \text { step } \\
7.67 \mathrm{MgH}_{2}+10 \mathrm{Al} \rightarrow 0.33 \mathrm{Al}_{30} \mathrm{Mg}_{23}+7.67 \mathrm{H}_{2}\end{array}$ & 1.806 & 56.9 & \\
\hline & $\begin{array}{l}5^{\text {th }} \text { step } \\
2.33 \mathrm{MgH}_{2}+0.12 \mathrm{Al}_{30} \mathrm{Mg}_{23} \rightarrow \\
0.3 \mathrm{Al}_{12} \mathrm{Mg}_{17}+2.33 \mathrm{H}_{2}\end{array}$ & 0.55 & 59.1 & \\
\hline \multirow{5}{*}{3} & $\begin{array}{l}\text { Entire reaction } \\
10 \mathrm{Li}_{3} \mathrm{AlH}_{6}+9 \mathrm{MgH}_{2}+\mathrm{ScH}_{2} \rightarrow \\
30 \mathrm{LiH}+\mathrm{Al}_{3} \mathrm{Sc}+0.05 \mathrm{Al}_{30} \mathrm{Mg}_{23} \\
+0.47 \mathrm{Al}_{12} \mathrm{Mg}_{17}+25 \mathrm{H}_{2}\end{array}$ & 6.13 & & \multirow{5}{*}{31.9} \\
\hline & $\begin{array}{l}1^{\text {st }} \text { step } \\
3 \mathrm{Li}_{3} \mathrm{AlH}_{6}+\mathrm{ScH}_{2} \rightarrow 9 \mathrm{LiH}+\mathrm{Al}_{3} \mathrm{Sc}+5.5 \mathrm{H}_{2}\end{array}$ & 1.348 & 27.2 & \\
\hline & $\begin{array}{l}2^{\text {nd }} \text { step } \\
7 \mathrm{Li}_{3} \mathrm{AlH}_{6} \rightarrow 21 \mathrm{LiH}+7 \mathrm{Al}+10.5 \mathrm{H}_{2}\end{array}$ & 2.574 & 28.8 & \\
\hline & $\begin{array}{l}3^{\text {rd }} \text { step } \\
5.37 \mathrm{MgH}_{2}+7 \mathrm{Al} \rightarrow 0.24 \mathrm{Al}_{30} \mathrm{Mg}_{23}+5.37 \mathrm{H}_{2}\end{array}$ & 1.316 & 56.9 & \\
\hline & $\begin{array}{l}4^{\text {th }} \text { step } \\
3.64 \mathrm{MgH}_{2}+0.19 \mathrm{Al}_{30} \mathrm{Mg}_{23} \rightarrow \\
0.47 \mathrm{Al}_{12} \mathrm{Mg}_{17}+3.64 \mathrm{H}_{2}\end{array}$ & 0.891 & 59.1 & \\
\hline 4 & Entire reaction & 6 & & 42.4 \\
\hline
\end{tabular}




\begin{tabular}{|c|c|c|c|c|}
\hline & $\begin{array}{l}9 \mathrm{Li}_{3} \mathrm{AlH}_{6}+7 \mathrm{MgH}_{2}+\mathrm{VH}_{2} \rightarrow \\
27 \mathrm{LiH}+0.69 \mathrm{Al}_{3} \mathrm{~V}+0.05 \mathrm{Al}_{45} \mathrm{~V}_{7} \\
+0.41 \mathrm{Al}_{12} \mathrm{Mg}_{17}+21.5 \mathrm{H}_{2}\end{array}$ & & & \\
\hline & $\begin{array}{l}1^{\text {st }} \text { step } \\
3 \mathrm{Li}_{3} \mathrm{AlH}_{6}+\mathrm{VH}_{2} \rightarrow 9 \mathrm{LiH}+\mathrm{Al}_{3} \mathrm{~V}+5.5 \mathrm{H}_{2}\end{array}$ & 1.536 & 15.1 & \\
\hline & $\begin{array}{l}2^{\text {nd }} \text { step } \\
3.43 \mathrm{Li}_{3} \mathrm{AlH}_{6}+\mathrm{Al}_{3} \mathrm{~V} \rightarrow 10.29 \mathrm{LiH}+0.15 \mathrm{Al}_{45} \mathrm{~V}_{7} \\
+5.15 \mathrm{H}_{2}\end{array}$ & 1.436 & 27.2 & \\
\hline & $\begin{array}{l}3^{\text {rd }} \text { step } \\
2.57 \mathrm{Li}_{3} \mathrm{AlH}_{6} \rightarrow 7.72 \mathrm{LiH}+2.57 \mathrm{Al}+3.86 \mathrm{H}_{2}\end{array}$ & 1.077 & 28.8 & \\
\hline & $\begin{array}{l}4^{\text {th }} \text { step } \\
1.97 \mathrm{MgH}_{2}+2.57 \mathrm{Al} \rightarrow 0.09 \mathrm{Al}_{30} \mathrm{Mg}_{23}+1.97 \mathrm{H}_{2}\end{array}$ & 0.551 & 56.9 & \\
\hline & $\begin{array}{l}5^{\text {th }} \text { step } \\
5.03 \mathrm{MgH}_{2}+0.09 \mathrm{Al}_{30} \mathrm{Mg}_{23}+0.1 \mathrm{Al}_{45} \mathrm{~V}_{7} \rightarrow \\
0.41 \mathrm{Al}_{12} \mathrm{Mg}_{17}+0.69 \mathrm{Al}_{3} \mathrm{~V}+5.03 \mathrm{H}_{2}\end{array}$ & 1.404 & 57.5 & \\
\hline & $\begin{array}{l}\text { s III } \\
\text { tions involving } \mathrm{B}_{12} \mathrm{H}_{12} \text { species) }\end{array}$ & & & \\
\hline & $\begin{array}{l}\text { Entire reaction } \\
24 \mathrm{LiBH}_{4}+\mathrm{KBH}_{4} \rightarrow 20.84 \mathrm{LiH}+1.59 \mathrm{Li}_{2} \mathrm{~B}_{12} \mathrm{H}_{12} \\
+0.5 \mathrm{~K}_{2} \mathrm{~B}_{12} \mathrm{H}_{12}+27.09 \mathrm{H}_{2}\end{array}$ & 9.47 & & \\
\hline 1 & $\begin{array}{l}1^{\text {st }} \text { step } \\
24 \mathrm{LiBH}_{4} \rightarrow 20 \mathrm{LiH}+2 \mathrm{Li}_{2} \mathrm{~B}_{12} \mathrm{H}_{12}+26 \mathrm{H}_{2}\end{array}$ & 9.088 & 47.2 & 13.9 \\
\hline & $\begin{array}{l}2^{\text {nd }} \text { step } \\
\mathrm{KBH}_{4}+0.42 \mathrm{Li}_{2} \mathrm{~B}_{12} \mathrm{H}_{12} \rightarrow \\
0.84 \mathrm{LiH}+0.5 \mathrm{~K}_{2} \mathrm{~B}_{12} \mathrm{H}_{12}+1.09 \mathrm{H}_{2}\end{array}$ & 0.379 & $31.7(-29.4)$ & \\
\hline & $\begin{array}{l}\text { Entire reaction } \\
178 \mathrm{LiBH}_{4}+10 \mathrm{Ca}\left(\mathrm{BH}_{4}\right)_{2}+42 \mathrm{KBH}_{4}+\mathrm{Li}_{2} \mathrm{~B}_{12} \mathrm{H}_{12} \\
\rightarrow 180 \mathrm{LiH}+10 \mathrm{CaH}_{2}+21 \mathrm{~K}_{2} \mathrm{~B}_{12} \mathrm{H}_{12}+260 \mathrm{H}_{2}\end{array}$ & 7.49 & & \\
\hline 2 & $\begin{array}{l}1^{\text {st }} \text { step } \\
178 \mathrm{LiBH}_{4} \rightarrow 148.35 \mathrm{LiH}+14.85 \mathrm{Li}_{2} \mathrm{~B}_{12} \mathrm{H}_{12} \\
+192.85 \mathrm{H}_{2}\end{array}$ & 5.556 & 47.2 & 130 \\
\hline 2 & $\begin{array}{l}2^{\text {nd }} \text { step } \\
3.35 \mathrm{LiH}+10 \mathrm{Ca}\left(\mathrm{BH}_{4}\right)_{2} \rightarrow \\
10 \mathrm{CaH}_{2}+1.65 \mathrm{Li}_{2} \mathrm{~B}_{12} \mathrm{H}_{12}+21.65 \mathrm{H}_{2}\end{array}$ & 0.624 & 56.5 & 13.9 \\
\hline & $\begin{array}{l}3^{\text {rd }} \text { step } \\
42 \mathrm{KBH}_{4}+17.5 \mathrm{Li}_{2} \mathrm{~B}_{12} \mathrm{H}_{12} \rightarrow \\
35 \mathrm{LiH}+21 \mathrm{~K}_{2} \mathrm{~B}_{12} \mathrm{H}_{12}+45.5 \mathrm{H}_{2}\end{array}$ & 1.311 & $31.7(-29.4)$ & \\
\hline
\end{tabular}

Table 4: Similar to Table 3 but for multi-step reactions in which individual reactions are not linked by intermediate compounds. 


\begin{tabular}{|c|c|c|c|c|}
\hline \multicolumn{5}{|c|}{$\begin{array}{l}\text { Class I } \\
\left.\text { (reactions having }\left(\Delta G_{\max }-\Delta G_{\min }\right) \leq 10 \mathrm{~kJ} / \mathrm{mol} \mathrm{H}_{2}\right)\end{array}$} \\
\hline No. & Reaction & wt.\% & $\begin{array}{l}\Delta \mathbf{U}_{0}\left(\mathrm{~T} \Delta \mathbf{S}_{\mathrm{conf}}\right) \\
\left(\mathrm{kJ} / \mathbf{m o l ~} \mathbf{H}_{2}\right)\end{array}$ & $\begin{array}{l}\Delta \mathbf{G}_{\max }-\Delta \mathbf{G}_{\min } \\
\left(\mathrm{kJ} / \mathrm{mol} \mathrm{H}_{2}\right)\end{array}$ \\
\hline \multirow{3}{*}{1} & $\begin{array}{l}\text { Entire reaction } \\
6 \mathrm{LiBH}_{4}+15 \mathrm{Mg}\left(\mathrm{BH}_{4}\right)_{2}+\mathrm{MgH}_{2}+8 \mathrm{Si} \rightarrow \\
8 \mathrm{Mg}_{2} \mathrm{Si}+3 \mathrm{Li}_{2} \mathrm{~B}_{12} \mathrm{H}_{12}+55 \mathrm{H}_{2}\end{array}$ & 9.31 & & \multirow{3}{*}{1.6} \\
\hline & $\begin{array}{l}1^{\text {st }} \text { step } \\
\mathrm{MgH}_{2}+0.5 \mathrm{Si} \rightarrow 0.5 \mathrm{Mg}_{2} \mathrm{Si}+\mathrm{H}_{2}\end{array}$ & 0.169 & 37.6 & \\
\hline & $\begin{array}{l}2^{\text {nd }} \text { step } \\
6 \mathrm{LiBH}_{4}+15 \mathrm{Mg}\left(\mathrm{BH}_{4}\right)_{2}+7.5 \mathrm{Si} \rightarrow \\
7.5 \mathrm{Mg}_{2} \mathrm{Si}+3 \mathrm{Li}_{2} \mathrm{~B}_{12} \mathrm{H}_{12}+54 \mathrm{H}_{2}\end{array}$ & 9.136 & 39.2 & \\
\hline \multirow{3}{*}{2} & $\begin{array}{l}\text { Entire reaction } \\
18.33 \mathrm{Si}+40 \mathrm{Mg}\left(\mathrm{BH}_{4}\right)_{2}+4 \mathrm{Ca}\left(\mathrm{BH}_{4}\right)_{2} \rightarrow \\
18.33 \mathrm{Mg}_{2} \mathrm{Si}+3.33 \mathrm{MgB}_{12} \mathrm{H}_{12} \\
+4 \mathrm{CaB}_{12} \mathrm{H}_{12}+132 \mathrm{H}_{2}\end{array}$ & 9.01 & & \multirow{3}{*}{2.4} \\
\hline & $\begin{array}{l}1^{\text {st }} \text { step } \\
10 \mathrm{Si}+20 \mathrm{Mg}\left(\mathrm{BH}_{4}\right)_{2}+4 \mathrm{Ca}\left(\mathrm{BH}_{4}\right)_{2} \rightarrow \\
10 \mathrm{Mg}_{2} \mathrm{Si}+4 \mathrm{CaB}_{12} \mathrm{H}_{12}+72 \mathrm{H}_{2}\end{array}$ & 4.914 & 41.2 & \\
\hline & $\begin{array}{l}2^{\text {nd }} \text { step } \\
8.33 \mathrm{Si}+20 \mathrm{Mg}\left(\mathrm{BH}_{4}\right)_{2} \rightarrow \\
8.33 \mathrm{Mg}_{2} \mathrm{Si}+3.33 \mathrm{MgB}_{12} \mathrm{H}_{12}+60 \mathrm{H}_{2}\end{array}$ & 4.095 & 43.6 & \\
\hline \multirow{3}{*}{3} & $\begin{array}{l}\text { Entire reaction } \\
5 \mathrm{MgH}_{2}+10 \mathrm{Si}+15 \mathrm{Mg}\left(\mathrm{BH}_{4}\right)_{2}+6 \mathrm{KBH}_{4} \rightarrow \\
10 \mathrm{Mg}_{2} \mathrm{Si}+3 \mathrm{~K}_{2} \mathrm{~B}_{12} \mathrm{H}_{12}+59 \mathrm{H}_{2}\end{array}$ & 7.69 & & \multirow{3}{*}{2.6} \\
\hline & $\begin{array}{l}1^{\text {st }} \text { step } \\
5 \mathrm{MgH}_{2}+2.5 \mathrm{Si} \rightarrow 2.5 \mathrm{Mg}_{2} \mathrm{Si}+5 \mathrm{H}_{2}\end{array}$ & 0.652 & 37.6 & \\
\hline & $\begin{array}{l}2^{\text {nd }} \text { step } \\
7.5 \mathrm{Si}+15 \mathrm{Mg}\left(\mathrm{BH}_{4}\right)_{2}+6 \mathrm{KBH}_{4} \rightarrow \\
7.5 \mathrm{Mg}_{2} \mathrm{Si}+3 \mathrm{~K}_{2} \mathrm{~B}_{12} \mathrm{H}_{12}+54 \mathrm{H}_{2}\end{array}$ & 7.042 & $37.3(-2.87)$ & \\
\hline \multirow{3}{*}{4} & $\begin{array}{l}\text { Entire reaction } \\
35 \mathrm{Si}+80 \mathrm{Mg}\left(\mathrm{BH}_{4}\right)_{2}+8 \mathrm{KBH}_{4} \rightarrow \\
35 \mathrm{Mg}_{2} \mathrm{Si}+10 \mathrm{MgB}_{12} \mathrm{H}_{12}+4 \mathrm{~K}_{2} \mathrm{~B}_{12} \mathrm{H}_{12}+252 \mathrm{H}_{2}\end{array}$ & 8.86 & & \multirow{3}{*}{3.5} \\
\hline & $\begin{array}{l}1^{\text {st }} \text { step } \\
10 \mathrm{Si}+20 \mathrm{Mg}\left(\mathrm{BH}_{4}\right)_{2}+8 \mathrm{KBH}_{4} \rightarrow \\
10 \mathrm{Mg}_{2} \mathrm{Si}+4 \mathrm{~K}_{2} \mathrm{~B}_{12} \mathrm{H}_{12}+72 \mathrm{H}_{2}\end{array}$ & 2.532 & $37.3(-2.9)$ & \\
\hline & $\begin{array}{l}2^{\text {nd }} \text { step } \\
25 \mathrm{Si}+60 \mathrm{Mg}\left(\mathrm{BH}_{4}\right)_{2} \rightarrow \\
25 \mathrm{Mg}_{2} \mathrm{Si}+10 \mathrm{MgB}_{12} \mathrm{H}_{12}+180 \mathrm{H}_{2}\end{array}$ & 6.329 & 43.6 & \\
\hline 5 & Entire reaction & 9.38 & & 4.5 \\
\hline
\end{tabular}




\begin{tabular}{|c|c|c|c|c|}
\hline & $\begin{array}{l}16 \mathrm{LiBH}_{4}+28.33 \mathrm{Si}+60 \mathrm{Mg}\left(\mathrm{BH}_{4}\right)_{2} \rightarrow \\
28.33 \mathrm{Mg}_{2} \mathrm{Si}+8 \mathrm{Li}_{2} \mathrm{~B}_{12} \mathrm{H}_{12} \\
+3.33 \mathrm{MgB}_{12} \mathrm{H}_{12}+204 \mathrm{H}_{2}\end{array}$ & & & \\
\hline & $\begin{array}{l}1^{\text {st }} \text { step } \\
16 \mathrm{LiBH}_{4}+20 \mathrm{Si}+40 \mathrm{Mg}\left(\mathrm{BH}_{4}\right)_{2} \rightarrow \\
20 \mathrm{Mg}_{2} \mathrm{Si}+8 \mathrm{Li}_{2} \mathrm{~B}_{12} \mathrm{H}_{12}+144 \mathrm{H}_{2}\end{array}$ & 6.622 & 39.2 & \\
\hline & $\begin{array}{l}2^{\text {nd }} \text { step } \\
8.33 \mathrm{Si}+20 \mathrm{Mg}\left(\mathrm{BH}_{4}\right)_{2} \rightarrow \\
8.33 \mathrm{Mg}_{2} \mathrm{Si}+3.33 \mathrm{MgB}_{12} \mathrm{H}_{12}+60 \mathrm{H}_{2} \\
\end{array}$ & 2.759 & 43.62 & \\
\hline & $\begin{array}{l}\text { Entire reaction } \\
25 \mathrm{MgH}_{2}+\mathrm{NaMgH}_{3}+13 \mathrm{Mg}\left(\mathrm{NH}_{2}\right)_{2} \rightarrow \\
\mathrm{NaH}+13 \mathrm{Mg}_{3} \mathrm{~N}_{2}+52 \mathrm{H}_{2}\end{array}$ & 7.28 & & \\
\hline 6 & $\begin{array}{l}1^{\text {st }} \text { step } \\
25 \mathrm{MgH}_{2}+12.5 \mathrm{Mg}\left(\mathrm{NH}_{2}\right)_{2} \rightarrow \\
12.5 \mathrm{Mg}_{3} \mathrm{~N}_{2}+50 \mathrm{H}_{2}\end{array}$ & 6.996 & 26 & 5.3 \\
\hline & $\begin{array}{l}2^{\text {nd }} \text { step } \\
\mathrm{NaMgH}_{3}+0.5 \mathrm{Mg}\left(\mathrm{NH}_{2}\right)_{2} \rightarrow \\
\mathrm{NaH}+0.5 \mathrm{Mg}_{3} \mathrm{~N}_{2}+2 \mathrm{H}_{2}\end{array}$ & 0.28 & 31.3 & \\
\hline & $\begin{array}{l}\text { Entire reaction } \\
4 \mathrm{MgH}_{2}+47 \mathrm{Si}+108 \mathrm{Mg}\left(\mathrm{BH}_{4}\right)_{2} \rightarrow \\
47 \mathrm{Mg}_{2} \mathrm{Si}+18 \mathrm{MgB}_{12} \mathrm{H}_{12}+328 \mathrm{H}_{2}\end{array}$ & 9.11 & & \\
\hline 7 & $\begin{array}{l}1^{\text {st }} \text { step } \\
4 \mathrm{MgH}_{2}+2 \mathrm{Si} \rightarrow 2 \mathrm{Mg}_{2} \mathrm{Si}+4 \mathrm{H}_{2}\end{array}$ & 0.111 & 37.6 & 6.1 \\
\hline & $\begin{array}{l}2^{\text {nd }} \text { step } \\
45 \mathrm{Si}+108 \mathrm{Mg}\left(\mathrm{BH}_{4}\right)_{2} \rightarrow \\
45 \mathrm{Mg}_{2} \mathrm{Si}+18 \mathrm{MgB}_{12} \mathrm{H}_{12}+324 \mathrm{H}_{2}\end{array}$ & 9.002 & 43.6 & \\
\hline & $\begin{array}{l}\text { Entire reaction } \\
2 \mathrm{LiBH}_{4}+\mathrm{MgH}_{2}+7 \mathrm{Mg}\left(\mathrm{BH}_{4}\right)_{2}+3.83 \mathrm{Si} \rightarrow \\
3.83 \mathrm{Mg}_{2} \mathrm{Si}+\mathrm{Li}_{2} \mathrm{~B}_{12} \mathrm{H}_{12} \\
+0.33 \mathrm{MgB}_{12} \mathrm{H}_{12}+25 \mathrm{H}_{2}\end{array}$ & 9.07 & & \\
\hline & $\begin{array}{l}1^{\text {st }} \text { step } \\
\mathrm{MgH}_{2}+0.5 \mathrm{Si} \rightarrow 0.5 \mathrm{Mg}_{2} \mathrm{Si}+\mathrm{H}_{2}\end{array}$ & 0.363 & 37.6 & \\
\hline 8 & $\begin{array}{l}2^{\text {nd }} \text { step } \\
2 \mathrm{LiBH}_{4}+5 \mathrm{Mg}\left(\mathrm{BH}_{4}\right)_{2}+2.5 \mathrm{Si} \rightarrow \\
2.5 \mathrm{Mg}_{2} \mathrm{Si}+\mathrm{Li}_{2} \mathrm{~B}_{12} \mathrm{H}_{12}+18 \mathrm{H}_{2}\end{array}$ & 6.533 & 39.2 & 0.1 \\
\hline & $\begin{array}{l}3^{\text {rd }} \text { step } \\
2 \mathrm{Mg}\left(\mathrm{BH}_{4}\right)_{2}+0.83 \mathrm{Si} \rightarrow \\
0.83 \mathrm{Mg}_{2} \mathrm{Si}+0.33 \mathrm{MgB}_{12} \mathrm{H}_{12}+6 \mathrm{H}_{2}\end{array}$ & 2.178 & 43.6 & \\
\hline 9 & $\begin{array}{l}\text { Entire reaction } \\
\mathrm{MgH}_{2}+6 \mathrm{Mg}\left(\mathrm{BH}_{4}\right)_{2}+\mathrm{Ca}\left(\mathrm{BH}_{4}\right)_{2}+3.42 \mathrm{Si} \rightarrow\end{array}$ & 8.6 & & 6.1 \\
\hline
\end{tabular}




\begin{tabular}{|c|c|c|c|c|}
\hline & $\begin{array}{l}\text { 3.42- } \mathrm{Mg}_{2} \mathrm{Si}+0.17 \mathrm{MgB}_{12} \mathrm{H}_{12} \\
+\mathrm{CaB}_{12} \mathrm{H}_{12}+22 \mathrm{H}_{2}\end{array}$ & & & \\
\hline & $\begin{array}{l}1^{\text {st }} \text { step } \\
\mathrm{MgH}_{2}+0.5 \mathrm{Si} \rightarrow 0.5 \mathrm{Mg}_{2} \mathrm{Si}+\mathrm{H}_{2}\end{array}$ & 0.391 & 37.6 & \\
\hline & $\begin{array}{l}2^{\text {nd }} \text { step } \\
5 \mathrm{Mg}\left(\mathrm{BH}_{4}\right)_{2}+\mathrm{Ca}\left(\mathrm{BH}_{4}\right)_{2}+2.5 \mathrm{Si} \rightarrow \\
2.5 \mathrm{Mg}_{2} \mathrm{Si}+\mathrm{CaB}_{12} \mathrm{H}_{12}+18 \mathrm{H}_{2}\end{array}$ & 7.033 & 41.2 & \\
\hline & $\begin{array}{l}3^{\text {rd }} \text { step } \\
\mathrm{Mg}\left(\mathrm{BH}_{4}\right)_{2}+0.42 \mathrm{Si} \rightarrow \\
0.42 \mathrm{Mg}_{2} \mathrm{Si}+0.17 \mathrm{MgB}_{12} \mathrm{H}_{12}+3 \mathrm{H}_{2}\end{array}$ & 1.172 & 43.62 & \\
\hline & $\begin{array}{l}\text { Entire reaction } \\
46 \mathrm{LiBH}{ }_{4}+10 \mathrm{Mg}\left(\mathrm{BH}_{4}\right)_{2}+5 \mathrm{Si} \rightarrow \\
35 \mathrm{LiH}+5 \mathrm{Mg}_{2} \mathrm{Si}+5.5 \mathrm{Li}_{2} \mathrm{~B}_{12} \mathrm{H}_{12}+81.5 \mathrm{H}_{2}\end{array}$ & 9.77 & & \\
\hline 10 & $\begin{array}{l}1^{\text {st }} \text { step } \\
4 \mathrm{LiBH}_{4}+10 \mathrm{Mg}\left(\mathrm{BH}_{4}\right)_{2}+5 \mathrm{Si} \rightarrow \\
5 \mathrm{Mg}_{2} \mathrm{Si}+2 \mathrm{Li}_{2} \mathrm{~B}_{12} \mathrm{H}_{12}+36 \mathrm{H}_{2}\end{array}$ & 4.314 & 39.2 & 8 \\
\hline & $\begin{array}{l}2^{\text {nd }} \text { step } \\
42 \mathrm{LiBH}_{4} \rightarrow 35 \mathrm{LiH}+3.5 \mathrm{Li}_{2} \mathrm{~B}_{12} \mathrm{H}_{12}+45.5 \mathrm{H}_{2}\end{array}$ & 5.452 & 47.2 & \\
\hline & $\begin{array}{l}\text { Entire reaction } \\
12 \mathrm{LiBH}_{4}+\mathrm{MgH}_{2}+\mathrm{Mg}\left(\mathrm{BH}_{4}\right)_{2}+\mathrm{Si} \rightarrow \\
9.67 \mathrm{LiH}+\mathrm{Mg}_{2} \mathrm{Si}+1.17 \mathrm{Li}_{2} \mathrm{~B}_{12} \mathrm{H}_{12}+17.17 \mathrm{H}_{2}\end{array}$ & 9.36 & & \\
\hline & $\begin{array}{l}1^{\mathrm{st}} \text { step } \\
\mathrm{MgH}_{2}+0.5 \mathrm{Si} \rightarrow 0.5 \mathrm{Mg}_{2} \mathrm{Si}+\mathrm{H}_{2}\end{array}$ & 0.545 & 37.6 & \\
\hline 11 & $\begin{array}{l}2^{\text {nd }} \text { step } \\
0.4 \mathrm{LiBH}_{4}+\mathrm{Mg}\left(\mathrm{BH}_{4}\right)_{2}+0.5 \mathrm{Si} \rightarrow \\
0.5 \mathrm{Mg}_{2} \mathrm{Si}+0.2 \mathrm{Li}_{2} \mathrm{~B}_{12} \mathrm{H}_{12}+3.6 \mathrm{H}_{2}\end{array}$ & 1.963 & 39.2 & 9.6 \\
\hline & $\begin{array}{l}3^{\text {rd }} \text { step } \\
11.6 \mathrm{LiBH}_{4} \rightarrow \\
9.67 \mathrm{LiH}+0.97 \mathrm{Li}_{2} \mathrm{~B}_{12} \mathrm{H}_{12}+12.57 \mathrm{H}_{2}\end{array}$ & 6.851 & 47.16 & \\
\hline & $\begin{array}{l}\text { Entire reaction } \\
10 \mathrm{LiBH}_{4}+2 \mathrm{MgH}_{2}+\mathrm{Si} \rightarrow \\
8.33 \mathrm{LiH}+\mathrm{Mg}_{2} \mathrm{Si}+0.83 \mathrm{Li}_{2} \mathrm{~B}_{12} \mathrm{H}_{12}+12.83 \mathrm{H}_{2}\end{array}$ & 8.67 & & \\
\hline 12 & $\begin{array}{l}1^{\text {st }} \text { step } \\
2 \mathrm{MgH}_{2}+\mathrm{Si} \rightarrow \mathrm{Mg}_{2} \mathrm{Si}+2 \mathrm{H}_{2}\end{array}$ & 1.35 & 37.6 & 9.6 \\
\hline & $\begin{array}{l}2^{\text {nd }} \text { step } \\
10 \mathrm{LiBH}_{4} \rightarrow \\
8.33 \mathrm{LiH}+0.83 \mathrm{Li}_{2} \mathrm{~B}_{12} \mathrm{H}_{12}+10.83 \mathrm{H}_{2}\end{array}$ & 7.315 & 47.2 & \\
\hline & $\begin{array}{l}\text { II } \\
\text { tions having } 10 \mathrm{~kJ} / \mathrm{mol} \mathrm{H}_{2} \leq\left(\Delta \mathrm{G}_{\max }-\Delta G_{\mathrm{n}}\right.\end{array}$ & (n) & $/ \mathbf{m o l ~ H}_{2}$ & \\
\hline 1 & Entire reaction & 7 & & 12.6 \\
\hline
\end{tabular}




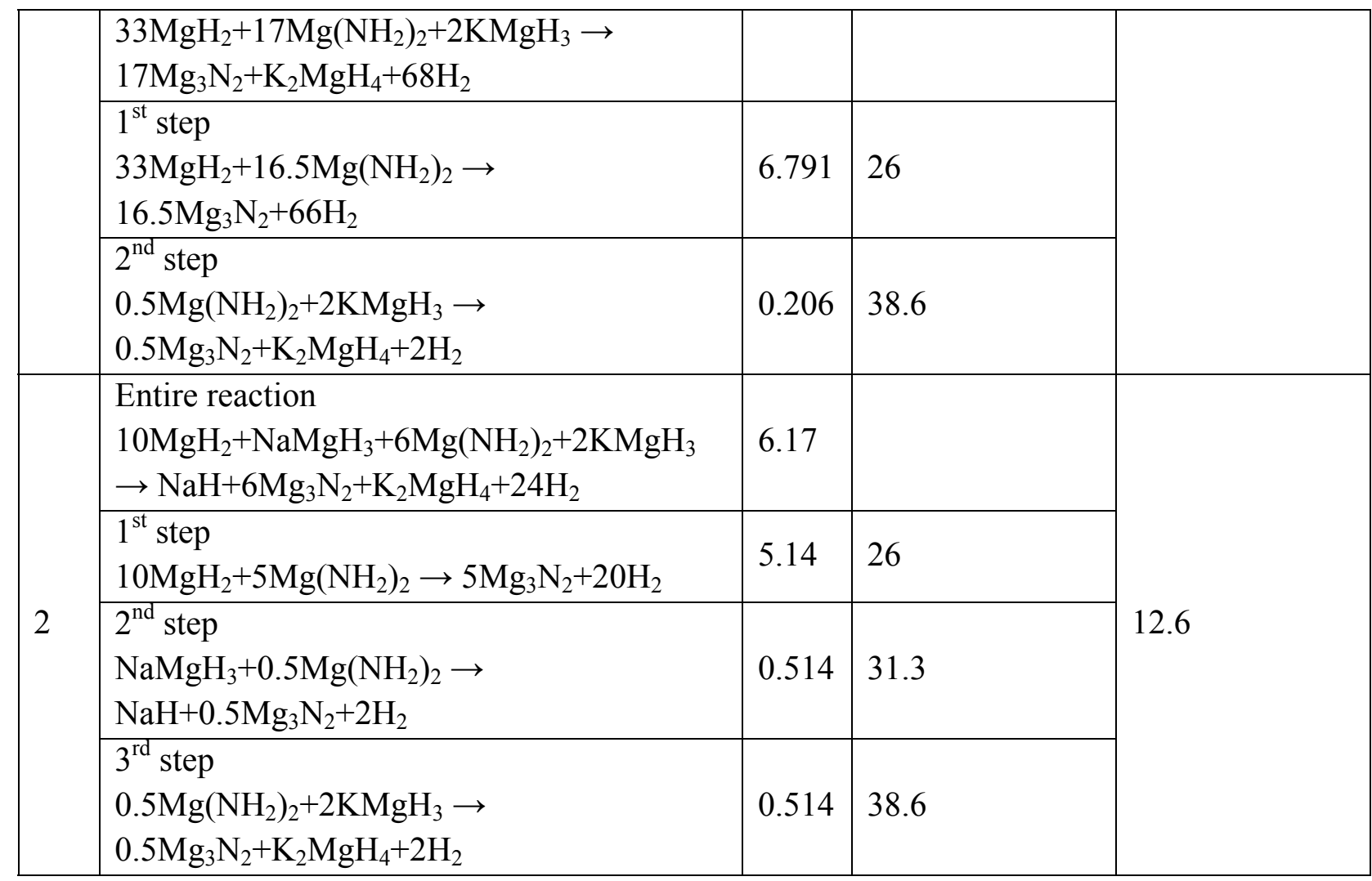

For convenience, the multi-step reactions in Table 3 are divided into three classes. Class I contains three multi-step reactions that do not involve any $\mathrm{B}_{12} \mathrm{H}_{12}$ species in which the difference in the calculated reaction energies between the first step and final step, $\Delta \mathrm{G}_{\max }-\Delta \mathrm{G}_{\min }$, is lower than $30 \mathrm{~kJ} / \mathrm{mol} \mathrm{H}_{2}$. This free energy includes entropy effects associated with site disorder in $\mathrm{KBH}_{4}$ and $\mathrm{NaBH}_{4}$ only, not entropy associated with the VDOS. Class II contains four multi-step reactions that do not involve any $\mathrm{B}_{12} \mathrm{H}_{12}$ species for which $\Delta \mathrm{G}_{\max }-\Delta \mathrm{G}_{\min }$ is larger than $30 \mathrm{~kJ} / \mathrm{mol}$ $\mathrm{H}_{2}$. Class I is thermodynamically more desirable for hydrogen storage than Class II because when $\Delta \mathrm{G}_{\max }-\Delta \mathrm{G}_{\min }$ is large, a broad range of temperatures would be required for all steps in the multi-step mechanism to be relevant. Class III contains two multi-step reactions that include $\mathrm{B}_{12} \mathrm{H}_{12}$ species and satisfy the screening criteria stated early. These reactions release relatively large amounts of $\mathrm{H}_{2}$ compared to the previous classes.

The seven multi-step reactions in Class I and Class II of Table 3 can be summarized by the two kinds of reaction schemes. The first scheme combines the destabilization reactions of $\mathrm{Mg}\left(\mathrm{NH}_{2}\right)_{2}$ by $\mathrm{MgH}_{2}, \mathrm{NaMgH}_{3}, \mathrm{KMgH}_{3}$, or $\mathrm{K}_{2} \mathrm{MgH}_{4}$. Two of the multi-step reactions in Table 3 are of this type. In these two reactions, the first step involves the combination of $\operatorname{Mg}\left(\mathrm{NH}_{2}\right)_{2}$ and $\mathrm{MgH}_{2}$. This single step reaction was identified above and in previous experimental and computational work..$^{19,24,66,71,72} \mathrm{~K}_{2} \mathrm{MgH}_{4}$ is the only compound connecting separate reaction steps in this scheme. In the second scheme, which accounts for five multi-step reactions, the first reaction is the decomposition and/or destabilization reaction of $\mathrm{Li}_{3} \mathrm{AlH}_{6}$, followed by destabilization reactions of $\mathrm{MgH}_{2}$. For example, the net reaction predicted from the initial 
mixture of $\mathrm{Li}_{3} \mathrm{AlH}_{6}$ and $\mathrm{MgH}_{2}$ with a ratio of 17:24 in Table 3 produces $\mathrm{LiH}$ and $\mathrm{Al}_{12} \mathrm{Mg}_{17}$ with a $\mathrm{H}_{2}$ release of $6.45 \mathrm{wt} . \%$ and $\Delta \mathrm{G}_{\max }-\Delta \mathrm{G}_{\min }$ of $30.3 \mathrm{~kJ} / \mathrm{mol} \mathrm{H}_{2}$ via three single step reactions. The first step is the decomposition reaction of $\mathrm{Li}_{3} \mathrm{AlH}_{6}$ forming $\mathrm{LiH}$ and $\mathrm{Al}$ with a $\mathrm{H}_{2}$ release of 3.323 wt.\%. The second step is the destabilization reaction of $\mathrm{MgH}_{2}$ by $\mathrm{Al}$ which is produced from the first step, forming $\mathrm{Al}_{30} \mathrm{Mg}_{23}$ with a $\mathrm{H}_{2}$ release of $1.698 \mathrm{wt} . \%$. The third step is the destabilization reaction of $\mathrm{MgH}_{2}$ by $\mathrm{Al}_{30} \mathrm{Mg}_{23}$ which is produced from the second step, forming $\mathrm{Al}_{12} \mathrm{Mg}_{17}$ with a $\mathrm{H}_{2}$ release of 1.429 wt.\%.

The multi-step reactions in Table 4 are divided into two classes. Class I contains twelve multi-step reactions in which $\Delta \mathrm{G}_{\max }-\Delta \mathrm{G}_{\min }$ is lower than $10 \mathrm{~kJ} / \mathrm{mol} \mathrm{H}_{2}$. Class II contains two multi-step reactions in which $\Delta \mathrm{G}_{\max }-\Delta \mathrm{G}_{\min }$ is between $10 \mathrm{~kJ} / \mathrm{mol} \mathrm{H} \mathrm{H}_{2}$ and $20 \mathrm{~kJ} / \mathrm{mol} \mathrm{H}$. They have the relatively low values of $\Delta \mathrm{G}_{\max }-\Delta \mathrm{G}_{\min }$ compared to the multi-step reactions in Table 3 , but most of them involve $\mathrm{B}_{12} \mathrm{H}_{12}$ species which appear to be undesirable for reversible hydrogen storage applications because of their kinetic stability. Basically, the multi-step reactions in Table 4 are the combination of two or more initial mixtures that have separate reaction paths. For example, the net reaction of the initial mixture of $\mathrm{LiBH}_{4}, \mathrm{MgH}_{2}$, and $\mathrm{Si}$ with the ratio of 10:2:1 in Table 4 produces $\mathrm{LiH}, \mathrm{Mg}_{2} \mathrm{Si}$, and $\mathrm{Li}_{2} \mathrm{~B}_{12} \mathrm{H}_{12}$ with a $\mathrm{H}_{2}$ release of $8.67 \mathrm{wt} . \%$ and $\Delta \mathrm{G}_{\max }-\Delta \mathrm{G}_{\min }$ of $9.6 \mathrm{~kJ} / \mathrm{mol} \mathrm{H}_{2}$ via two single step reactions. The first step is the reaction between $\mathrm{MgH}_{2}$ and Si to form $\mathrm{Mg}_{2} \mathrm{Si}$ with a $\mathrm{H}_{2}$ release of $1.35 \mathrm{wt} . \%$ and the second step is the decomposition reaction of $\mathrm{LiBH}_{4}$ to form $\mathrm{LiH}$ and $\mathrm{Li}_{2} \mathrm{~B}_{12} \mathrm{H}_{12}$ with a $\mathrm{H}_{2}$ release of 7.315 wt.\%.

\section{Recommendations}

Several promising reactions have been identified in our computational approach. The reaction $\mathrm{LiH}+2 \mathrm{LiNH}_{2}+\mathrm{KBH}_{4} \rightarrow \mathrm{Li}_{3} \mathrm{BN}_{2}+\mathrm{KH}+4 \mathrm{H}_{2}$ appears to be especially promising and should be investigated experimentally. In addition, several multi-step reactions should be investigated experimentally.

\section{Lessons learned from the Center approach}

The MHCoE has provided a unique opportunity for close collaboration between experimental and theory groups. This free exchange of information has given rise to better work than could be accomplished by groups working individually. Free and frequent communication is essential for success.

\section{References}

(1) Bogdanovic, B.; Schwickardi, M. J. Alloys Compd. 1997, 253-254, 1.

(2) Wang, J.; Ebner, A. D.; Ritter, J. A. J. Am. Chem. Soc. 2006, 128, 5949. 
(3) Fichtner, M.; Fuhr, O.; Kircher, O. J. Alloys Compd. 2003, 356-357, 418.

(4) Vajo, J. J.; Skeith, S. L.; Mertens, F. J. Phys. Chem. B 2005, 109, 3719.

(5) Zuttel, A.; Rentsch, S.; Fischer, P.; Wenger, P.; Sudan, P.; Mauron, P.; Emmenegger, C. J. Alloys Compd. 2003, 356-357, 515.

(6) Li, H.-W.; Kikuchi, K.; Nakamori, Y.; N.Ohba; Miwa, K.; Towata, S.; Orimo, S. Acta Mater. 2008, 56, 1342.

(7) Kim, J.-H.; Jin, S.-A.; Shim, J.-H.; Cho, Y. W. Scripta Mater. 2008, 58, 481.

(8) Chen, P.; Xiong, Z.; Luo, J.; Lin, J.; Tan, K. L. Nature 2002, 420, 302.

(9) Lu, J.; Fang, Z. Z. J. Phys. Chem. B 2005, 109, 20830.

(10) Soloveichik, G.; Her, J.-H.; Stephens, P. W.; Gao, Y.; Rijssenbeek, J.; Andrus, M.; Zhao, J.-C. Inorg. Chem. 2008, 47, 4290.

(11) Nickels, E. A.; Jones, N. O.; David, W. I. F.; Johnson, S. R.; Lowton, R. L.; Sommariva, M.; Edwards, P. P. Angew. Chem. Int. Ed. 2008, 47, 2817.

(12) Kim, K. C.; Dai, B.; Johnson, J. K.; Sholl, D. S. Nanotechnology 2009, 20, 204001.

(13) Vajo, J. J.; Mertens, F.; Ahn, C. C.; Robert C. Bowman, J.; Fultz, B. J. Phys. Chem. B 2004, 108, 13977.

(14) Ibikunle, A.; Goudy, A. J.; Yang, H. J. Alloys Compd. 2009, 475, 110.

(15) Vittetoe, A. W.; Niemann, M. U.; Srinivasan, S. S.; McGrath, K.; Kumar, A.; Goswami, D. Y.; Stefanakos, E. K.; Thomas, S. Int. J. Hydrogen Energy 2009, 34, 2333.

(16) Alapati, S. V.; Johnson, J. K.; Sholl, D. S. J. Alloys Compd. 2007, 446, 23.

(17) Alapati, S. V.; Johnson, J. K.; Sholl, D. S. J. Phys. Chem. C 2007, 111, 1584.

(18) Alapati, S. V.; Johnson, J. K.; Sholl, D. S. Phys. Chem. Chem. Phys. 2007, 9, 1438 .

(19) Akbarzadeh, A. R.; Ozolinš, V.; Wolverton, C. Adv. Mater. 2007, 19, 3233.

(20) Akbarzadeh, A. R.; Wolverton, C.; Ozolins, V. Phys. Rev. B 2009, 79, 184102.

(21) Michel, K. J.; Akbarzadeh, A. R.; Ozolins, V. J. Phys. Chem. C 2009, 113, 14551. 
(22) Ozolins, V.; Majzoub, E. H.; Wolverton, C. J. Am. Chem. Soc. 2009, 131, 230.

(23) Alapati, S. V.; Johnson, J. K.; Sholl, D. S. J. Phys. Chem. C 2008, 112, 5258.

(24) Wolverton, C.; Siegel, D. J.; Akbarzadeh, A. R.; Ozolins, V. J. Phys.: Condens. Matter 2008, 20, 064228.

(25) Her, J. H.; Yousufuddin, M.; Zhou, W.; Jalisatgi, S. S.; Kulleck, J. G.; Zan, J. A.; Hwang, S. J.; Robert C. Bowman, J.; Udovic, T. J. Inorganic Chemistry 2008, 47, 9757.

(26) Hwang, S. J.; Robert C. Bowman, J.; Reiter, J. W.; Rijssenbeek, J.; Soloveichik, G. L.; Zhao, J. C.; Kabbour, H.; Ahn, C. C. J. Phys. Chem. C 2008, 112, 3164.

(27) Kim, C.; Hwang, S.-J.; Robert C. Bowman, J.; Reiter, J. W.; Zan, J. A.; Kulleck, J. G.; Kabbour, H.; Majzoub, E. H.; Ozolins, V. J. Phys. Chem. C 2009, 113, 9956.

(28) Li, H. W.; Miwa, K.; Ohba, N.; Fujita, T.; Sato, T.; Yan, Y.; Towata, S.; Chen, M. W.; Orimo, S. Nanotechnology 2009, 20, 204013.

(29) Kim, K. C.; Sholl, D. S. J. Phys. Chem. C 2010, 114, 678.

(30) Alapati, S. V.; Johnson, J. K.; Sholl, D. S. J. Phys. Chem. B 2006, 110, 8769.

(31) Perdew, J. P.; Chevary, J. A.; Vosko, S. H.; Jackson, K. A.; Pederson, M. R.; Singh, D. J.; Fiolhais, C. Phys. Rev. B 1992, 46, 6671.

(32) Kresse, G.; Furthmuller, J. Phys. Rev. B 1996, 54, 11169.

(33) Kresse, G.; Hafner, J. Phys. Rev. B 1993, 47, 558.

(34) Vanderbilt, D. Phys. Rev. B 1990, 41, 7892.

(35) Kresse, G.; Joubert, D. Phys. Rev. B 1999, 59, 1758.

(36) The Inorganic Crystal Structure Database (ICSD), http://www.fizinformationsdienste.de/en/DB/icsd/.

(38) Kim, J.-H.; Jin, S.-A.; Shim, J.-H.; Cho, Y. W. J. Alloys Compd. 2008, 461, L20.

(39) Aoki, M.; Miwa, K.; Noritake, T.; Ohba, N.; Matsumoto, M.; Li, H.-W.; Nakamori, Y.; Towata, S.; Orimo, S. Appl. Phys. A 2008, 92, 601. 
(40) Wang, L.-L.; Graham, D. D.; Robertson, I. M.; Johnson, D. D. J. Phys. Chem. C 2009, 113, 20088.

(41) Soloveichik, G. L.; Andrusa, M.; Gaoa, Y.; Zhao, J. C.; Kniajanski, S. Inter. J. Hydrogen Energy 2009, 34, 2144.

(42) Fang, Z.-Z.; Kang, X.-D.; Wang, P.; Li, H.-W.; Orimo, S.-I. J. Alloys Compd. 2010, 491, L1.

(43) Friedrichs, O.; Kim, J. W.; Remhof, A.; Buchter, F.; Borgschulte, A.; Wallacher, D.; Cho, Y. W.; Fichtner, M.; Oh, K. H.; Züttel, A. Phys. Chem. Chem. Phys. 2009, 11, 1515.

(44) Cahen, S.; Eymery, J. B.; Janot, R.; Tarascon, J. M. J. Power Sources 2009, 189, 902.

(45) Hanada, N.; Chlopek, K.; Frommen, C.; Lohstroh, W.; Fichtner, M. J. Mater. Chem. 2008, 18, 2611.

(46) Kulkarni, A. D.; Wang, L.-L.; Johnson, D.; Sholl, D. S.; Johnson, K. submitted to J. Phys. Chem. C.

(47) Dyachkov, L. G.; Zhilyakov, L. A.; Kostanovskii, A. V. Tech. Phys. 2000, 45, 115.

(48) Nakano, K.; Matsubara, H.; Imura, T. Jpn. J. Appl. Phys. 1974, 13, 1005.

(49) Hao, X. P.; Cui, D. L.; Shi, G. X.; Yin, Y. Q.; Xu, X. G.; Jiang, M. H.; Xu, X. W.; Li, Y. P. Mater. Lett. 2001, 51, 509.

(50) Levchenko, G.; Lyashchenko, A.; Baumer, V.; Evdokimova, A.; Filippov, V. J. Solid State Chem. 2006, 179, 2949.

(51) Matrosov, Y. I.; Anashenko, V. N. Metal Science and Heat Treatment 1971, 13, 893.

(52) Lin, Z.; Guanghui, M.; Huashun, Y. Ceram. Int. 2009, 35, 3533.

(53) Christensen, A. N. Acta Cryst. B 1979, 35, 2677.

(54) Siegel, D. J.; Wolverton, C.; Ozolinšs, V. Phys. Rev. B 2007, 76, 134102.

(55) Purewal, J.; Hwang, S. J.; Robert C. Bowman, J.; Rnnebro, E.; Fultz, B.; Ahn, C. J. Phys. Chem. C 2008, 112, 8481. 
Yang, J.; Sudik, A.; Wolverton, C. J. Phys. Chem. C 2007, 111, 19134.

(57)

Kim, K. C.; Allendorf, M. D.; Stavila, V.; Sholl, D. S. Phys. Chem. Chem. Phys., in press.

Gross, A. F.; Vajo, J. J.; Van Atta, S. L.; Olson, G. L. J. Phys. Chem. C 2008, 112,5651 .

(59) Berseth, P. A.; Harter, A. G.; Zidan, R.; Blomqvist, A.; Araujo, C. M.; Scheicher, R. H.; Ahuja, R.; Jena, P. Nano Lett. 2009, 9, 1501.

(60) Fang, Z. Z.; Wang, P.; Rufford, T. E.; Kang, X. D.; Lu, G. Q.; Cheng, H. M. Acta Mater. 2008, 56, 6257.

(61) Campesi, R.; Cuevas, F.; Leroy, E.; Hirscher, M.; Gadiou, R.; Vix-Guterl, C.; Latroche, M. Micropor. Mesopor. Mat. 2009, 117, 511.

(62) Zhang, Y.; Zhang, W.-S.; Wang, A.-Q.; Sun, L.-X.; Fan, M.-Q.; Chu, H.-L.; Zhang, J.-C. S. T. Int. J. Hydrogen Energy 2007, 32, 3976.

(63) Wang, P.; Wang, A. M.; Wang, Y. L.; Zhang, H. F.; Hu, Z. Q. Scripta Mater. 2000, 43, 83 .

(64) Vajo, J. J.; Olson, G. L. Scripta Mater. 2007, 56, 829.

(65) Malka, I. E.; Czujko, T.; Bystrzycki, J. Int. J. Hydrogen Energy 2010, 35, 1706.

(66) Hu, J.; Wu, G.; Liu, Y.; Xiong, Z.; Chen, P.; Murata, K.; Sakata, K.; Wolf, G. J. Phys. Chem. B 2006, 110, 14688.

(67) Alapati, S. V.; Johnson, J. K.; Sholl, D. S. Phys. Rev. B 2007, 76, 104108.

(68) Soulié, J. P.; Renaudin, G.; Cerny, R.; Yvon, K. J. Alloys Compd. 2002, 346, 200.

(69) Gomes, S.; Hagemann, H.; Yvon, K. J. Alloys Compd. 2002, 346, 206.

(70) Skripov, A. V.; Soloninin, A. V.; Filinchuk, Y.; Chernyshov, D. J. Phys. Chem. C 2008, 112, 18701.

(71) Chen, P.; Xiong, Z.; Wu, G.; Liu, Y.; Hu, J.; Luo, W. Scripta Mater. 2007, 56, 817.

(72) Araújo, C. M.; Scheicher, R. H.; Ahuja, R. Appl. Phys. Lett. 2008, 92, 021907. 



\section{Appendix A}

\section{List of Peer Reviewed Publications}

1. The role of interstitial $\mathrm{H} 2$ in hydrogen diffusion in light metal borohydrides, Shiqiang Hao and David S. Sholl, Phys. Chem. Chem. Phys., 11, 11106-11109 (2009)

2. Crystal structures and thermodynamic investigations of $\mathrm{LiK}(\mathrm{BH} 4) 2, \mathrm{KBH} 4$, and NaBH4 from first-principles calculations, Ki Chul Kim and David S. Sholl, J. Phys. Chem. C, 114, 678-686 (2010)

3. Predicting Impurity Gases and Phases During Hydrogen Evolution from Complex Metal Hydrides using Free Energy Minimization Enabled by First-principles Calculations, Ki Chul Kim, Mark D. Allendorf, Vitalie Stavila, and David S. Sholl, submitted to PCCP.

4. Ki Chul Kim, Anant D. Kulkarni, J. Karl Johnson, and David S. Sholl, "Large-scale screening of promising metal hydrides for hydrogen storage system from first-principles calculations based on equilibrium reaction thermodynamics", Journal of Physical Chemistry C, submitted, (2010).

5. Anant D. Kulkarni, Lin-Lin Wang, Duane D. Johnson, David S. Sholl, and J. Karl Johnson, "First-Principles Characterization of Amorphous Phases of $\mathrm{MB}_{12} \mathrm{H}_{12}, \mathrm{M}=\mathrm{Mg}$, Ca”, Journal of Physical Chemistry C, 114, 14601-14605, (2010).

6. Ki Chul Kim, Bing Dai, J. Karl Johnson and David S. Sholl, "Assessing nanoparticle size effects on metal hydride thermodynamics using the Wulff construction", Nanotechnology, 20, 204001 (2009).

7. Bing Dai, Rees B. Rankin, J. Karl Johnson, Mark D. Allendorf, David S. Sholl, Nikolai A. Zarkevich and Duane D. Johnson, "Influence of Surface Reactions on Complex Hydride Reversibility", Journal of Physical Chemistry C, 112, 18270-18279 (2008).

8. Sudhakar V. Alapati, J. Karl Johnson, and David S. Sholl, "Large-Scale Screening of Metal Hydride Mixtures for High-Capacity Hydrogen Storage from First-Principles Calculations", Journal of Physical Chemistry C, 112, 5258-5262 (2008).

9. Bing Dai, David S. Sholl, and J. Karl Johnson, "First Principles Study of Experimental and Hypothetical $\mathrm{Mg}\left(\mathrm{BH}_{4}\right)_{2}$ Crystal Structures", Journal of Physical Chemistry C, 112, 4391-4395 (2008).

10. Sudhakar V. Alapati, J. Karl Johnson, and David S. Sholl, "Stability analysis of doped materials for reversible hydrogen storage in destabilized metal hydrides", Physical Review B, 76, 104108 (2007).

11. Bing Dai, David S. Sholl, and J. Karl Johnson, "First Principles Investigation of Adsorption and Dissociation of Hydrogen on $\mathrm{Mg}_{2}$ Si Surfaces", Journal of Physical Chemistry C, 111, 6910-6916 (2007).

12. Sudhakar V. Alapati, J. Karl Johnson, and David S. Sholl, "Using First Principles Calculations To Identify New Destabilized Metal Hydride Reactions for Reversible Hydrogen Storage”, Phys. Chem. Chem. Phys. 9, 1438-1452 (2007).

13. Sudhakar V. Alapati, J. Karl Johnson, and David S. Sholl, "First principles screening of 
destabilized metal hydrides for high capacity $\mathrm{H}_{2}$ storage using scandium", Journal of Alloys and Compounds 446-447, 23-27 (2007).

14. Sudhakar V. Alapati, J. Karl Johnson, and David S. Sholl, "Predicting Reaction Equilibria for Destabilized Metal Hydride Decomposition Reactions for Reversible Hydrogen Storage", Journal of Physical Chemistry C 111, 1584-1591 (2007).

15. Sudhakar V. Alapati, J. Karl Johnson, and David S. Sholl "Identification of Destabilized Metal Hydrides for Hydrogen Storage Using First Principles Calculations", Journal of Physical Chemistry B, 110, 8769-8776 (2006).

\section{Appendix B}

\section{Final data tables for all materials investigated}

Table A1. List of 359 compounds included in our database.

\begin{tabular}{|c|c|c|c|c|}
\hline \multicolumn{5}{|c|}{ One-element compounds } \\
\hline $\mathrm{Al}$ & $\mathrm{B}$ & $\mathrm{C}$ & $\mathrm{Ca}$ & $\mathrm{K}$ \\
\hline $\mathrm{Li}$ & $\mathrm{Mg}$ & $\mathrm{Na}$ & $\mathrm{Sc}$ & $\mathrm{Si}$ \\
\hline $\mathrm{Ti}$ & $\mathrm{V}$ & & & \\
\hline \multicolumn{5}{|c|}{ Two-element compounds } \\
\hline $\mathrm{AlB}_{2}$ & $\mathrm{AlB}_{12}$ & $\mathrm{Al}_{4} \mathrm{C}_{3}$ & $\mathrm{Al}_{2} \mathrm{Ca}$ & $\mathrm{Al}_{4} \mathrm{Ca}$ \\
\hline $\mathrm{AlH}_{3}$ & $\mathrm{AlLi}$ & $\mathrm{Al}_{2} \mathrm{Li}_{3}$ & $\mathrm{Al}_{3} \mathrm{Li}$ & $\mathrm{Al}_{4} \mathrm{Li}_{9}$ \\
\hline $\mathrm{Al}_{12} \mathrm{Mg}_{17}$ & $\mathrm{Al}_{14} \mathrm{Mg}_{13}$ & $\mathrm{Al}_{30} \mathrm{Mg}_{23}$ & AlN & AlSc \\
\hline $\mathrm{AlSc}_{2}$ & $\mathrm{Al}_{2} \mathrm{Sc}$ & $\mathrm{Al}_{3} \mathrm{Sc}$ & AlTi & $\mathrm{AlTi}_{3}$ \\
\hline $\mathrm{Al}_{2} \mathrm{Ti}$ & $\mathrm{Al}_{3} \mathrm{Ti}$ & $\mathrm{AlV}$ & $\mathrm{AlV}_{3}$ & $\mathrm{Al}_{3} \mathrm{~V}$ \\
\hline $\mathrm{Al}_{10} \mathrm{~V}$ & $\mathrm{Al}_{23} \mathrm{~V}_{4}$ & $\mathrm{Al}_{45} \mathrm{~V}_{7}$ & $\mathrm{~B}_{4} \mathrm{C}$ & $\mathrm{B}_{13} \mathrm{C}_{2}$ \\
\hline $\mathrm{B}_{3} \mathrm{Ca}_{4} \mathrm{LiN}_{6}$ & $\left(\mathrm{~B}_{10} \mathrm{H}_{13}\right)_{2}$ & $\mathrm{BN}$ & $\mathrm{B}_{13} \mathrm{~N}_{2}$ & $\mathrm{C}_{2} \mathrm{Ca}$ \\
\hline $\mathrm{C}_{2} \mathrm{~N}_{2}$ & $\mathrm{C}_{3} \mathrm{~N}_{4}$ & $\mathrm{C}_{5} \mathrm{~N}_{4}$ & $\mathrm{C}_{12} \mathrm{~N}_{6}$ & $\mathrm{CaB}_{4}$ \\
\hline $\mathrm{CaB}_{6}$ & $\mathrm{CaH}_{2}$ & $\mathrm{CaLi}_{2}$ & $\mathrm{CaMg}_{2}$ & $\mathrm{CaN}_{6}$ \\
\hline $\mathrm{Ca}_{2} \mathrm{~N}$ & $\mathrm{Ca}_{3} \mathrm{~N}_{2}$ & $\mathrm{Ca}_{11} \mathrm{~N}_{8}$ & $\mathrm{CaSi}$ & $\mathrm{CaSi}_{2}$ \\
\hline $\mathrm{Ca}_{2} \mathrm{Si}$ & $\mathrm{Ca}_{5} \mathrm{Si}_{3}$ & $\mathrm{~KB}_{6}$ & $\mathrm{KC}_{8}$ & $\mathrm{~K}_{2} \mathrm{C}_{2}$ \\
\hline KH & $\mathrm{KN}_{3}$ & $\mathrm{~K}_{3} \mathrm{~N}$ & $\mathrm{KSi}$ & $\mathrm{K}_{4} \mathrm{Si}_{4}$ \\
\hline $\mathrm{K}_{8} \mathrm{Si}_{46}$ & $\mathrm{LiB}$ & $\mathrm{Li}_{5} \mathrm{~B}_{4}$ & $\mathrm{Li}_{2} \mathrm{C}_{2}$ & $\mathrm{LiH}$ \\
\hline LiMg & $\mathrm{LiN}_{3}$ & $\mathrm{Li}_{3} \mathrm{~N}$ & LiSi & $\mathrm{Li}_{2} \mathrm{Si}$ \\
\hline $\mathrm{Li}_{7} \mathrm{Si}_{2}$ & $\mathrm{Li}_{12} \mathrm{Si}_{7}$ & $\mathrm{Li}_{13} \mathrm{Si}_{4}$ & $\mathrm{Li}_{15} \mathrm{Si}_{4}$ & $\mathrm{MgB}_{2}$ \\
\hline $\mathrm{MgB}_{4}$ & $\mathrm{MgB}_{7}$ & $\mathrm{MgC}_{2}$ & $\mathrm{Mg}_{2} \mathrm{C}_{3}$ & $\mathrm{MgH}_{2}$ \\
\hline $\mathrm{Mg}_{3} \mathrm{~N}_{2}$ & $\mathrm{MgSc}$ & $\mathrm{Mg}_{2} \mathrm{Si}$ & $\mathrm{Mg}_{5} \mathrm{Si}_{6}$ & $\mathrm{~N}_{4} \mathrm{Si}_{3}$ \\
\hline $\mathrm{NaB}_{15}$ & $\mathrm{Na}_{3} \mathrm{~B}_{20}$ & $\mathrm{Na}_{2} \mathrm{C}_{2}$ & $\mathrm{NaH}$ & $\mathrm{NaN}_{3}$ \\
\hline $\mathrm{Na}_{3} \mathrm{~N}$ & $\mathrm{NaSi}$ & $\mathrm{Na}_{4} \mathrm{Si}_{4}$ & $\mathrm{Na}_{8} \mathrm{Si}_{46}$ & $\mathrm{ScB}_{2}$ \\
\hline $\mathrm{ScB}_{12}$ & $\mathrm{ScC}$ & $\mathrm{Sc}_{2} \mathrm{C}$ & $\mathrm{Sc}_{2} \mathrm{C}_{3}$ & $\mathrm{Sc}_{3} \mathrm{C}_{4}$ \\
\hline $\mathrm{Sc}_{4} \mathrm{C}_{3}$ & $\mathrm{Sc}_{15} \mathrm{C}_{19}$ & $\mathrm{ScH}_{2}$ & $\mathrm{ScN}$ & $\mathrm{ScSi}$ \\
\hline
\end{tabular}




\begin{tabular}{|c|c|c|c|c|}
\hline $\mathrm{ScSi}_{2}$ & $\mathrm{Sc}_{5} \mathrm{Si}_{3}$ & $\mathrm{SiB}_{3}$ & $\mathrm{SiB}_{6}$ & $\mathrm{SiC}$ \\
\hline $\mathrm{SiH}$ & TiB & $\mathrm{TiB}_{2}$ & TiC & $\mathrm{Ti}_{2} \mathrm{C}$ \\
\hline $\mathrm{Ti}_{8} \mathrm{C}_{5}$ & $\mathrm{TiH}$ & $\mathrm{TiH}_{2}$ & TiN & $\mathrm{Ti}_{2} \mathrm{~N}$ \\
\hline TiSi & $\mathrm{TiSi}_{2}$ & $\mathrm{Ti}_{5} \mathrm{Si}_{3}$ & $\mathrm{Ti}_{5} \mathrm{Si}_{4}$ & $\mathrm{TiV}$ \\
\hline VB & $\mathrm{VB}_{2}$ & $\mathrm{~V}_{2} \mathrm{~B}_{3}$ & $\mathrm{~V}_{3} \mathrm{~B}_{2}$ & $\mathrm{VC}$ \\
\hline $\mathrm{V}_{2} \mathrm{C}$ & $\mathrm{V}_{6} \mathrm{C}_{5}$ & $\mathrm{~V}_{8} \mathrm{C}_{7}$ & $\mathrm{VH}_{2}$ & $\mathrm{~V}_{2} \mathrm{H}$ \\
\hline $\mathrm{VN}$ & $\mathrm{V}_{2} \mathrm{~N}$ & $\mathrm{VSi}_{2}$ & $\mathrm{~V}_{3} \mathrm{Si}$ & $\mathrm{V}_{5} \mathrm{Si}_{3}$ \\
\hline \multicolumn{5}{|l|}{$\mathrm{V}_{6} \mathrm{Si}_{5}$} \\
\hline \multicolumn{5}{|c|}{ Three-element compounds } \\
\hline $\mathrm{Al}\left(\mathrm{BH}_{4}\right)_{3}$ & $\mathrm{Al}_{5} \mathrm{C}_{3} \mathrm{~N}$ & $\mathrm{Al}_{6} \mathrm{C}_{3} \mathrm{~N}_{2}$ & $\mathrm{Al}_{7} \mathrm{C}_{3} \mathrm{~N}_{3}$ & $\mathrm{Al}_{8} \mathrm{C}_{3} \mathrm{~N}_{4}$ \\
\hline $\mathrm{Al}_{2} \mathrm{Ca}_{3} \mathrm{~N}_{4}$ & $\mathrm{Al}_{2} \mathrm{CaSi}_{2}$ & $\mathrm{Al}_{2} \mathrm{Ca}_{3} \mathrm{Si}_{2}$ & $\mathrm{AlLi}_{3} \mathrm{~N}_{2}$ & AlLiSi \\
\hline $\mathrm{Al}_{3} \mathrm{Li}_{8} \mathrm{Si}_{5}$ & $\mathrm{Al}_{3} \mathrm{Li}_{12} \mathrm{Si}_{4}$ & $\mathrm{Al}_{2} \mathrm{MgC}_{2}$ & $\mathrm{AlMg}_{4} \mathrm{Si}_{6}$ & $\mathrm{Al}_{18} \mathrm{Mg}_{3} \mathrm{Ti}_{2}$ \\
\hline $\mathrm{AlSc}_{2} \mathrm{Si}_{2}$ & $\mathrm{BC}_{2} \mathrm{~N}$ & $\mathrm{C}_{2} \mathrm{H}_{4} \mathrm{~N}_{4}$ & $\mathrm{C}_{2} \mathrm{H}_{18} \mathrm{~N}_{18}$ & $\mathrm{C}_{2} \mathrm{~N}_{2}(\mathrm{NH})$ \\
\hline $\mathrm{CaAlH}_{5}$ & $\mathrm{Ca}\left(\mathrm{AlH}_{4}\right)_{2}$ & $\mathrm{Ca}_{4} \mathrm{Al}_{3} \mathrm{Mg}$ & $\mathrm{Ca}_{3} \mathrm{AlN}_{3}$ & CaAlSi \\
\hline $\mathrm{CaB}_{2} \mathrm{C}_{2}$ & $\mathrm{Ca}\left(\mathrm{BH}_{4}\right)_{2}$ & $\mathrm{CaB}_{12} \mathrm{H}_{12}$ & $\mathrm{Ca}_{3} \mathrm{BN}_{3}$ & $\mathrm{CaCN}_{2}$ \\
\hline $\mathrm{CaC}_{4} \mathrm{~N}_{6}$ & $\mathrm{Ca}_{2} \mathrm{HN}$ & CaLiN & $\mathrm{CaLiSi}_{2}$ & $\mathrm{Ca}_{2} \mathrm{LiSi}_{3}$ \\
\hline $\mathrm{CaMg}_{2} \mathrm{~N}_{2}$ & $\mathrm{CaMgSi}$ & $\mathrm{Ca}_{4} \mathrm{~N}_{2}\left(\mathrm{CN}_{2}\right)$ & $\mathrm{Ca}_{11} \mathrm{~N}_{6}\left(\mathrm{CN}_{2}\right)_{2}$ & $\mathrm{Ca}_{2} \mathrm{~N}_{3} \mathrm{~V}$ \\
\hline $\mathrm{Ca}_{3} \mathrm{~N}_{3} \mathrm{~V}$ & $\mathrm{CaSiN}_{2}$ & $\mathrm{Ca}_{2} \mathrm{Si}_{5} \mathrm{~N}_{8}$ & $\mathrm{Ca}_{5}\left(\mathrm{Si}_{2} \mathrm{~N}_{6}\right)$ & $\mathrm{Ca}_{4} \mathrm{TiN}_{4}$ \\
\hline $\mathrm{H}_{9} \mathrm{CN}_{9}$ & $\mathrm{KAlH}_{4}$ & $\mathrm{~K}_{3} \mathrm{AlH}_{6}$ & $\mathrm{KBH}_{4}$ & $\mathrm{~KB}_{21} \mathrm{H}_{18}$ \\
\hline $\mathrm{K}_{2} \mathrm{~B}_{6} \mathrm{H}_{6}$ & $\mathrm{~K}_{2}\left(\mathrm{~B}_{10} \mathrm{H}_{10}\right)$ & $\mathrm{K}_{2} \mathrm{~B}_{12} \mathrm{H}_{12}$ & $\mathrm{KCN}$ & $\mathrm{KC}_{2} \mathrm{~N}_{3}$ \\
\hline $\mathrm{KC}_{4} \mathrm{~N}_{3}$ & $\mathrm{~K}_{2} \mathrm{CN}_{2}$ & $\mathrm{~K}_{3} \mathrm{C}_{6} \mathrm{~N}_{9}$ & $\mathrm{~K}_{3} \mathrm{LiSi}_{4}$ & $\mathrm{~K}_{7} \mathrm{LiSi}_{8}$ \\
\hline $\mathrm{KMgH}_{3}$ & $\mathrm{~K}_{2} \mathrm{MgH}_{4}$ & $\mathrm{KNH}_{2}$ & $\left(\mathrm{~K}\left(\mathrm{NH}_{2}\right)\right)\left(\mathrm{NH}_{3}\right)_{2}$ & $\mathrm{KSiH}_{3}$ \\
\hline $\mathrm{LiAlB}_{14}$ & $\mathrm{LiAlH}_{4}$ & $\mathrm{Li}_{3} \mathrm{AlH}_{6}$ & LiBC & $\mathrm{LiB}_{13} \mathrm{C}_{2}$ \\
\hline $\mathrm{Li}_{2} \mathrm{~B}_{12} \mathrm{C}_{2}$ & LiBH & $\mathrm{Li}\left(\mathrm{BH}_{2}\right)$ & $\mathrm{LiBH}_{4}$ & $\mathrm{Li}_{2} \mathrm{~B}_{12} \mathrm{H}_{12}$ \\
\hline $\mathrm{Li}_{3}\left(\mathrm{BH}_{6}\right)$ & $\mathrm{Li}_{3} \mathrm{BN}_{2}$ & $\mathrm{Li}_{2} \mathrm{~B}_{12} \mathrm{Si}_{2}$ & $\mathrm{LiCN}$ & $\mathrm{Li}_{2} \mathrm{CN}_{2}$ \\
\hline $\mathrm{LiMgH}_{3}$ & LiMgN & $\mathrm{Li}_{2} \mathrm{MgSi}$ & $\mathrm{Li}_{12} \mathrm{Mg}_{3} \mathrm{Si}_{4}$ & $\mathrm{LiNH}_{2}$ \\
\hline $\mathrm{Li}_{2} \mathrm{NH}$ & $\mathrm{Li}_{4} \mathrm{NH}$ & $\mathrm{LiN}_{3} \mathrm{Si}_{2}$ & $\mathrm{Li}_{5} \mathrm{~N}_{3} \mathrm{Si}$ & $\mathrm{Li}_{7} \mathrm{~N}_{4} \mathrm{~V}$ \\
\hline $\mathrm{LiNa}_{2} \mathrm{~N}$ & $\mathrm{LiNa}_{5} \mathrm{~N}_{2}$ & $\mathrm{Li}_{2} \mathrm{Na}_{4} \mathrm{~N}_{2}$ & $\mathrm{Li}_{2} \mathrm{NaN}$ & $\mathrm{Li}_{3} \mathrm{Na}_{3} \mathrm{~N}_{2}$ \\
\hline $\mathrm{Li}_{4} \mathrm{Na}_{2} \mathrm{~N}_{2}$ & $\mathrm{Li}_{5} \mathrm{NaN}_{2}$ & $\mathrm{Li}_{3} \mathrm{NaSi}_{6}$ & $\mathrm{Li}_{3} \mathrm{ScN}_{2}$ & $\mathrm{MgAlH}_{5}$ \\
\hline $\mathrm{Mg}\left(\mathrm{AlH}_{4}\right)_{2}$ & $\mathrm{MgAlSi}$ & $\mathrm{MgAl}_{2} \mathrm{Si}_{2}$ & $\mathrm{MgB}_{2} \mathrm{C}_{2}$ & $\mathrm{MgB}_{12} \mathrm{C}_{2}$ \\
\hline $\mathrm{Mg}_{2} \mathrm{~B}_{24} \mathrm{C}$ & $\mathrm{Mg}\left(\mathrm{BH}_{4}\right)_{2}$ & $\mathrm{MgB}_{12} \mathrm{H}_{12}$ & $\mathrm{MgB}_{9} \mathrm{~N}$ & $\mathrm{Mg}_{3} \mathrm{BN}_{3}$ \\
\hline $\mathrm{MgB}_{12} \mathrm{Si}_{2}$ & $\mathrm{MgC}_{4} \mathrm{~N}_{6}$ & $\mathrm{Mg}(\mathrm{NCN})$ & $\mathrm{Mg}\left(\mathrm{NH}_{2}\right)_{2}$ & $\mathrm{MgSiN}_{2}$ \\
\hline $\mathrm{Mg}_{7} \mathrm{TiH}_{16}$ & $\mathrm{~N}_{2} \mathrm{BH}_{7}$ & $\mathrm{~N}_{2} \mathrm{~B}_{10} \mathrm{H}_{18}$ & $\mathrm{~N}_{3} \mathrm{~B}_{3} \mathrm{H}_{6}$ & $\mathrm{~N}_{3} \mathrm{~B}_{3} \mathrm{H}_{12}$ \\
\hline $\mathrm{N}_{4} \mathrm{~B}_{9} \mathrm{H}_{11}$ & $\mathrm{~N}_{4} \mathrm{~B}_{10} \mathrm{H}_{8}$ & $\mathrm{~N}_{4} \mathrm{~B}_{10} \mathrm{H}_{22}$ & $\mathrm{NH}_{3} \mathrm{BH}_{3}$ & $\left(\mathrm{NH}_{4}\right)_{2} \mathrm{~B}_{12} \mathrm{H}_{12}$ \\
\hline$\left(\mathrm{NH}_{2}\right) \mathrm{CN}$ & $\mathrm{NH}_{4} \mathrm{HCN}_{2}$ & $\mathrm{~N}\left(\mathrm{SiH}_{3}\right)_{3}$ & $\mathrm{NaAlH}_{4}$ & $\mathrm{Na}_{3} \mathrm{AlH}_{6}$ \\
\hline $\mathrm{Na}_{5} \mathrm{Al}_{3} \mathrm{H}_{14}$ & NaAlSi & $\mathrm{NaAlSi}_{4}$ & $\mathrm{NaBH}_{4}$ & $\mathrm{Na}_{2}\left(\mathrm{~B}_{10} \mathrm{H}_{10}\right)$ \\
\hline $\mathrm{Na}_{3}\left(\mathrm{BN}_{2}\right)$ & $\mathrm{NaCN}$ & $\mathrm{NaC}_{4} \mathrm{~N}_{3}$ & $\mathrm{Na}_{2} \mathrm{CN}_{2}$ & $\mathrm{Na}_{3} \mathrm{C}_{6} \mathrm{~N}_{9}$ \\
\hline $\mathrm{NaMgH}_{3}$ & $\mathrm{NaN}_{3} \mathrm{C}_{2}$ & $\mathrm{NaNH}_{2}$ & $\mathrm{ScAl}_{3} \mathrm{C}_{3}$ & $\mathrm{Sc}_{2} \mathrm{AlC}$ \\
\hline $\mathrm{Sc}_{3} \mathrm{AlC}$ & $\mathrm{ScB}_{2} \mathrm{C}$ & $\mathrm{ScB}_{2} \mathrm{C}_{2}$ & $\mathrm{Sc}_{2} \mathrm{BC}_{2}$ & $\mathrm{Sc}_{2} \mathrm{~V}_{3} \mathrm{Si}_{4}$ \\
\hline
\end{tabular}




\begin{tabular}{|c|c|c|c|c|}
\hline $\mathrm{SiCN}$ & $\mathrm{SiC}_{2} \mathrm{~N}_{4}$ & $\mathrm{Si}_{2} \mathrm{CN}_{4}$ & $\mathrm{Ti}_{2} \mathrm{AlC}$ & $\mathrm{Ti}_{3} \mathrm{AlC}$ \\
\hline $\mathrm{Ti}_{3} \mathrm{AlC}_{2}$ & $\mathrm{Ti}_{2} \mathrm{AlN}$ & $\mathrm{Ti}_{3} \mathrm{AlN}$ & $\mathrm{Ti}_{4} \mathrm{AlN}_{3}$ & $\mathrm{Ti}_{6} \mathrm{Si}_{2} \mathrm{~B}$ \\
\hline $\mathrm{Ti}_{3} \mathrm{SiC}_{2}$ & $\mathrm{~V}_{12} \mathrm{Al}_{3} \mathrm{C}_{8}$ & $\mathrm{~V}_{5} \mathrm{SiB}_{2}$ & & \\
\hline \multicolumn{5}{|c|}{ Four-element compounds } \\
\hline $\mathrm{AlNC}_{3} \mathrm{H}_{10}$ & $\mathrm{BCH}_{5} \mathrm{~N}_{2}$ & $\mathrm{~B}_{10} \mathrm{C}_{6} \mathrm{H}_{30} \mathrm{~N}_{2}$ & $\mathrm{~B}_{20} \mathrm{C}_{3} \mathrm{H}_{30} \mathrm{~N}_{2}$ & $\mathrm{BC}_{4} \mathrm{KN}_{4}$ \\
\hline $\mathrm{CH}_{3} \mathrm{NH}_{2} \mathrm{BH}_{3}$ & $\mathrm{Ca}_{2} \mathrm{~N}_{2} \mathrm{BH}$ & $\mathrm{Ca}\left(\mathrm{NH}_{2} \mathrm{BH}_{3}\right)_{2}$ & $\mathrm{KAl}\left(\mathrm{NH}_{2}\right)_{4}$ & $\mathrm{~K}_{5} \mathrm{C}_{2} \mathrm{HN}_{4}$ \\
\hline $\mathrm{KCaN}_{3} \mathrm{H}_{6}$ & $\mathrm{~K}\left(\mathrm{HCN}_{2}\right)$ & $\mathrm{K}_{2} \mathrm{LiAlH}_{6}$ & $\mathrm{KLi}_{3}\left(\mathrm{NH}_{2}\right)_{4}$ & $\mathrm{KLi}_{7} \mathrm{~N}_{8} \mathrm{H}_{16}$ \\
\hline $\mathrm{K}_{2} \mathrm{Li}\left(\mathrm{NH}_{2}\right)_{3}$ & $\mathrm{~K}_{2} \mathrm{Mg}\left(\mathrm{NH}_{2}\right)_{4}$ & $\mathrm{~K}_{2} \mathrm{NaAlH}_{6}$ & $\mathrm{~K}_{2} \mathrm{Na}\left(\mathrm{NH}_{2}\right)_{3}$ & $\mathrm{~K}_{3} \mathrm{Si}_{6} \mathrm{~N}_{11} \mathrm{H}_{6}$ \\
\hline $\mathrm{LiAlMg}_{10} \mathrm{H}_{24}$ & $\mathrm{LiAl}\left(\mathrm{NH}_{2}\right)_{4}$ & $\mathrm{Li}\left(\mathrm{B}(\mathrm{CN})_{4}\right)$ & $\mathrm{Li}_{4} \mathrm{BN}_{3} \mathrm{H}_{10}$ & $\mathrm{Li}_{2} \mathrm{Ca}(\mathrm{NH})_{2}$ \\
\hline $\mathrm{LiK}\left(\mathrm{BH}_{4}\right)_{2}$ & $\mathrm{Li}_{2} \mathrm{Mg}(\mathrm{NH})_{2}$ & $\mathrm{Li}\left(\mathrm{NH}_{2} \mathrm{BH}_{3}\right)$ & $\left(\mathrm{Li}\left(\mathrm{NH}_{3}\right)_{4}\right)_{2}\left(\mathrm{~B}_{6} \mathrm{H}_{6}\right)\left(\mathrm{NH}_{3}\right)_{2}$ & $\mathrm{LiNa}_{2} \mathrm{AlH}_{6}$ \\
\hline $\mathrm{LiNa}_{2}\left(\mathrm{NH}_{2}\right)_{3}$ & $\mathrm{Li}_{3} \mathrm{Na}\left(\mathrm{NH}_{2}\right)_{4}$ & $\mathrm{LiSc}\left(\mathrm{BH}_{4}\right)_{4}$ & $\mathrm{Mg}\left(\mathrm{BH}_{4}\right)_{2}\left(\mathrm{NH}_{3}\right)_{2}$ & $\left(\mathrm{NH}_{4}\right) \mathrm{B}(\mathrm{CN})_{4}$ \\
\hline $\mathrm{NaAl}\left(\mathrm{NH}_{2}\right)_{4}$ & $\mathrm{NaB}(\mathrm{CN})_{4}$ & $\mathrm{NaN}_{2} \mathrm{CH}$ & $\mathrm{Si}_{2} \mathrm{C}_{7} \mathrm{H}_{18} \mathrm{~N}_{2}$ & $\mathrm{VC}_{8} \mathrm{H}_{24} \mathrm{~N}_{4}$ \\
\hline \multicolumn{5}{|c|}{ Five-element compounds } \\
\hline $\mathrm{LiAlC}_{4} \mathrm{H}_{16} \mathrm{~N}_{4}$ & $\mathrm{LiSi}_{3} \mathrm{C}_{9} \mathrm{H}_{27} \mathrm{~N}_{2}$ & $\mathrm{Si}_{2} \mathrm{~B}_{2} \mathrm{C}_{12} \mathrm{H}_{37} \mathrm{~N}_{5}$ & & \\
\hline
\end{tabular}

Table A2. Comparison of the experimental and the DFT calculated structural parameters for the 147 compounds listed in Table 1, with all distances in $\AA$ and angles in degrees.

\begin{tabular}{|c|c|c|c|}
\hline \multirow{2}{*}{ Compound } & \multirow{2}{*}{$\begin{array}{l}\text { Space } \\
\text { group }\end{array}$} & \multicolumn{2}{|c|}{ Structural parameters $(\AA$, degree $)$} \\
\hline & & Experimental & Calculated \\
\hline $\mathrm{AlB}_{12}$ & $\mathrm{P}_{4}{ }_{1}{ }_{1} 2$ & $\begin{array}{l}a=10.17 \\
c=14.28\end{array}$ & $\begin{array}{l}a=11.41 \\
c=13.86\end{array}$ \\
\hline $\mathrm{Al}_{4} \mathrm{C}_{3}$ & $\mathrm{R}-3 \mathrm{mH}$ & $\begin{array}{l}a=3.335 \\
c=24.967 \\
\gamma=120\end{array}$ & $\begin{aligned} a & =3.349 \\
c & =25.109 \\
\gamma & =120\end{aligned}$ \\
\hline $\mathrm{Al}_{4} \mathrm{Ca}$ & $\mathrm{I} 4 / \mathrm{mmm}$ & $\begin{array}{l}a=4.354 \\
c=11.18\end{array}$ & $\begin{array}{l}a=4.368 \\
c=11.19\end{array}$ \\
\hline $\mathrm{Al}_{14} \mathrm{Mg}_{13}$ & Im-3m & $a=10.44$ & $a=10.2$ \\
\hline $\mathrm{Al}_{30} \mathrm{Mg}_{23}$ & $\mathrm{R}-3 \mathrm{H}$ & $a=12.825$ & $a=12.787$ \\
\hline $\mathrm{Al}_{23} \mathrm{~V}_{4}$ & $\mathrm{P} 63 / \mathrm{mmc}$ & $\begin{array}{l}a=7.6928 \\
c=17.04 \\
\gamma=120\end{array}$ & $\begin{array}{l}a=7.6809 \\
c=17.04 \\
\gamma=120\end{array}$ \\
\hline $\mathrm{Al}_{45} \mathrm{~V}_{7}$ & $\mathrm{C} 2 / \mathrm{m}$ & $\begin{array}{l}a=25.604 \\
b=7.6213 \\
c=11.081 \\
\beta=128.92\end{array}$ & $\begin{array}{l}a=25.655 \\
b=7.6076 \\
c=11.086 \\
\beta=128.88\end{array}$ \\
\hline $\mathrm{B}_{4} \mathrm{C}$ & $\mathrm{R}-3 \mathrm{mH}$ & $\begin{array}{l}a=5.6 \\
c=12.12 \\
\gamma=120\end{array}$ & $\begin{array}{l}a=7.4 \\
c=8.77 \\
\gamma=120\end{array}$ \\
\hline $\mathrm{B}_{13} \mathrm{C}_{2}$ & $\mathrm{R}-3 \mathrm{mH}$ & $a=5.633$ & $a=5.656$ \\
\hline
\end{tabular}




\begin{tabular}{|c|c|c|c|}
\hline & & $\begin{array}{l}c=12.164 \\
\gamma=120\end{array}$ & $\begin{array}{l}c=12.12 \\
\gamma=120\end{array}$ \\
\hline$\left(\mathrm{B}_{10} \mathrm{H}_{13}\right)_{2}$ & Pbca & $\begin{array}{l}a=10.66 \\
b=10.55 \\
c=14.56\end{array}$ & $\begin{array}{l}a=10.83 \\
b=10.69 \\
c=14.78\end{array}$ \\
\hline $\mathrm{B}_{13} \mathrm{~N}_{2}$ & $\mathrm{R}-3 \mathrm{~m}$ & $\begin{array}{l}a=5.45 \\
c=12.26\end{array}$ & $\begin{array}{l}a=5.49 \\
c=12.41\end{array}$ \\
\hline $\mathrm{C}_{2} \mathrm{Ca}$ & $\mathrm{C} 2 / \mathrm{m}$ & $\begin{array}{l}a=7.2076 \\
b=3.8283 \\
c=7.3677 \\
\beta=107.193\end{array}$ & $\begin{array}{l}a=7.1698 \\
b=3.8325 \\
c=7.4162 \\
\beta=106.961\end{array}$ \\
\hline $\mathrm{C}_{2} \mathrm{~N}_{2}$ & Pcab & $\begin{array}{l}a=6.31 \\
b=7.08 \\
c=6.19\end{array}$ & $\begin{array}{l}a=6.72 \\
b=6.38 \\
c=6.06\end{array}$ \\
\hline $\mathrm{C}_{3} \mathrm{~N}_{4}$ & P-6m2 & $\begin{array}{l}a=4.742 \\
c=6.7205 \\
\gamma=120\end{array}$ & $\begin{array}{l}a=4.766 \\
c=6.4004 \\
\gamma=120\end{array}$ \\
\hline $\mathrm{C}_{5} \mathrm{~N}_{4}$ & $\mathrm{R} 3 \mathrm{cH}$ & $\begin{array}{l}a=9.062 \\
c=11.625 \\
\gamma=120\end{array}$ & $\begin{array}{l}a=8.912 \\
c=11.416 \\
\gamma=120\end{array}$ \\
\hline $\mathrm{C}_{12} \mathrm{~N}_{6}$ & $\mathrm{~Pa}-3$ & $a=10.781$ & $a=10.746$ \\
\hline $\mathrm{CaB}_{4}$ & $\mathrm{P} 4 / \mathrm{mbm}$ & $\begin{array}{l}a=7.1 \\
c=4.14\end{array}$ & $\begin{array}{l}a=7.17 \\
c=4.1\end{array}$ \\
\hline $\mathrm{Ca}_{2} \mathrm{Si}$ & Pnma & $\begin{array}{l}a=7.69 \\
b=4.82 \\
c=9.05\end{array}$ & $\begin{array}{l}a=7.65 \\
b=4.83 \\
c=9.09\end{array}$ \\
\hline $\mathrm{KC}_{8}$ & Fddds & $\begin{array}{l}a=4.92 \\
b=8.51 \\
c=21.39999\end{array}$ & $\begin{array}{l}a=4.97 \\
b=8.61 \\
c=21.36525\end{array}$ \\
\hline $\mathrm{KSi}$ & P-43n & $a=12.62$ & $a=12.72$ \\
\hline $\mathrm{K}_{8} \mathrm{Si}_{46}$ & $\mathrm{Pm}-3 \mathrm{n}$ & $a=10.3$ & $a=10.36$ \\
\hline $\mathrm{LiB}$ & PNMA & $\begin{array}{l}a=6.4 \\
b=3 \\
c=5.6\end{array}$ & $\begin{array}{l}a=6.2251 \\
b=3.0727 \\
c=5.589\end{array}$ \\
\hline LiMg & Im-3m & $a=3.484$ & $a=3.434$ \\
\hline $\mathrm{Li}_{12} \mathrm{Si}_{7}$ & Pnma & $\begin{array}{l}a=8.6 \\
b=19.755 \\
c=14.336\end{array}$ & $\begin{array}{l}a=8.54 \\
b=19.631 \\
c=14.32\end{array}$ \\
\hline $\mathrm{Li}_{13} \mathrm{Si}_{4}$ & Pbam & $\begin{array}{l}a=7.99 \\
b=15.21\end{array}$ & $\begin{array}{l}a=7.902 \\
b=15.022\end{array}$ \\
\hline
\end{tabular}




\begin{tabular}{|c|c|c|c|}
\hline & & $c=4.43$ & $c=4.432$ \\
\hline $\mathrm{Li}_{15} \mathrm{Si}_{4}$ & I-43d & $a=10.69$ & $a=10.6$ \\
\hline $\mathrm{NaB}_{15}$ & Imam & $\begin{array}{l}a=5.847 \\
b=8.415 \\
c=10.298\end{array}$ & $\begin{array}{l}a=5.848 \\
b=8.426 \\
c=10.295\end{array}$ \\
\hline $\mathrm{Na}_{3} \mathrm{~B}_{20}$ & $\mathrm{Cmmm}$ & $\begin{array}{l}a=18.695 \\
b=5.701 \\
c=4.151\end{array}$ & $\begin{array}{l}a=18.636 \\
b=5.693 \\
c=4.158\end{array}$ \\
\hline $\mathrm{Na}_{4} \mathrm{Si}_{4}$ & $\mathrm{C} 2 / \mathrm{c}$ & $\begin{array}{l}a=12.1534 \\
b=6.545 \\
c=11.1323 \\
\beta=118.9\end{array}$ & $\begin{array}{l}a=12.1512 \\
b=6.5632 \\
c=11.1085 \\
\beta=90\end{array}$ \\
\hline $\mathrm{Na}_{8} \mathrm{Si}_{46}$ & $P m-3 n$ & $a=10.19$ & $a=12.31$ \\
\hline $\mathrm{Sc}_{15} \mathrm{C}_{19}$ & $\mathrm{P}-42{ }_{1} \mathrm{c}$ & $\begin{array}{l}a=7.5 \\
c=15\end{array}$ & $\begin{array}{l}a=7.51 \\
c=14.612\end{array}$ \\
\hline $\mathrm{SiB}_{3}$ & Imma & $\begin{array}{l}a=8.3915 \\
b=12.568 \\
c=6.2134\end{array}$ & $\begin{array}{l}a=8.381 \\
b=12.588 \\
c=6.2233\end{array}$ \\
\hline $\mathrm{SiC}$ & F-43m & $a=4.36$ & $a=4.38$ \\
\hline $\mathrm{TiV}$ & Im-3m & $a=3.159$ & $a=3.103$ \\
\hline $\mathrm{V}_{2} \mathrm{~N}$ & P-31m & $\begin{array}{l}a=4.917 \\
c=4.568 \\
\gamma=120\end{array}$ & $\begin{array}{l}a=4.899 \\
c=4.522 \\
\gamma=120\end{array}$ \\
\hline $\mathrm{V}_{5} \mathrm{Si}_{3}$ & $\mathrm{I} 4 / \mathrm{mcm}$ & $\begin{array}{l}a=9.429 \\
c=4.756\end{array}$ & $\begin{array}{l}a=9.393 \\
c=4.715\end{array}$ \\
\hline $\mathrm{Al}\left(\mathrm{BH}_{4}\right)_{3}$ & $\mathrm{Pna}_{1}$ & $\begin{array}{l}a=18.02 \\
b=6.14 \\
c=6.2\end{array}$ & $\begin{array}{l}a=17.99 \\
b=6.12 \\
c=6.2\end{array}$ \\
\hline $\mathrm{Al}_{2} \mathrm{MgC}_{2}$ & P-3m & $\begin{array}{l}a=3.377 \\
c=5.817 \\
\gamma=120\end{array}$ & $\begin{array}{l}a=3.385 \\
c=5.82 \\
\gamma=120\end{array}$ \\
\hline $\mathrm{Al}_{18} \mathrm{Mg}_{3} \mathrm{Ti}_{2}$ & Fd-3ms & $a=14.7875$ & $a=14.775$ \\
\hline $\mathrm{BC}_{2} \mathrm{~N}$ & Pmm2 & $\begin{array}{l}a=2.528 \\
b=2.5024 \\
c=3.5871\end{array}$ & $\begin{array}{l}a=2.56 \\
b=2.5327 \\
c=3.6373\end{array}$ \\
\hline $\mathrm{C}_{2} \mathrm{H}_{4} \mathrm{~N}_{4}$ & $\mathrm{P} 21 / \mathrm{c}$ & $\begin{array}{l}a=3.7913 \\
b=12.4117 \\
c=9.1125 \\
\beta=91.49\end{array}$ & $\begin{array}{l}a=3.6509 \\
b=12.0116 \\
c=9.1886 \\
\beta=91.32\end{array}$ \\
\hline $\mathrm{C}_{2} \mathrm{H}_{18} \mathrm{~N}_{18}$ & P-1 & $a=4.6208$ & $a=4.5006$ \\
\hline
\end{tabular}




\begin{tabular}{|c|c|c|c|}
\hline & & $\begin{array}{l}b=8.5854 \\
c=9.2705 \\
\alpha=108.486 \\
\beta=95.29 \\
\gamma=102.991\end{array}$ & $\begin{array}{l}b=8.415 \\
c=9.1743 \\
\alpha=109.353 \\
\beta=95.17 \\
\gamma=103.087\end{array}$ \\
\hline $\mathrm{C}_{2} \mathrm{~N}_{2}(\mathrm{NH})$ & $\mathrm{Cmc} 2_{1}$ & $\begin{array}{l}a=7.57 \\
b=4.44 \\
c=4\end{array}$ & $\begin{array}{l}a=7.63 \\
b=4.48 \\
c=4.04\end{array}$ \\
\hline $\mathrm{Ca}_{4} \mathrm{Al}_{3} \mathrm{Mg}$ & $\mathrm{Pbcm}$ & $\begin{array}{l}a=6.1792 \\
b=24.2113 \\
c=5.8864\end{array}$ & $\begin{array}{l}a=6.1906 \\
b=24.2483 \\
c=5.9045\end{array}$ \\
\hline CaAlSi & P-6m2 & $\begin{array}{l}a=4.2 \\
c=4.4\end{array}$ & $\begin{array}{l}a=4.21 \\
c=4.41\end{array}$ \\
\hline $\mathrm{Ca}\left(\mathrm{BH}_{4}\right)_{2}$ & F2dd & $\begin{array}{l}a=8.78 \\
b=13.02 \\
c=7.41\end{array}$ & $\begin{array}{l}a=8.75 \\
b=12.94 \\
c=7.37\end{array}$ \\
\hline $\mathrm{CaB}_{12} \mathrm{H}_{12}$ & $\mathrm{C} 2 / \mathrm{c}$ & $\begin{array}{l}a=14.3283 \\
b=7.1642 \\
c=11.017 \\
\alpha=\beta=89.8353 \\
\gamma=122.0687\end{array}$ & $\begin{array}{l}a=14.3069 \\
b=7.1522 \\
c=11.0012 \\
\alpha=\beta=89.8472 \\
\gamma=122.0691\end{array}$ \\
\hline $\mathrm{CaC}_{4} \mathrm{~N}_{6}$ & $\mathrm{C} 2 / \mathrm{c}$ & $\begin{array}{l}a=12.446 \\
b=6.08 \\
c=7.898 \\
\beta=145.2\end{array}$ & $\begin{array}{l}a=12.855 \\
b=6.261 \\
c=7.674 \\
\beta=149.86\end{array}$ \\
\hline $\mathrm{Ca}_{4} \mathrm{~N}_{2}\left(\mathrm{CN}_{2}\right)$ & Pnma & $\begin{array}{l}a=11.44 \\
b=3.58 \\
c=13.84\end{array}$ & $\begin{array}{l}a=11.51 \\
b=3.58 \\
c=13.92\end{array}$ \\
\hline $\mathrm{Ca}_{11} \mathrm{~N}_{6}\left(\mathrm{CN}_{2}\right)_{2}$ & $\mathrm{P} 42 / \mathrm{MNM}$ & $\begin{array}{l}a=14.523 \\
c=3.6083\end{array}$ & $\begin{array}{l}a=14.5506 \\
c=3.6221\end{array}$ \\
\hline $\mathrm{CaSiN}_{2}$ & Pbca & $\begin{array}{l}a=5.123 \\
b=10.207 \\
c=14.823\end{array}$ & $\begin{array}{l}a=5.163 \\
b=10.279 \\
c=14.933\end{array}$ \\
\hline $\mathrm{Ca}_{2} \mathrm{Si}_{5} \mathrm{~N}_{8}$ & Pbca & $\begin{array}{l}a=10.584 \\
b=9.652 \\
c=13.663\end{array}$ & $\begin{array}{l}a=10.6163 \\
b=9.6748 \\
c=13.6685\end{array}$ \\
\hline $\mathrm{Ca}_{5}\left(\mathrm{Si}_{2} \mathrm{~N}_{6}\right)$ & $\mathrm{C} 12 / \mathrm{C} 1$ & $\begin{array}{l}a=9.836 \\
b=6.0519 \\
c=12.757 \\
\beta=100.2\end{array}$ & $\begin{array}{l}a=9.899 \\
b=6.094 \\
c=14.736 \\
\beta=121.155\end{array}$ \\
\hline
\end{tabular}




\begin{tabular}{|c|c|c|c|}
\hline $\mathrm{Ca}_{4} \mathrm{TiN}_{4}$ & P-1 & $\begin{array}{l}a=5.98 \\
b=6.01 \\
c=8.99 \\
\alpha=71.57 \\
\beta=79.47 \\
\gamma=68.26\end{array}$ & $\begin{array}{l}a=6.01 \\
b=6.04 \\
c=9.02 \\
\alpha=71.62 \\
\beta=79.32 \\
\gamma=68.07\end{array}$ \\
\hline $\mathrm{H}_{9} \mathrm{CN}_{9}$ & $\mathrm{P} 2_{1} / \mathrm{c}$ & $\begin{array}{l}a=6.679 \\
b=7.722 \\
c=13.143 \\
\beta=95.44\end{array}$ & $\begin{array}{l}a=6.555 \\
b=7.546 \\
c=12.901 \\
\beta=95.71\end{array}$ \\
\hline $\mathrm{KBH}_{4}$ & Fm-3m & $a=6.71$ & $a=6.69$ \\
\hline $\mathrm{KBH}_{4}$ & $\mathrm{P} 4_{2} / \mathrm{nmc}$ & $\begin{array}{l}a=4.68 \\
c=6.57\end{array}$ & $\begin{array}{l}a=4.71 \\
c=6.61\end{array}$ \\
\hline $\mathrm{KB}_{21} \mathrm{H}_{18}$ & $\mathrm{C} 2$ & $\begin{array}{l}a=12.49 \\
b=7.11 \\
c=16.94 \\
\beta=93.81\end{array}$ & $\begin{array}{l}a=12.71 \\
b=7.22 \\
c=17.04 \\
\beta=94.1\end{array}$ \\
\hline $\mathrm{K}_{2} \mathrm{~B}_{6} \mathrm{H}_{6}$ & Fm-3m & $a=8.839$ & $a=8.897$ \\
\hline $\mathrm{K}_{2}\left(\mathrm{~B}_{10} \mathrm{H}_{10}\right)$ & $\mathrm{P} 121 / \mathrm{n} 1$ & $\begin{array}{l}a=12.8554 \\
b=11.1784 \\
c=6.8227 \\
\beta=93.357\end{array}$ & $\begin{array}{l}a=11.9928 \\
b=9.7475 \\
c=9.0276 \\
\beta=91.93\end{array}$ \\
\hline $\mathrm{K}_{2} \mathrm{~B}_{12} \mathrm{H}_{12}$ & Fm-3 & $a=10.629$ & $a=10.639$ \\
\hline $\mathrm{KC}_{4} \mathrm{~N}_{3}$ & P-1 & $\begin{array}{l}a=8.665 \\
b=8.873 \\
c=3.89 \\
\alpha=86.7 \\
\beta=90.1 \\
\gamma=105\end{array}$ & $\begin{array}{l}a=8.827 \\
b=9.296 \\
c=4.009 \\
\alpha=83.8 \\
\beta=90.9 \\
\gamma=104.3\end{array}$ \\
\hline $\mathrm{KNH}_{2}$ & $\mathrm{P} 2{ }_{1} / \mathrm{m}$ & $\begin{array}{l}a=4.586 \\
b=3.904 \\
c=6.223 \\
\beta=95.8\end{array}$ & $\begin{array}{l}a=4.458 \\
b=3.745 \\
c=6.111 \\
\beta=94.958\end{array}$ \\
\hline$\left(\mathrm{K}\left(\mathrm{NH}_{2}\right)\right)\left(\mathrm{NH}_{3}\right)_{2}$ & $\mathrm{C} 222_{1}$ & $\begin{array}{l}a=6.8386 \\
b=9.9525 \\
c=6.5903\end{array}$ & $\begin{array}{l}a=6.8342 \\
b=9.6806 \\
c=6.5711\end{array}$ \\
\hline $\mathrm{LiAlB}_{14}$ & Imam & $\begin{array}{l}a=5.8469 \\
b=8.1429 \\
c=10.3542\end{array}$ & $\begin{array}{l}a=5.852 \\
b=8.142 \\
c=10.353\end{array}$ \\
\hline $\mathrm{LiB}_{13} \mathrm{C}_{2}$ & Imma & $a=5.6677$ & $a=5.842$ \\
\hline
\end{tabular}




\begin{tabular}{|c|c|c|c|}
\hline & & $\begin{array}{l}b=10.8201 \\
c=8.0399\end{array}$ & $\begin{array}{l}b=9.661 \\
c=8.923\end{array}$ \\
\hline $\mathrm{Li}_{2} \mathrm{~B}_{12} \mathrm{C}_{2}$ & AMM2 & $\begin{array}{l}a=4.706 \\
b=5.318 \\
c=5.318 \\
\alpha=115.798\end{array}$ & $\begin{array}{l}a=4.663 \\
b=5.5534 \\
c=5.5534 \\
\alpha=100.47\end{array}$ \\
\hline $\mathrm{LiBH}$ & PNMA & $\begin{array}{l}a=6.2 \\
b=3 \\
c=6.3\end{array}$ & $\begin{array}{l}a=5.6458 \\
b=3.0758 \\
c=6.5051\end{array}$ \\
\hline $\mathrm{Li}\left(\mathrm{BH}_{2}\right)$ & PNMA & $\begin{array}{l}a=8.1 \\
b=3 \\
c=5.9\end{array}$ & $\begin{array}{l}a=8.3217 \\
b=3.0367 \\
c=5.4851\end{array}$ \\
\hline $\mathrm{Li}_{2} \mathrm{~B}_{12} \mathrm{H}_{12}$ & $\mathrm{~Pa} 3$ & $a=9.5771$ & $a=9.5804$ \\
\hline $\mathrm{Li}_{3}\left(\mathrm{BH}_{6}\right)$ & R3-H & $\begin{array}{l}a=5.1824 \\
\alpha=\beta=\gamma=91.1141\end{array}$ & $\begin{array}{l}a=5.3562 \\
\alpha=\beta=\gamma=94.1637\end{array}$ \\
\hline $\mathrm{Li}_{2} \mathrm{~B}_{12} \mathrm{Si}_{2}$ & Cmce & $\begin{array}{l}a=6.106 \\
b=10.979 \\
c=8.405\end{array}$ & $\begin{array}{l}a=6.118 \\
b=11.012 \\
c=8.43\end{array}$ \\
\hline $\mathrm{LiMgH}_{3}$ & $\mathrm{R} 3 \mathrm{c}$ & $\begin{array}{l}a=4.96 \\
c=13.34\end{array}$ & $\begin{array}{l}a=4.94 \\
c=13.24\end{array}$ \\
\hline $\mathrm{Li}_{2} \mathrm{MgSi}$ & Fm-3m & $a=12.83$ & $a=12.748$ \\
\hline $\mathrm{LiN}_{3} \mathrm{Si}_{2}$ & $\mathrm{Cmc} 2_{1}$ & $\begin{array}{l}a=9.222 \\
b=5.296 \\
c=4.78\end{array}$ & $\begin{array}{l}a=9.277 \\
b=5.329 \\
c=4.812\end{array}$ \\
\hline $\mathrm{LiNa}_{2} \mathrm{~N}$ & $\mathrm{P} 6 / \mathrm{mmm}$ & $\begin{array}{l}a=4 \\
c=4.2 \\
\gamma=120\end{array}$ & $\begin{array}{l}a=4.37 \\
c=3.838 \\
\gamma=120\end{array}$ \\
\hline $\mathrm{LiNa}_{5} \mathrm{~N}_{2}$ & $\mathrm{C}_{2}$ & $\begin{array}{l}a=6.731 \\
b=5.944 \\
c=6.383 \\
\beta=91.18\end{array}$ & $\begin{array}{l}a=6.735 \\
b=5.949 \\
c=6.389 \\
\beta=91.15\end{array}$ \\
\hline $\mathrm{Li}_{2} \mathrm{Na}_{4} \mathrm{~N}_{2}$ & $\mathrm{P} 4 / \mathrm{nmm}$ & $\begin{array}{l}a=3.895 \\
c=6.114\end{array}$ & $\begin{array}{l}a=4.066 \\
c=6.099\end{array}$ \\
\hline $\mathrm{Li}_{2} \mathrm{NaN}$ & $\mathrm{P} 6 / \mathrm{nmm}$ & $\begin{array}{l}a=3.65 \\
c=4.6 \\
\gamma=120\end{array}$ & $\begin{array}{l}a=3.62 \\
c=4.716 \\
\gamma=120\end{array}$ \\
\hline $\mathrm{Li}_{3} \mathrm{Na}_{3} \mathrm{~N}_{2}$ & Pm & $\begin{array}{l}a=3.854 \\
b=3.676 \\
c=6.32 \\
\beta=90.31\end{array}$ & $\begin{array}{l}a=3.853 \\
b=4.208 \\
c=7.272 \\
\beta=89.85\end{array}$ \\
\hline
\end{tabular}




\begin{tabular}{|c|c|c|c|}
\hline $\mathrm{Li}_{4} \mathrm{Na}_{2} \mathrm{~N}_{2}$ & Fm-3m & $a=5.265$ & $a=5.404$ \\
\hline $\mathrm{Li}_{5} \mathrm{NaN}_{2}$ & $\mathrm{P} 4 / \mathrm{mmm}$ & $\begin{array}{l}a=3.965 \\
c=5.504\end{array}$ & $\begin{array}{l}a=3.705 \\
c=5.186\end{array}$ \\
\hline $\mathrm{Li}_{3} \mathrm{NaSi}_{6}$ & Pnma & $\begin{array}{l}a=17.972 \\
b=3.788 \\
c=10.299\end{array}$ & $\begin{array}{l}a=18.021 \\
b=3.804 \\
c=10.331\end{array}$ \\
\hline $\mathrm{MgAl}_{2} \mathrm{Si}_{2}$ & P-3m1 & $\begin{array}{l}a=4.05 \\
c=6.74\end{array}$ & $\begin{array}{l}a=4.08 \\
c=6.69\end{array}$ \\
\hline $\mathrm{MgB}_{12} \mathrm{C}_{2}$ & $\mathrm{C} 2 / \mathrm{c}$ & $\begin{array}{l}a=7.27 \\
b=8.78 \\
c=7.28 \\
\beta=105.33\end{array}$ & $\begin{array}{l}a=7.26 \\
b=8.77 \\
c=7.25 \\
\beta=105.32\end{array}$ \\
\hline $\mathrm{Mg}_{2} \mathrm{~B}_{24} \mathrm{C}$ & P- $4 \mathrm{n} 2$ & $\begin{array}{l}a=8.94 \\
c=5.07\end{array}$ & $\begin{array}{l}a=8.96 \\
c=5.09\end{array}$ \\
\hline $\mathrm{MgB}_{12} \mathrm{H}_{12}$ & $\mathrm{C} 2 / \mathrm{m}$ & $\begin{array}{l}a=11.689 \\
b=8.712 \\
c=6.907 \\
\beta=122.47\end{array}$ & $\begin{array}{l}a=11.687 \\
b=8.711 \\
c=6.905 \\
\beta=122.5\end{array}$ \\
\hline $\mathrm{MgB}_{12} \mathrm{Si}_{2}$ & Pnma & $\begin{array}{l}a=10.98 \\
b=6.11 \\
c=8.36\end{array}$ & $\begin{array}{l}a=11.03 \\
b=6.13 \\
c=8.39\end{array}$ \\
\hline $\mathrm{MgC}_{4} \mathrm{~N}_{6}$ & Pnnm & $\begin{array}{l}a=6.171 \\
b=7.17 \\
c=7.404\end{array}$ & $\begin{array}{l}a=6.443 \\
b=7.289 \\
c=7.429\end{array}$ \\
\hline $\mathrm{Mg}_{7} \mathrm{TiH}_{16}$ & Fm3m & $a=9.564$ & $a=9.341$ \\
\hline $\mathrm{N}_{2} \mathrm{BH}_{7}$ & Pbcn & $\begin{array}{l}a=9.53 \\
b=5.12 \\
c=13.01\end{array}$ & $\begin{array}{l}a=9.768 \\
b=5.237 \\
c=12.672\end{array}$ \\
\hline $\mathrm{N}_{2} \mathrm{~B}_{10} \mathrm{H}_{18}$ & Pnma & $\begin{array}{l}a=18.096 \\
b=7.373 \\
c=7.223\end{array}$ & $\begin{array}{l}a=18.237 \\
b=7.528 \\
c=7.284\end{array}$ \\
\hline $\mathrm{N}_{3} \mathrm{~B}_{3} \mathrm{H}_{6}$ & $\mathrm{P} 4{ }_{3} 2_{1} 2$ & $\begin{array}{l}a=5.428 \\
c=16.279\end{array}$ & $\begin{array}{l}a=5.63 \\
c=17.223\end{array}$ \\
\hline $\mathrm{N}_{3} \mathrm{~B}_{3} \mathrm{H}_{12}$ & $\mathrm{Pbcm}$ & $\begin{array}{l}a=4.403 \\
b=12.21 \\
c=11.227\end{array}$ & $\begin{array}{l}a=4.442 \\
b=12.382 \\
c=11.272\end{array}$ \\
\hline $\mathrm{N}_{4} \mathrm{~B}_{9} \mathrm{H}_{11}$ & $\mathrm{P} 2_{1} / \mathrm{c}$ & $\begin{array}{l}a=8.318 \\
b=5.951 \\
c=19.265 \\
\beta=95.3\end{array}$ & $\begin{array}{l}a=8.611 \\
b=6.263 \\
c=20.044 \\
\beta=94.6\end{array}$ \\
\hline
\end{tabular}




\begin{tabular}{|c|c|c|c|}
\hline $\mathrm{N}_{4} \mathrm{~B}_{10} \mathrm{H}_{8}$ & $\mathrm{C} 2 / \mathrm{c}$ & $\begin{array}{l}a=11.411 \\
b=6.658 \\
c=13.058\end{array}$ & $\begin{array}{l}a=11.945 \\
b=7.373 \\
c=15.268 \\
\alpha=91.09\end{array}$ \\
\hline $\mathrm{N}_{4} \mathrm{~B}_{10} \mathrm{H}_{22}$ & $\mathrm{C} 2 / \mathrm{c}$ & $\begin{array}{l}a=7.7 \\
b=7.7 \\
c=9.772 \\
\alpha=83.872 \\
\beta=83.872 \\
\gamma=82.307\end{array}$ & $\begin{array}{l}a=7.813 \\
b=7.229 \\
c=9.473 \\
\alpha=77.29 \\
\beta=76.99 \\
\gamma=82.3\end{array}$ \\
\hline $\mathrm{NH}_{3} \mathrm{BH}_{3}$ & Pmn21 & $\begin{array}{l}a=5.395 \\
b=4.887 \\
c=4.986\end{array}$ & $\begin{array}{l}a=5.356 \\
b=4.796 \\
c=4.921\end{array}$ \\
\hline$\left(\mathrm{NH}_{4}\right)_{2} \mathrm{~B}_{12} \mathrm{H}_{12}$ & Fm-3 & $a=10.88$ & $a=10.79$ \\
\hline$\left(\mathrm{NH}_{2}\right) \mathrm{CN}$ & Pbca & $\begin{array}{l}a=6.856 \\
b=6.628 \\
c=9.147\end{array}$ & $\begin{array}{l}a=6.726 \\
b=6.597 \\
c=8.916\end{array}$ \\
\hline $\mathrm{NH}_{4} \mathrm{HCN}_{2}$ & $\mathrm{P} 2{ }_{1}{ }_{1} 2$ & $\begin{array}{l}a=6.44 \\
b=6.58 \\
c=7.4\end{array}$ & $\begin{array}{l}a=6.38 \\
b=6.5 \\
c=7.3\end{array}$ \\
\hline $\mathrm{Na}_{5} \mathrm{Al}_{3} \mathrm{H}_{14}$ & $\mathrm{P} 4 / \mathrm{mnc}$ & $\begin{array}{l}a=6.769 \\
c=10.289\end{array}$ & $\begin{array}{l}a=6.7 \\
c=10.2\end{array}$ \\
\hline $\mathrm{NaBH}_{4}$ & Fm-3m & $a=6.15$ & $a=6.02$ \\
\hline $\mathrm{NaBH}_{4}$ & $\mathrm{P}-42{ }_{1} \mathrm{c}$ & $\begin{array}{l}a=4.35 \\
c=5.86\end{array}$ & $\begin{array}{l}a=4.31 \\
c=5.82\end{array}$ \\
\hline $\mathrm{Na}_{2}\left(\mathrm{~B}_{10} \mathrm{H}_{10}\right)$ & $\mathrm{P} 121 / \mathrm{n} 1$ & $\begin{array}{l}a=10.2828 \\
b=13.0218 \\
c=6.6734 \\
\beta=93.754\end{array}$ & $\begin{array}{l}a=9.846 \\
b=12.153 \\
c=8.104 \\
\beta=93.074\end{array}$ \\
\hline $\mathrm{Na}_{3}\left(\mathrm{BN}_{2}\right)$ & $\mathrm{P} 2_{1} / \mathrm{c}$ & $\begin{array}{l}a=5.717 \\
b=7.931 \\
c=7.883 \\
\beta=111.32\end{array}$ & $\begin{array}{l}a=5.737 \\
b=7.966 \\
c=7.9 \\
\beta=111.29\end{array}$ \\
\hline $\mathrm{Na}_{3} \mathrm{C}_{6} \mathrm{~N}_{9}$ & $\mathrm{P} 2_{1} / \mathrm{c}$ & $\begin{array}{l}a=11.048 \\
b=23.381 \\
c=3.516 \\
\beta=97.913\end{array}$ & $\begin{array}{l}a=11.397 \\
b=24.101 \\
c=3.937 \\
\beta=97.913\end{array}$ \\
\hline $\mathrm{Sc}_{2} \mathrm{AlC}$ & P63/MMC & $\begin{array}{l}a=3.2275 \\
c=14.8729 \\
\gamma=120\end{array}$ & $\begin{array}{l}a=3.2849 \\
c=15.0425 \\
\gamma=120\end{array}$ \\
\hline
\end{tabular}




\begin{tabular}{|c|c|c|c|}
\hline $\mathrm{Ti}_{2} \mathrm{AlC}$ & $\mathrm{P}_{3} / \mathrm{mmc}$ & $\begin{array}{l}a=2.97 \\
c=13.22\end{array}$ & $\begin{array}{l}a=3.07 \\
c=13.71\end{array}$ \\
\hline $\mathrm{Ti}_{6} \mathrm{Si}_{2} \mathrm{~B}$ & P-62m & $\begin{array}{l}a=6.802 \\
c=3.338 \\
\gamma=120\end{array}$ & $\begin{array}{l}a=6.777 \\
c=3.312 \\
\gamma=120\end{array}$ \\
\hline $\mathrm{V}_{12} \mathrm{Al}_{3} \mathrm{C}_{8}$ & P63/MCM & $\begin{array}{l}a=5.0882 \\
c=22.9830 \\
\gamma=120\end{array}$ & $\begin{array}{l}a=5.0651 \\
c=22.6375 \\
\gamma=120\end{array}$ \\
\hline $\mathrm{V}_{5} \mathrm{SiB}_{2}$ & $\mathrm{I} 4 / \mathrm{mcm}$ & $\begin{array}{l}a=5.81 \\
c=10.79\end{array}$ & $\begin{array}{l}a=5.774 \\
c=10.762\end{array}$ \\
\hline $\mathrm{AlNC}_{3} \mathrm{H}_{10}$ & $\mathrm{P} 2_{1} / \mathrm{c}$ & $\begin{array}{l}a=5.428 \\
b=9.9076 \\
c=9.9632 \\
\beta=99.254\end{array}$ & $\begin{array}{l}a=5.379 \\
b=11.302 \\
c=10.271 \\
\beta=99.2\end{array}$ \\
\hline $\mathrm{BCH}_{5} \mathrm{~N}_{2}$ & $\mathrm{Pna}_{1}$ & $\begin{array}{l}a=7.973 \\
b=6.445 \\
c=6.976\end{array}$ & $\begin{array}{l}a=7.986 \\
b=6.515 \\
c=7.103\end{array}$ \\
\hline $\mathrm{B}_{10} \mathrm{C}_{6} \mathrm{H}_{30} \mathrm{~N}_{2}$ & $\mathrm{P} 2_{1} / \mathrm{c}$ & $\begin{array}{l}a=8.369 \\
b=16.663 \\
c=11.989 \\
\beta=100.34\end{array}$ & $\begin{array}{l}a=8.586 \\
b=17.002 \\
c=12.249 \\
\beta=100.67\end{array}$ \\
\hline $\mathrm{B}_{20} \mathrm{C}_{3} \mathrm{H}_{30} \mathrm{~N}_{2}$ & $\mathrm{P} 2{ }_{1} 2_{1} 2_{1}$ & $\begin{array}{l}a=10.334 \\
b=10.873 \\
c=17.524\end{array}$ & $\begin{array}{l}a=10.449 \\
b=11.199 \\
c=17.78\end{array}$ \\
\hline $\mathrm{BC}_{4} \mathrm{KN}_{4}$ & $\mathrm{I} 4_{1} / \mathrm{a}$ & $\begin{array}{l}a=6.976 \\
c=14.21\end{array}$ & $\begin{array}{l}a=7.151 \\
c=14.563\end{array}$ \\
\hline $\mathrm{CH}_{3} \mathrm{NH}_{2} \mathrm{BH}_{3}$ & Pnma & $\begin{array}{l}a=11.1 \\
b=6.58 \\
c=4.92\end{array}$ & $\begin{array}{l}a=11.07 \\
b=6.35 \\
c=4.88\end{array}$ \\
\hline $\mathrm{Ca}\left(\mathrm{NH}_{2} \mathrm{BH}_{3}\right)_{2}$ & $\mathrm{C} 121$ & $\begin{array}{l}a=9.10 \\
b=4.37 \\
c=6.44 \\
\beta=93.19\end{array}$ & $\begin{array}{l}a=9.12 \\
b=4.29 \\
c=6.34 \\
\beta=93.1\end{array}$ \\
\hline $\mathrm{KAl}\left(\mathrm{NH}_{2}\right)_{4}$ & $\mathrm{C} 222_{1}$ & $\begin{array}{l}a=10 \\
b=5.8 \\
c=10.14\end{array}$ & $\begin{array}{l}a=10.2 \\
b=5.82 \\
c=10.142\end{array}$ \\
\hline $\mathrm{K}_{5} \mathrm{C}_{2} \mathrm{HN}_{4}$ & $\mathrm{P} 4 / \mathrm{ncc}$ & $\begin{array}{l}a=9.095 \\
c=11.029\end{array}$ & $\begin{array}{l}a=9.225 \\
c=11.202\end{array}$ \\
\hline $\mathrm{KCaN}_{3} \mathrm{H}_{6}$ & $\mathrm{P} 2_{1} / \mathrm{c}$ & $\begin{array}{l}a=6.767 \\
b=11.68\end{array}$ & $\begin{array}{l}a=6.797 \\
b=11.834\end{array}$ \\
\hline
\end{tabular}




\begin{tabular}{|c|c|c|c|}
\hline & & $\begin{array}{l}c=6.624 \\
\beta=106.7\end{array}$ & $\begin{array}{l}c=6.797 \\
\beta=106.82\end{array}$ \\
\hline $\mathrm{K}\left(\mathrm{HCN}_{2}\right)$ & $\mathrm{P} 2{ }_{1}{ }_{1} 2_{1}$ & $\begin{array}{l}a=7.087 \\
b=9.09 \\
c=9.014\end{array}$ & $\begin{array}{l}a=7.229 \\
b=9.172 \\
c=9.158\end{array}$ \\
\hline $\mathrm{K}_{2} \mathrm{LiAlH}_{6}$ & $\mathrm{R}-3 \mathrm{~m}$ & $\begin{array}{l}a=5.62 \\
c=27.4\end{array}$ & $\begin{array}{l}a=5.62 \\
c=27.31\end{array}$ \\
\hline $\mathrm{KLi}_{3}\left(\mathrm{NH}_{2}\right)_{4}$ & $\mathrm{I} 4_{1} / \mathrm{amd}$ & $\begin{array}{l}a=7.238 \\
c=23.956\end{array}$ & $\begin{array}{l}a=8.208 \\
c=23.699\end{array}$ \\
\hline $\mathrm{KLi}_{7} \mathrm{~N}_{8} \mathrm{H}_{16}$ & $\mathrm{I} 4_{1} / \mathrm{a}$ & $\begin{array}{l}a=7.18 \\
c=44.39\end{array}$ & $\begin{array}{l}a=7.678 \\
c=46.545\end{array}$ \\
\hline $\mathrm{K}_{2} \mathrm{Li}\left(\mathrm{NH}_{2}\right)_{3}$ & $\mathrm{P} 42 / \mathrm{m}$ & $\begin{array}{l}a=6.872 \\
c=11.706\end{array}$ & $\begin{array}{l}a=6.866 \\
c=11.726\end{array}$ \\
\hline $\mathrm{K}_{2} \mathrm{Mg}\left(\mathrm{NH}_{2}\right)_{4}$ & $\mathrm{P} 2{ }_{1} / \mathrm{c}$ & $\begin{array}{l}a=7.455 \\
b=7.024 \\
c=13.545 \\
\beta=105.6\end{array}$ & $\begin{array}{l}a=7.255 \\
b=7.255 \\
c=13.626 \\
\beta=105.25\end{array}$ \\
\hline $\mathrm{K}_{2} \mathrm{NaAlH}_{6}$ & $\mathrm{P} 2{ }_{1} / \mathrm{c}$ & $\begin{array}{l}a=5.733 \\
b=5.754 \\
c=8.128 \\
\beta=89.97\end{array}$ & $\begin{array}{l}a=5.743 \\
b=5.7492 \\
c=8.0934 \\
\beta=89.99\end{array}$ \\
\hline $\mathrm{K}_{2} \mathrm{Na}\left(\mathrm{NH}_{2}\right)_{3}$ & $\mathrm{P} 42 / \mathrm{m}$ & $\begin{array}{l}a=7.3514 \\
c=13.1285\end{array}$ & $\begin{array}{l}a=7.5143 \\
c=13.3144\end{array}$ \\
\hline $\mathrm{K}_{3} \mathrm{Si}_{6} \mathrm{~N}_{11} \mathrm{H}_{6}$ & $\mathrm{P}_{4} 32$ & $a=10.789$ & $a=10.797$ \\
\hline $\mathrm{LiAlMg}_{10} \mathrm{H}_{24}$ & P121 & $\begin{array}{l}a=8.9885 \\
b=8.9848 \\
c=4.4846 \\
\beta=89.655\end{array}$ & $\begin{array}{l}a=8.9147 \\
b=8.9417 \\
c=4.4493 \\
\beta=89.65\end{array}$ \\
\hline $\mathrm{Li}\left(\mathrm{B}(\mathrm{CN})_{4}\right)$ & $\mathrm{P} 43 \mathrm{~m}$ & $\begin{array}{l}a=7.8494 \\
\alpha=\beta=\gamma=60\end{array}$ & $\begin{array}{l}a=7.7822 \\
\alpha=\beta=\gamma=60\end{array}$ \\
\hline $\mathrm{Li}_{2} \mathrm{Ca}(\mathrm{NH})_{2}$ & $\mathrm{P}-3 \mathrm{~m} 1$ & $\begin{array}{l}a=3.57 \\
c=5.95\end{array}$ & $\begin{array}{l}a=3.58 \\
c=5.84\end{array}$ \\
\hline $\mathrm{LiK}\left(\mathrm{BH}_{4}\right)_{2}$ & Pnma & $\begin{array}{l}a=7.91 \\
b=4.49 \\
c=13.84\end{array}$ & $\begin{array}{l}a=7.78 \\
b=4.43 \\
c=13.72\end{array}$ \\
\hline $\mathrm{Li}\left(\mathrm{NH}_{2} \mathrm{BH}_{3}\right)$ & Pbca & $\begin{array}{l}a=7.11 \\
b=13.93 \\
c=5.15\end{array}$ & $\begin{array}{l}a=6.92 \\
b=13.52 \\
c=5.07\end{array}$ \\
\hline$\left(\mathrm{Li}\left(\mathrm{NH}_{3}\right)_{4}\right)_{2}\left(\mathrm{~B}_{6} \mathrm{H}_{6}\right)\left(\mathrm{NH}_{3}\right)_{2}$ & $\mathrm{P} 21 / \mathrm{c}$ & $\begin{array}{l}a=7.483 \\
b=11.871\end{array}$ & $\begin{array}{l}a=7.3965 \\
b=11.649\end{array}$ \\
\hline
\end{tabular}




\begin{tabular}{|c|c|c|c|}
\hline & & $\begin{array}{l}c=10.6047 \\
\beta=95.371\end{array}$ & $\begin{array}{l}c=10.4489 \\
\beta=95.21\end{array}$ \\
\hline $\mathrm{LiNa}_{2} \mathrm{AlH}_{6}$ & $\mathrm{P} 21 / \mathrm{c}$ & $\begin{array}{l}a=5.165 \\
b=5.251 \\
c=7.339\end{array}$ & $\begin{array}{l}a=4.777 \\
b=4.715 \\
c=6.613\end{array}$ \\
\hline $\mathrm{LiNa}_{2}\left(\mathrm{NH}_{2}\right)_{3}$ & $\mathrm{P} 4_{2} / \mathrm{m}$ & $\begin{array}{l}a=6.28 \\
c=11.15\end{array}$ & $\begin{array}{l}a=6.17 \\
c=10.90\end{array}$ \\
\hline $\mathrm{LiSc}\left(\mathrm{BH}_{4}\right)_{4}$ & P-42c & $\begin{array}{l}a=6.08 \\
c=12.03\end{array}$ & $\begin{array}{l}a=6.45 \\
c=11.95\end{array}$ \\
\hline $\mathrm{Mg}\left(\mathrm{BH}_{4}\right)_{2}\left(\mathrm{NH}_{3}\right)_{2}$ & Pbca & $\begin{array}{l}a=17.49 \\
b=9.41 \\
c=8.73\end{array}$ & $\begin{array}{l}a=17.73 \\
b=9.35 \\
c=8.68\end{array}$ \\
\hline$\left(\mathrm{NH}_{4}\right) \mathrm{B}(\mathrm{CN})_{4}$ & I $41 / \mathrm{a}$ & $\begin{array}{l}a=7.132 \\
c=14.745\end{array}$ & $\begin{array}{l}a=7.453 \\
c=14.617\end{array}$ \\
\hline $\mathrm{NaAl}\left(\mathrm{NH}_{2}\right)_{4}$ & $\mathrm{P} 2{ }_{1} / \mathrm{c}$ & $\begin{array}{l}a=7.328 \\
b=6.047 \\
c=13.151 \\
\beta=94.04\end{array}$ & $\begin{array}{l}a=6.565 \\
b=6.353 \\
c=15.362 \\
\beta=94.3\end{array}$ \\
\hline $\mathrm{NaB}(\mathrm{CN})_{4}$ & Fd-3mZ & $a=11.68$ & $a=11.874$ \\
\hline $\mathrm{Si}_{2} \mathrm{C}_{7} \mathrm{H}_{18} \mathrm{~N}_{2}$ & $\mathrm{P} 2_{1} / \mathrm{c}$ & $\begin{array}{l}a=9.71 \\
b=11.11 \\
c=11.88 \\
\beta=102.3\end{array}$ & $\begin{array}{l}a=10.143 \\
b=11.599 \\
c=12.422 \\
\beta=103.1\end{array}$ \\
\hline $\mathrm{VC}_{8} \mathrm{H}_{24} \mathrm{~N}_{4}$ & P-1 & $\begin{array}{l}a=8.29 \\
b=12.016 \\
c=13.835 \\
\alpha=75.662 \\
\beta=79.404 \\
\gamma=84.966\end{array}$ & $\begin{array}{l}a=8.637 \\
b=12.503 \\
c=14.479 \\
\alpha=75.89 \\
\beta=79.47 \\
\gamma=85.3\end{array}$ \\
\hline $\mathrm{LiAlC}_{4} \mathrm{H}_{16} \mathrm{~N}_{4}$ & $\mathrm{I} 4_{1}$ & $\begin{array}{l}a=14 \\
c=9.275\end{array}$ & $\begin{array}{l}a=14.128 \\
c=9.571\end{array}$ \\
\hline $\mathrm{LiSi}_{3} \mathrm{C}_{9} \mathrm{H}_{27} \mathrm{~N}_{2}$ & P-1 & $\begin{array}{l}a=8.776 \\
b=9.579 \\
c=21.949 \\
\alpha=100.84 \\
\beta=92.18 \\
\gamma=115.67\end{array}$ & $\begin{array}{l}a=9.077 \\
b=9.875 \\
c=22.544 \\
\alpha=101.16 \\
\beta=91.95 \\
\gamma=115\end{array}$ \\
\hline $\mathrm{Si}_{2} \mathrm{~B}_{2} \mathrm{C}_{12} \mathrm{H}_{37} \mathrm{~N}_{5}$ & $\mathrm{P} 2_{1} / \mathrm{c}$ & $\begin{array}{l}a=15.785 \\
b=11.966 \\
c=11.804\end{array}$ & $\begin{array}{l}a=16.2 \\
b=12.212 \\
c=12.205\end{array}$ \\
\hline
\end{tabular}




\begin{tabular}{|l|l|l|l|}
\hline & & $\beta=102.19$ & $\beta=102.3$ \\
\hline
\end{tabular}

